\title{
EFEITO DA PALHA DE CANA-DE-AÇÚCAR E DO TAMANHO DE TUBÉRCULOS NO DESENVOLVIMENTO DA TIRIRICA (CYPERUS ROTUNDUS L.)
}

MARIA DO CARMO DE SALVO SOARES NOVO

Tese apresentada à Escola Superior de
Agricultura "Luiz de Queiróz",
Universidade de São Paulo, para
obtenção do título de Doutor em
Agronomia, Área de Concentração:
Fitotecnia.

P I R A C I C A B A

Estado de São Paulo - Brasil

Dezembro - 2004 


\section{EFEITO DA PALHA DE CANA-DE-AÇÚCAR E DO TAMANHO DE TUBÉRCULOS NO DESENVOLVIMENTO DA TIRIRICA (CYPERUS ROTUNDUS L.)}

\section{MARIA DO CARMO DE SALVO SOARES NOVO}

Orientador: Prof. Dr. RICARDO VICTÓRIA FILHO

Tese apresentada à Escola Superior de
Agricultura "Luiz
Universidade de Queiróz",
obtenção do título de Doulo, para
Agronomia, Área de Concentração:
Fitotecnia.

P I R A C I C A B A

Estado de São Paulo - Brasil

Dezembro - 2004 
Dados I nt er naci onai s de Cat al ogação na Publi cação ( Cl P) DI VI SÃO DE BI BLI OTECA E DOCUMENTAÇÃO - ESALQI USP

Novo, Maria do Carmo de Salvo Soares

Efeito da palha de cana-de-açúcar e do tamanho de tubérculos no desenvolvimento da tiririca (Cyperus rotundus L.) / Maria do Carmo de Salvo Soares Novo. - - Piracicaba, 2004.

$107 \mathrm{p}$.

Tese (Doutorado) - - Escola Superior de Agricultura Luiz de Queiroz, 2004.

Bibliografia.

1. Brotação 2. Cana-de-açúcar 3. Desenvolvimento vegetal 4. Palha 5. Planta daninha 6. Rizoma 7. Tiririca 8. Tubérculo I. Título

CDD 632.58 
Para os muito amados José, Carolina e Bruno e

Para tia Araci, minha fada e madrinha 


\section{AGRADECIMENTOS}

Ao Prof. Titular Dr. Ricardo Victória Filho pela orientação, paciência e amizade.

Aos Professores da Escola Superior de Agricultura "Luiz de Queiróz" pela dedicação e profissionalismo.

Ao Pesquisador Científico Dr. Robert Deuber, do Instituto Agronômico (IAC), pelo constante apoio e amizade.

Ao Dr. Armando Conagin, pesquisador científico aposentado do IAC, pelo auxílio paciente na elaboração da análise estatística.

Ao Pesquisador Científico Dr. Hipólito Assunção Antonio Mascarenhas, do IAC, pela cobrança diária de resultados.

Ao Fábio Molchanski Longbeck pelo auxílio na condução do experimento e apoio nos momentos cruciais.

Ao técnico de apoio Severino Nogueira que não mediu esforços durante a condução do experimento.

Aos funcionários do Centro Experimental, do IAC, José do Carmo Matias da Silva, José Milton Barbosa dos Santos, Reinaldo Sant'Ana Zoca e Marcos Antonio D’Amico pela colaboração nas coletas de solo e plantas de tiririca.

Ao Setor de Fertilidade do Solo e Nutrição de Plantas do IAC que gentilmente fez as análises de solo. 
Aos colegas do Setor de Irrigação e Drenagem, do IAC, que gentilmente permitiram que o integrador de área foliar fosse utilizado.

Aos funcionários da ESALQ Luis Ferrari e Fernando Trimer de Oliveira pelo auxilio na coleta da palha.

Às secretárias do Departamento de Produção Vegetal da ESALQ Elizabete Sarkis São João, Helena Rodrigues Camargo, Luciane Aparecida Lopes e Maria Célia Rodrigues pelo apoio dado.

Às bibliotecárias da ESALQ Eliana Maria Garcia e Sylvia Zinsly sempre eficientes e dispostas a colaborar.

À Usina Costa Pinto que gentilmente forneceu toda a palha necessária.

Ao Engenheiro Agrônomo Márcio Luiz Adoryan que sempre auxiliou em tudo o que foi possível.

Aos meus superiores hierárquicos do Instituto Agronômico pelas facilidades oferecidas durante o curso.

À Mel Rose Bloom, minha companheira nas longas noites de insônia.

Aos meus pais, sempre presentes, e que me apoiaram em todos os momentos.

Ao CNPq pela concessão da bolsa de estudo

Às demais pessoas que direta ou indiretamente colaboraram na realização deste trabalho. 


\section{SUMÁRIO}

Página

RESUMO

viii

SUMMARY

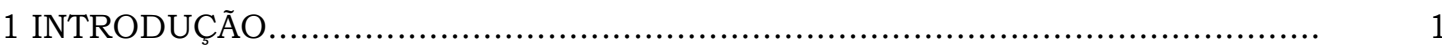

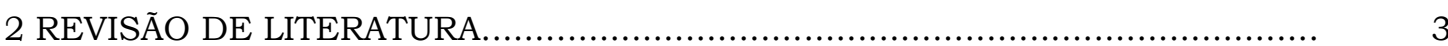

2.1 Aspectos relativos à cana de açúcar........................................... 3

2.2 Aspectos relativos à palha de cana-de-açúcar...................................... 7

2.3 Aspectos relativos à tiririca................................................... 10

2.4 Aspectos relativos à tamanho do dissemínulo.................................. 19

3 EFEITO DA PALHA DE CANA-DE-AÇÚCAR E DO TAMANHO DOS TUBÉRCULOS NA FORMAÇÃO DOS BULBOS BASAIS, RIZOMAS E TUBÉRCULOS DE CYPERUS ROTUNDUS L.

Resumo............................................................................... 29

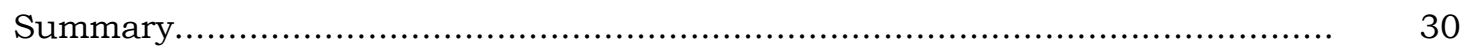

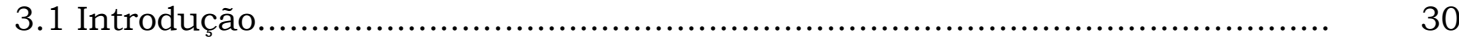



3.3 Resultados e Discussão.................................................... 35

3.4 Conclusões..................................................................... 41

4 EFEITO DA PALHA DE CANA-DE-AÇÚCAR E DO TAMANHO DOS TUBÉRCULOS NA BIOMASSA DAS ESTRUTURAS SUBTERRÂNEAS DE CYPERUS ROTUNDUS L.

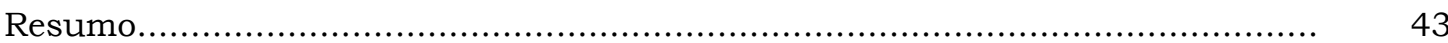

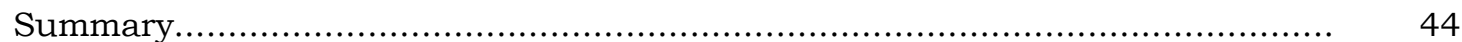

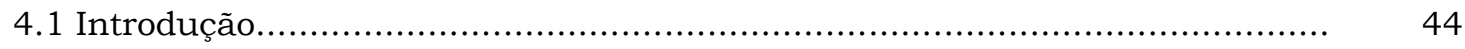

4.2 Material e Métodos................................................................. 45 


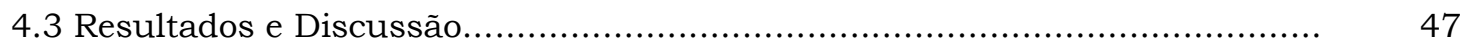

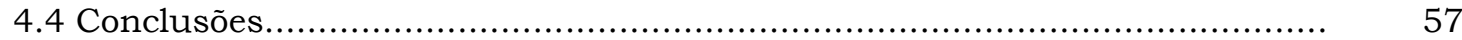

5 EFEITO DA PALHA DE CANA-DE-AÇÚCAR E DO TAMANHO DO TUBÉRCULO NA BROTAÇÃO E NO DESENVOLVIMENTO DA PARTE AÉREA DE TIRIRICA (CYPERUS ROTUNDUS L.)



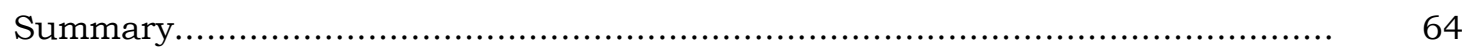

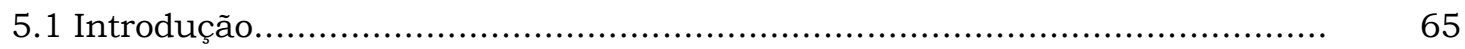



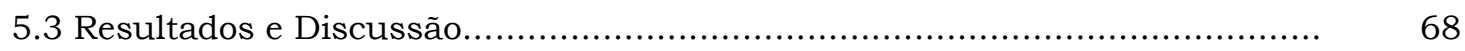

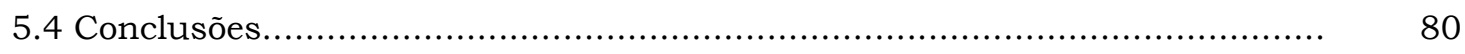

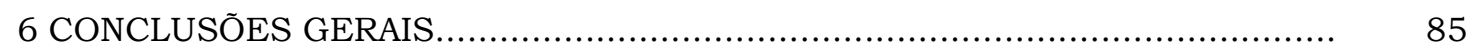

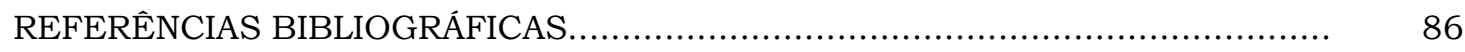




\title{
EFEITO DA PALHA DE CANA-DE-AÇÚCAR E DO TAMANHO DE TUBÉRCULOS NO DESENVOLVIMENTO DA TIRIRICA (CYPERUS ROTUNDUS L.)
}

\author{
Autora: MARIA DO CARMO DE SALVO SOARES NOVO \\ Orientador: Prof. Dr. RICARDO VICTÓRIA FILHO
}

\section{RESUMO}

A mudança do sistema de colheita da cana-de-açúcar com o uso de fogo para a colheita mecanizada, chamada de cana verde ou cana crua, é um processo irreversível, gradativo porém contínuo, previsto na legislação estadual paulista. Um dos pontos críticos no processo produtivo da cana-de-açúcar é a interferência imposta pelas plantas daninhas. A tiririca (Cyperus rotundus L.) é uma das plantas daninhas mais prejudiciais à cultura da cana-de-açúcar entretanto, com a implementação da colheita mecanizada, o desenvolvimento desta planta poderá ser afetado. O objetivo do experimento foi verificar se a adição de palha de cana-de-açúcar poderia afetar o desenvolvimento de plantas de tiririca provenientes de tubérculos de tamanho pequeno $(0,22$ a $0,34 \mathrm{~g})$ e grande $(1,01$ a $1,14 \mathrm{~g})$, plantados em diferentes épocas do ano. $\mathrm{O}$ experimento foi instalado em casa-de-vegetação, em Campinas, SP e disposto em blocos ao acaso com quatro repetições. Tubérculos dormentes de tiririca de tamanho pequeno e grande foram plantados em maio, julho e setembro e adicionou-se sobre o solo palha de cana-de-açúcar RB 855156, nas quantidades correspondentes a 0,0, 5,0, 10,0 e 15,0 t/ha. Em cada época de instalação do experimento, a cada 28 dias até 84 dias, as plantas de tiririca foram avaliadas quanto à altura média, cortadas ao nível do 
solo. As estruturas subterrâneas e aéreas foram separadas nas diferentes estruturas e avaliou-se suas biomassas frescas e secas e a área foliar. De modo geral, o tamanho maior dos tubérculos favoreceu o desenvolvimento da parte subterrânea. O número de brotações emergidas não foi afetado pelo tamanho de tubérculos mas, a altura média, área foliar e as biomassas das folhas e da parte aérea foram maiores quando originadas de tubérculos de tamanho grande. A adição de palha de cana-de-açúcar ao solo afetou mais as plantas originadas de tubérculos pequenos que de grandes. A adição de quantidades crescentes de palha de cana-de-açúcar causou redução no desenvolvimento nas diferentes estruturas subterrâneas, seguindo para todas as variáveis uma equação do segundo grau. Aplicações de quantidades crescentes de palha de cana-de-açúcar causaram diminuição no número de brotações, área foliar e as biomassas frescas e secas das folhas e da parte aérea total. A formação e o desenvolvimento dos rizomas e de tubérculos + bulbos basais, assim como das biomassas fresca e seca de rizomas e fresca de tubérculos + bulbos basais foram maiores no plantio realizados em setembro e menores nos de julho. Verificou-se que, exceto para altura média, o plantio de setembro proporcionou plantas com maior número de brotações, área foliar e biomassas fresca e seca de folhas e da parte aérea total. Para altura média, os melhores resultados foram observados no plantio de maio. Para todas as variáveis analisadas, o plantio de julho apresentou sempre os menores valores. Quanto ao efeito de época de avaliação, verificou-se que para todas as variáveis analisadas foram observados aumentos lineares em função do tempo. 


\title{
EFFECT OF THE SUGAR CANE HARVEST STRAW AND TUBER SIZE ON THE PURPLE NUTSEDGE (CYPERUS ROTUNDUS L.) DEVELOPMENT
}

\author{
Author: MARIA DO CARMO DE SALVO SOARES NOVO \\ Adviser: Prof. Dr. RICARDO VICTÓRIA FILHO
}

\section{SUMMARY}

The change in harvest systems for sugar cane from use of fire to mechanical harvest, is an irreversible process, gradual although continuous, foreseen in the São Paulo State Legislation. One of the critical points in the productive process of sugar cane is the interference imposed by weeds. Purple nutsedge (Cyperus rotundus L.) is one of the most sugar cane crop-damaging weeds, nevertheless with implementation of mechanical harvest technology, which leaves a thick layer straw superior to 20 ton/ha, the development of this plant could be affected. This experiment aimed to verify if the addition of sugar cane straw could affect the development of purple nutsedge plants deriving from tubers of small $(0,20-0,34 \mathrm{~g})$ and large $(1,01-1,14 \mathrm{~g})$ sizes, planted at different times of the year. The experiment was carrIED out in glass house, in Campinas, São Paulo, in randomized blocks with four replicates. Tubers of small and large sizes of purple nutsedge were planted in May, July and September, and RB 855156 sugar cane straw was added, in quantities corresponding to $0,5,0,10,0$ and 15,0 ton/ha. Every 28 days until 84 days after each planting period, the purple nutsedge plants were evaluated as to their average plant height, cut to soil level, and the aerial part was separated from the subterranean. The aerial and subterranean 
structures were separated, and evaluated as to their fresh and dry weights and foliar area. Generally, the larger sized tubers were more favorable to the development of subterranean parts. The number of emerged sprouts was not affected by tuber size; but plant height, foliar area and aerial part weights were larger when originated from large-sized tubers. The addition of sugar cane straw to the soil affected plants derivated from small tuber more than those originated from large one. The addition of growing quantities of straw caused reduction in the development of different kinds of subterranean structures, following for all variables one second-order equation. Application of growing quantities of straw caused a decrease in the sprouts number, area foliar and fresh and dry leaf and total aerial part weights. The formation and development of rhizomes and tubers + basal bulbs, similarly to the fresh and dry rhizome weights of tubers + basal bulbs were larger in September planting and the smallest in July. It was verified that, with exception of average plant height, the September planting generated a larger number of sprouts, foliar area and fresh and dry leaf and total aerial part weights. As for average plant height, the best results were observed at the May planting. For all analyzed variables, the July plantation always presented the smallest values. As to the time of evaluation, it was verified that all variables increased linearly in function of time. 


\section{INTRODUÇÃO}

A mudança do sistema de colheita da cana-de-açúcar do uso de fogo para a colheita mecanizada, chamada de cana verde ou cana crua, é um processo irreversível, previsto na legislação. O uso do fogo tem sido empregado para facilitar o trabalho dos cortadores pois a eliminação dos restos vegetais e de alguns animais que ali se abrigam, incluindo alguns peçonhentos, facilita a operação do corte. Entretanto, esta atividade causa degradação do ambiente por prejudicar a saúde, a segurança e o bemestar da população, principalmente. Essa mudança, embora traga vantagens do ponto de vista ambiental e de saúde pública, se aplicada em curto período de tempo poderia gerar graves desacertos sociais principalmente quanto ao desemprego. A legislação vigente no Estado de São Paulo, que regulamentou o emprego do fogo, estabeleceu que a eliminação da queimada seja feita de maneira gradativa mas contínua, de modo que haja tempo hábil para que a grande maioria dos trabalhadores de baixa escolaridade

seja treinada e possa ser recolocada em outra função dentro do cenário agrícola evitando assim que o êxodo rural aumente.

A colheita da cana-de-açúcar crua deixa uma espessa camada de palha depositada sobre o solo. Velini \& Negrisoli (2000) relataram que a camada de palhada formada sobre o solo pode ser superior a 20,0 t/ha e Abramo Filho et al. (1993) observaram que, em um hectare de cana-de-açúcar, com produção média de 100,0 $\mathrm{t} /$ ha de colmos, resulta em cerca de $15,0 \mathrm{t} /$ ha de palha o que equivale a 6,0 a $6,5 \mathrm{t} / \mathrm{ha}$ de carbono. A adição de palha sobre o solo modifica as condições químicas, físicas e biológicas do ambiente agrícola (Blevins et al., 1971), contribuindo para a melhoria da fertilidade do solo e do desempenho das culturas. Contribuições específicas incluem ainda o controle da erosão, redução do escorrimento superficial, aumento da infiltração, retenção da umidade do solo, aumento no teor de nutrientes e no controle de plantas daninhas (Teasdale, 1996). Essa modificação do ambiente físico e químico do solo afeta também a brotação e o crescimento das plantas e a ação dos herbicidas no controle das espécies daninhas. 
Um dos pontos críticos no processo produtivo da cana-de-açúcar é a interferência imposta pelas plantas daninhas ao competirem com a cultura por nutrientes, água e luz, dificultar o corte e a colheita, diminuindo a qualidade do produto colhido, reduzindo a longevidade do canavial (Quintela et al., 2002) e o rendimento industrial (Mattos et al., 2001). A flora infestante da cultura da cana-deaçúcar é bastante específica e característica (Mascarenhas et al., 1995). Com a implementação da tecnologia da colheita mecanizada deverá ocorrer mudança na composição da comunidade infestante (Azania et al., 2002) pois a cobertura o solo com resíduos vegetais pode interferir em processos como a germinação, o estabelecimento e a reprodução das plantas (Fernandez-Quintanilla, 1988).

A tiririca (Cyperus rotundus L.) é uma das principais infestantes dos canaviais (Holm et al., 1977). Embora o prejuízo que a tiririca causa ao desenvolvimento da planta e, conseqüentemente na produção, seja decorrente da competição exercida durante todo o ciclo, ela é mais prejudicial na fase inicial do desenvolvimento da cultura (Kissmann, 1997) principalmente se permanecer na área de um ano para o outro (Durigan, 1991).

No sistema onde é empregado fogo por ocasião da colheita, foi verificado por Cruz et al. (1993) que a tiririca, em qualquer densidade, prejudicava a brotação da cana-de-açúcar reduzindo a biomassa dos brotos. Nas mesmas condições, Lorenzi et al. (1994) observaram que a tiririca causava inibição de $30 \%$ na intensidade de perfilhamento e redução de $20 \%$ na produção final de colmos. No caso de cana crua, há ainda pouca pesquisa relacionando o efeito da deposição da palha no solo sobre o desenvolvimento da tiririca (Arévalo \& Bertoncini, 1999, Silva et al., 2003 e Correia \& Durigan, 2004).

Os objetivos do experimento foram: verificar se a adição sobre o solo de quantidades diferentes de palha de cana-de-açúcar poderia afetar a formação e a biomassa das estruturas subterrâneas, assim como a emergência e o desenvolvimento da parte aérea de tiririca provenientes de tubérculos de tamanho pequeno e grande, plantados em diferentes épocas do ano. 


\section{REVISÃO DE LITERATURA}

\subsection{Aspectos relativos à cana-de-açúcar}

A cultura da cana-de-açúcar é uma das principais atividades agrícolas do Estado de São Paulo não apenas devido à dimensão da área destinada ao seu cultivo mas também pela quantidade de mão-de-obra agregada à produção. Há muito anos, a cultura da cana-de-açúcar emprega alta tecnologia no preparo do solo, plantio dos toletes e tratos culturais reduzindo os custos operacionais e o tempo necessário para sua realização. Entretanto, para a colheita, o emprego de tecnologia vem sendo introduzido aos poucos. A colheita da cana compreende o corte, o carregamento de toletes e o transporte. As operações de carregamento e transporte, já há algum tempo, utilizam máquinas, o que otimizou o processo, mas o corte, na maioria das regiões, ainda é manual e emprega o fogo para eliminar os restos da cultura. O principal objetivo da queimada é eliminar a palhada da cana-de-açúcar a fim de facilitar o corte e o carregamento e baratear o custo do corte manual.

Há várias décadas, o setor sucroalcooleiro vem enfrentando pressões do segmento ambientalista quanto ao destino dos resíduos industriais, passando pela própria lógica do emprego da monocultura e atualmente, quanto à queimada da palhada (Gonçalves \& Souza, 1998). As organizações ambientalistas centrando a justificativa na qualidade da vida, quanto à saúde humana, o solo e clima vêm pleiteando medidas governamentais restritivas ao uso da queimada.

$\mathrm{Na}$ colheita da cana, a utilização do fogo tem ocasionado diversos problemas. Gonçalves (2002) relatou que a queimada, por ter implicações ecológicas, econômicas e sanitárias, seu emprego tem sido bastante discutido no interior paulista e dado origem a processos jurídicos que visavam coibir sua prática. O emprego do fogo na colheita tem ação biocida em relação à fauna e flora, além de poluir o ambiente liberando para a atmosfera gases primários como monóxido e dióxido de carbono, metano e hidrocarbonetos. É também responsável por muitos acidentes em rodovias. A 
queimada também aumenta a temperatura e diminui a umidade natural dos solos levando à maior compactação e perda de porosidade. Propicia, ainda, a polimerização das substâncias húmicas do solo e causa aumento na perda de nutrientes, seja para a atmosfera - via combustão- seja para as águas por posterior lavagem e lixiviação (Gonçalves, 2002).

Em alguns países produtores de cana-de-açúcar, desde a década de 60 , tem sido discutido o emprego de novas tecnologias na solução deste problema. A evolução da colheita mecanizada no Brasil teve início a partir de 1985 (Ometto, 1994). Guedes \& Ré (2001) acreditam que a intensificação do corte mecanizado foi função do ambiente competitivo criado pelo setor com a saída do governo da cadeia produtiva e à recente legislação estadual que proíbe a queima da cana-de-açúcar.

No Brasil, em 1981, a Lei de Política Nacional do Meio Ambiente no 6938 proibiu a queimada da cana ao ar livre por considerar que esta produzia impactos negativos ao ambiente e à saúde pública. Em primeiro momento o que se pretendeu foi proibir o emprego do fogo como agente despalhador. No Estado de São Paulo, a proibição da queima de cana está regulada pela Lei no 6171 de 4 de dezembro de 1988 e alterada pela Lei $n^{\circ} 8421$ de 23 de novembro de 1993 que trata sobre o uso, conservação e preservação do solo agrícola. Essas leis foram regulamentadas pelo decreto $n^{\circ} .41719$ de 16 de abril de 1997.

Em 6 de agosto de 1997, o decreto no. 42056 estabeleceu o Plano de Eliminação das Queimadas, que regulamentou a prática da queimada (Gonçalves, 2002). Determinou que a redução na queima da cana-de-açúcar na área mecanizável seria efetuada no ritmo de $25 \%$ da área a cada dois anos, sendo exigido um mínimo de redução de $10 \%$ no primeiro ano, o que demandaria oito anos para sua eliminação total e quinze anos para as áreas não mecanizáveis. Por esse decreto, é considerado área não mecanizável aquela com declividade superior a 12\% e/ou com menos de 125 hectares (Gonçalves \& Souza, 1998). A limitação devido à declividade inviabilizaria, no Estado de São Paulo, cerca de $45 \%$ da área plantada com cana (Ustulin \& Severo, 2001). Segundo Gonçalves \& Souza (1998), foi dado o mesmo tratamento de área mecanizável àquelas com 125 hectares para tentar proteger os fornecedores de cana que, em 1998, representavam onze mil produtores e abrangeria 93\% deles. Em 1988, o decreto estadual no 28848 de 1988 proibiu a queima da cana como método de despalha em um raio de um quilometro da área urbana.

$\mathrm{Na}$ ocasião da publicação dessas leis, sabia-se que a mecanização da colheita traria problemas sociais mas admitia-se que o tempo previsto para a eliminação total 
da queimada seria suficiente para a absorção da mão-de-obra. Entretanto, como a economia do país frustou as expectativas do plano, em 1999, o governo do Estado de São Paulo, unido aos usineiros, trabalhadores e fornecedores lançou o Pacto pelo Emprego no Agronegócio Sucroalcooleiro buscando melhores perspectivas para o emprego e produção mas os compromissos firmados na ocasião não se concretizaram (Gonçalves, 2002). Em 2000, a Lei no ${ }^{\circ} 10547$ regulamentada pelo decreto no ${ }^{\circ} .58869$ de 2001, inseriu profundas modificações quanto ao uso agrícola do fogo no Estado de São Paulo. Redefiniu os locais onde o fogo é proibido e os procedimentos e proibições a serem aplicados quando do uso do fogo no ambiente. Previa a eliminação do fogo na colheita no prazo de vinte anos devendo ser realizada de forma gradativa, em conjunto com políticas de reciclagem e aproveitamento da mão-de-obra no setor sucroalcooleiro. Entretanto, o decreto no. 47700 de 11 de março de 2003, prorrogou para 2021 e 2031, respectivamente, a permissão do uso de fogo para áreas mecanizável e não mecanizável.

A colheita mecânica não é só economicamente interessante por permitir padronização, pré-processamento da matéria-prima e maior segurança no processo produtivo mas também por melhorar o controle das atividades de corte e sua compatibilização com o ritmo da indústria, reduzindo os problemas ambientais causados pela queimada e devido à instabilidade da mão-de-obra. Aumenta também em muito a área colhida diariamente. Enquanto um trabalhador braçal colhe, em média, seis toneladas por dia, a máquina pode atingir até 600,0 toneladas/dia (Ustulin \& Severo, 2001). Segundo Arévalo \& Bertoncini (1999), os resíduos melhoram as propriedades fisicas e químicas do solo; conservam e mantém a sua umidade por períodos maiores; aumentam o teor de matéria orgânica; evitam a insolação direta na sua superficie; incrementam microrganismos benéficos; evitam a matocompetição; simplificam o manejo das plantas daninhas e o manejo da cultura é mais econômico.

A colheita da cana crua é realizada preferencialmente de junho até a primeira quinzena de setembro (Tanimoto, 2002) mas para sua aplicação exige modificações técnicas e logísticas que incluem desde o plantio até o recebimento da cana na usina. Requer um bom preparo do solo com sulcos com profundidade regular. O plantio deve ser mais raso e empregar variedades que apresentem crescimento ereto e sem tombamento. O cultivo deve ser feito de tal forma que o terreno fique nivelado, sem falhas, sendo também necessário limpar o terreno sobre o qual as colhedoras irão operar para evitar que tocos, buracos e árvores venham danificar as máquinas (Guedes \& Ré, 2001). Para esses autores é necessário na implantação que o tamanho dos 
talhões seja redimensionado a fim de evitar perda de tempo com manobras adequando também o espaçamento entre as fileiras de maneira a garantir que as máquinas trafeguem com as rodas entre as linhas e não danifiquem as soqueiras.

Para que no momento da colheita haja distribuição da palha de maneira homogênea, a máquina precisa estar bem regulada, com sucção paralela e pouca variação (Ometto, 1994). É também importante que o picador e o distribuidor da palha estejam bem regulados e balanceados, capazes de fracionar a palha e distribuir uniformemente na mesma largura da plataforma da automotriz o que facilitará a operação e possibilitará menor infestação de plantas daninhas.

No entanto, a colheita mecanizada traz algumas desvantagens. Causa alto índice de compactação pois, em alguns casos, a máquina pode pesar mais de dezessete toneladas. Esse fato aliado à pequena superfície de contato compromete a brotação da soqueira, reduzindo a vida útil do canavial (Ustulin \& Severo, 2001). É também necessário alto investimento para a aquisição do maquinário. A colheita mecânica é viável economicamente quando são colhidos mais de 60,0 mil toneladas de cana por safra. Atualmente, poucos são os fornecedores que atingem essa quantidade sendo necessário a formação de consórcios ou terceirizar o serviço da colheita o que inviabilizaria o processo (Ustulin \& Severo, 2001). Reflete ainda na questão do desemprego. O uso da colheita totalmente mecânica ocasionaria uma diminuição de $53 \%$ no total da mão-de-obra utilizada na cultura da cana (Ustulin \& Severo, 2001). Cerca de $71 \%$ dos trabalhadores empregados nessa atividade possuem apenas três anos de escolaridade o que dificultaria a sua recolocação em outros postos de trabalho no meio rural fazendo com que o êxodo rural aumentasse.

Além disso, Gonçalves (2002) cita também como desvantagens:

1) possivel aumento nas perdas de matéria prima, em casos em que a máquina não esteja bem regulada para cortar a cana rente ao solo;

2) aumento das impurezas vegetais, aumentando o custo com transporte, quando a limpeza da palha não for eficientemente realizada pela colhedora;

3) perigo de incêndio na palha, antes, durante e depois da colheita;

4) proliferação de pragas nos resíduos deixados no solo;

5) necessidade de variedade melhor adaptada à nova situação, o que pode exigir alguns anos de estudos e pesquisa;

6) os implementos para cultivo e adubação deverão ser adaptados para que consigam trabalhar no solo com palha. 
Arévalo \& Bertoncini (1999) citam que podem ocorrer prejuízos na brotação de alguns cultivares de cana devido à palhada. Em locais de baixada, o excesso de umidade acumulada no terreno prejudica a brotação e o crescimento da cana e há necessidade de doses adicionais de nitrogênio.

\subsection{Aspectos relativos à palha de cana-de-açúcar}

A mecanização do corte da cana-de-açúcar sem a utilização da queimada modifica as condições do ambiente do solo pois deixa uma camada de palha, que dependendo das condições edafoclimáticas e do cultivar utilizado, pode ser superior a 20,0 t/ha (Correia \& Durigan, 2004). A cobertura morta de resíduos deixada sobre o solo é muito importante no controle de espécies daninhas por influenciar processos como dormência, germinação e mortalidade das sementes e no estabelecimento e reprodução da planta (Fernandez-Quintanilla, 1988 e Trezzi \& Vidal, 2004).

O controle de plantas daninhas pela cobertura morta é atribuída a fatores de natureza física, química e biológica. Os efeitos físicos estão relacionados principalmente à umidade, luminosidade e temperatura do solo (Facelli \& Pickett, 1991; Teasdale \& Mohler, 1993 e Correia \& Durigan, 2004). A cobertura morta que fica sobre o solo reduz a erosão e a evaporação, aumenta a infiltração da água e a retenção da umidade mantendo o solo úmido mesmo durante longo período de estiagem (Reddy, 2003). O impedimento físico causado pela camada de palha exerce ainda diminuição da emergência (Victória Filho, 1985) o que prejudica o desenvolvimento das plântulas de algumas espécies daninhas causando estiolamento e tornando-as suscetiveis à danos mecânicos (Correia \& Durigan, 2004). Reduz também a emergência de plantas originadas de sementes fotoblásticas positivas e daquelas que requerem determinado comprimento de onda ou amplitude térmica para germinar (Correia \& Durigan, 2004). Segundo Almeida (1981), a cobertura morta pode funcionar como um elemento de controle das plantas daninhas, pois um terreno com uma camada uniforme e espessa de resíduos, apresenta uma infestação bastante inferior àquela que se desenvolveria se o mesmo fosse descoberto.

Taylorson \& Borthwick (1969) e Fenner (1980) verificaram que a cobertura morta afetava a comunidade infestante, não só alterando a quantidade de radiação solar incidente mas também a qualidade do comprimento das ondas luminosas, mantendo a temperatura com menos oscilações. Teasdale et al. (1991) verificaram ainda que a cobertura morta impedia fisicamente a emergência das plântulas. Segundo 
Pitelli (1995), o efeito físico dessa cobertura pode reduzir as chances de sobrevivência das plantas daninhas com pouca quantidade de reserva nas sementes. Esta reserva pode não ser suficiente para garantir a sua sobrevivência no espaço percorrido dentro da cobertura do solo, até que tenham acesso à luz e inicie o processo de fotossíntese.

Serve ainda como camada isolante protegendo o solo das variações térmicas diurnas e quando decomposta, enriquece-o com matéria orgânica e nitrogênio. A redução na amplitude térmica da superficie do solo pode interferir de modo decisivo na germinação de muitas espécies. O conhecimento sobre a exigência de maior ou menor amplitude térmica do solo para a emergência da planta daninha constitui-se no modo mais eficiente de controlar a sua germinação no solo. A alternância de temperatura geralmente, acelera a germinação de muitas espécies (Vidal \& Theisen, 1999) diminuindo a preservação e a longevidade do banco de sementes. No caso do uso de cobertura vegetal, Vidal \& Bauman (1996) e Voll et al. (1996), verificaram que para a cultura da soja ocorria redução na infestação de gramíneas anuais. Martins \& Silva (1994) observaram que as sementes de plantas daninhas que encontram-se no solo com cobertura morta, mantiveram-se dormentes por períodos maiores que as situadas nas superficies onde as condições de luz, temperatura e umidade oscilavam com maior freqüencia.

As diferentes espécies que podem ser usadas como coberturas mortas diferem entre si quanto ao tempo que levam para serem decompostas (Rodrigues et al., 1998). Com a decomposição da palha da cana-de-açúcar na superficie do solo, podem ocorrer mudanças na relação $\mathrm{C} / \mathrm{N}$ sendo que cada cultivar apresenta uma relação $\mathrm{C} / \mathrm{N}$ diferente e, dependendo das condições do meio, quanto menor for esse valor, mais rapidamente ela irá se decompor (Silva et al., 2003). Martins et al. (1999) verificaram que a partir da adição de 4,0 t/ha de palha, quanto maior a quantidade aplicada mais difícil tornou-se a decomposição do material.

A cobertura morta pode também liberar substâncias alelopáticas capazes de inibir a germinação das sementes de algumas espécies presentes no solo (Almeida \& Rodrigues, 1985 e Rodrigues et al., 1998). No sistema de produção de cana crua, Martins et al. (1999) relataram que se compostos alelopáticos estiverem presentes na palha, sem a queimada, haverá maior quantidade dessas substâncias sendo liberadas no solo o que poderia favorecer o controle de plantas daninhas mas também causar redução nas brotações da cultura devido a autointoxicação. Segundo Seifert \& Voll (2000), os sintomas dos efeitos alelopáticos mais citados na literatura, provocados pelas coberturas mortas nas culturas são: redução na germinação, falta de vigor 
vegetativo ou morte das plântulas, amarelecimento ou clorose das folhas, redução do perfilhamento e atrofiamento ou deformação das raízes das plantas.

A cobertura morta propicia um ambiente favorável ao desenvolvimento de populações de invertebrados como insetos, moluscos e crustáceos (Rodrigues et al., 1998). Esses organismos interferem na sobrevivência do banco de sementes pois utilizam propágulos como fonte de energia provocando mudanças na comunidade infestante. De maneira geral, diversas espécies de fungos e de outros microrganismos podem também causar deterioração e causar perda de viabilidade nas sementes no solo (Vidal \& Theisen, 1999). Entretanto, como as mudanças são bastante específicas e dinâmicas, podem ou não ser favorecidas pela cobertura morta pois dependem da quantidade de palha e da espessura da camada deixada sobre o solo (Almeida, 1981) e, principalmente, da composição da flora infestante (Azania et al., 2002 e Correia \& Durigan, 2004).

Entretanto, algumas espécies de plantas daninhas ao germinarem, conseguem vencer essa barreira física e se estabelecer no canavial, onde exercerão sua interferência (Hernandez et al., 2001). Quando o solo estiver protegido com camada de resíduos vegetais, as plantas que sobreviverem às dificuldades iniciais de estabelecimento, geralmente, são beneficiadas pela baixa população, cabendo-lhes uma grande porção dos recursos do ambiente, favorecendo seu desenvolvimento e produção de sementes (Theisen \& Vidal, 1999a e b).

A intensidade e o balanço da interferência entre a cultura e a comunidade infestante dependem também da quantidade, da composição e da periodicidade da produção (Silva et al., 2003), de fatores ligados à própria cultura, como por exemplo o cultivar utilizado, da densidade e distribuição dos indivíduos na área cultivada, do tempo de permanência da cobertura morta na área e da época de convivência entre a cultura e a comunidade infestante (Pitelli, 1985). Estas características dependem do clima e do tipo de manejo da área (Azania et al., 2002).

Velini \& Negrisoli (2000) verificaram que em áreas com cobertura de palha pouco espessa e onde há menor crescimento da cultura, ocorre maior infestação de plantas daninhas. Relataram também que mesmo para espécies com alta sensibilidade à cobertura com palha, a supressão da germinação apenas ocorreu quando foram adicionadas quantidades de palha superiores a 10,0 t/ha. Com a implementação da tecnologia da colheita mecanizada da cana deverá ocorrer mudança na composição da comunidade infestante. Vidal \& Theisen (1999) verificaram que com o aumento da quantidade de palha adicionada ao solo diminuía a mortalidade das sementes de 
Brachiaria plantaginea. Segundo esses autores, o tempo necessário para que a mortalidade das sementes atingisse 50\% aumentava na medida em que se incrementava a quantidade de palha na superficie do solo.

Martins et al. (1999) verificaram que a cobertura do solo com diferentes quantidades de palha afetava a germinação de algumas espécies daninhas. Entretanto, para a tiririca a barreira de palha não inibia totalmente a brotação e a formação de parte aérea.

Quintela et al. (2002)1 ${ }^{1}$, citados por Correia \& Durigan (2004), avaliando o efeito físico ou alelopático de extrato aquoso de palha de cana em tiririca, verificaram que o efeito físico da palha foi mais pronunciado que o químico. Silva et al. (2003) observaram que mesmo em áreas com colheita mecanizada, onde a tiririca fica sujeita a grandes quantidades de resíduos da cultura, ela continua ocorrendo com freqüencia relativa elevada.

\subsection{Aspectos relativos à tiririca}

Um dos pontos mais críticos no processo produtivo da cana é a interferência imposta pelas plantas daninhas competindo principalmente por nutrientes, luz e água, por dificultar o corte e a colheita, diminuindo a qualidade do produto colhido e reduzindo o rendimento industrial (Mattos et al., 2001). A flora daninha que infesta a cana-de-açúcar é bastante específica e característica (Mascarenhas et al., 1995) e de acordo com Lorenzi (1982), o que contribuiu para essa especificidade foi o uso continuado de um mesmo herbicida. Durante a fase inicial do crescimento da cana-deaçúcar, ela é sensivel à matocompetição, sendo relatado que o período crítico ocorre nas primeiras doze semanas após o plantio ou da rebrota da soqueira. As perdas de produtividade devido às plantas daninhas são elevadas podendo variar de 10 a mais de $80 \%$ o que torna imprescindivel que seja feito controle ou empregado algum método de manejo (Utiyama et al., 1999). A competição com plantas daninhas resulta em redução na produção de colmos e de açúcar. Entretanto, a intensidade da competição depende de vários fatores como as espécies daninhas presentes, o nivel de fertilidade do solo, o estádio de desenvolvimento do canavial, da época do ano, da duração do período em que se manteve a associação e a própria variedade da cana (Durigan, 1991).

1 QUINTELA, A.C.R. et al. Controle físico e/ou alelopático de três plantas daninhas pelo palhiço de duas variedades de cana-de-açúcar, em condição de casa-de-vegetação. IN: CONGRESSO NACIONAL DA SOCIEDADE DOS TÉCNICOS AÇUCAREIROS E ALCOOLEIROS DO Brasil, 8., 2002, Recife. Anais. Recife: STAB, 2002. p.190-194. 
Segundo Velini \& Negrisoli (2000), em lavouras de cana crua, o efeito da cultura sobre a planta daninha reduzindo a população desta, é pequeno devido ao maior espaçamento entre as linhas. Isso faz com que o fechamento da cultura seja tardio ou não ocorra. Deve-se considerar também a espessura da camada de palha. No caso da cana crua, a capacidade da planta daninha efetivar o processo germinativo no menor tempo é um fator que propiciará a ela maior competitividade. Firbank \& Watkinson (1985) relataram que as diferentes épocas de emergência influenciavam a capacidade competitiva relativa às duas espécies. Se a planta daninha emergir antes da cultura provavelmente utilizará melhor os recursos do meio com maior rendimento que a cultura (Balbinot Júnior et al., 2001). Muitas espécies não germinam se cobertas por uma camada uniforme de palha ou o fazem somente quando pelo menos parte dos resíduos estiverem decompostos. Esse fato causa atrasos na germinação das sementes e na emergência das plântulas reduzindo as populações dessas espécies. Entretanto, esses efeitos dependem do tipo do material empregado na cobertura, de sua distribuição, quantidade e condições climáticas (Reunião de Pesquisa de Soja da Região Sul, 2000).

Segundo Mascarenhas et al. (1995), cerca de 1000 espécies de plantas daninhas habitam o agroecossistema da cana-de-açúcar nas distintas regiões produtoras do mundo afetando a produção, direta ou indiretamente, e influenciando decisivamente na sua produtividade, principalmente em se tratando de espécies perenes, de dificil controle como a tiririca e os capins massambará, colonião e marmelada (Lorenzi et al., 1994).

A tiririca é uma planta daninha que causa sérios prejuízos às culturas, principalmente nas de pequeno porte (Victória Filho, 1985). Embora o prejuízo que a tiririca causa no desenvolvimento da planta e, por conseqüência, na produção seja decorrente da competição exercida durante todo o ciclo, ela é mais daninha na fase inicial do desenvolvimento das culturas (Kissmann, 1997). É uma das principais infestantes dos canaviais (Holm et al., 1977) sendo considerada uma das espécies mais importantes do mundo por sua ampla distribuição, capacidade de competição, longevidade de seus tubérculos (Baruian et al., 1999), agressividade, assim como pela dificuldade em ser controlada ou erradicada (Bendixen \& Nandihalli, 1987; Stoller \& Sweet, 1987; Kissmann, 1997 e Lorenzi, 2000). Kuva et al. (2000) observaram que a cana suporta um pequeno período de convivência inicial com as plantas daninhas sem sofrer interferência na produção. Entretanto, para assegurar a produção, é necessário que seja feito controle da tiririca até, pelo menos, 22 dias após o plantio da cana. 
Ocorre em várias culturas, altitudes, tipos de solo e níveis de umidade e de matéria orgânica mas a sua disseminação é limitada pela sua intolerância à baixa temperatura (Betria \& Montaldi, 1975), não se desenvolvendo em áreas muito sombreadas ou com alto nível de salinidade (Mero-Macias, 1996; Okolli et al., 1997 e Lorenzi, 2000). É um problema sério na maioria das áreas irrigadas principalmente em regiões tropicais e semi-tropicais (Cudney, 1997). Apresenta resistência à condições extremas de calor e seca (Day \& Russell, 1955 e Brighenti et al., 1997a).

Ultimamente, a tiririca tem se tornado um problema maior ainda devido ao uso de herbicidas que controlam a maioria das plantas daninhas anuais e são ineficazes contra ela, aumentando sua infestação; à diminuição do uso de cultivadores, capinas e arações profundas que poderiam expor os tubérculos ao sol; à adoção de métodos mecânicos que podem transportá-la de um local para outro e ao uso intensivo do solo para obter produtividades mais elevadas (Zandstra \& Nishimoto, 1977).

Brighenti et al. (1997a) observaram que a tiririca compete com mais eficiência com culturas de porte baixo pois emerge e cresce mais rapidamente. É também hospedeira de várias espécies de nematóides (Ramirez \& Bendixen, 1982) e de fungos e vírus (Holm et al., 1977). Além de competir com as culturas pelos fatores de crescimento, a tiririca pode também exercer efeito alelopático em outras culturas, reduzindo a brotação e o crescimento, fato este observado em cevada (Friedman \& Horowitz, 1971), em mudas de laranja-azeda (Horowitz, 1973), em tomate (Castro et al., 1983) e em cana-de-açúcar (Kissmann, 1997).

Friedman \& Horowitz (1970) observaram que havia efeito alelopático da tiririca sobre as plantas daninhas grama-seda e capim-massambará. Mostraram também que a redução no crescimento da cevada na presença de tiririca se devia a exsudatos das partes subterrâneas, provavelmente substâncias fenólicas (Friedman \& Horowitz, 1971). Ohira et al (1998) isolaram diversos sesquiterpenos da tiririca e observaram que as diferentes estruturas químicas dependiam da origem da planta. Nishimoto (2000) também relatou que quatro ecotipos distintos de tiririca, provenientes de áreas geográficas diversas apresentavam efeitos alelopáticos diferentes.

A tiririca é uma planta perene, nativa da Índia. Produz numerosas sementes mas estas raramente são viáveis (Justice \& Whitehead, 1946 e Wills, 1975), devido, principalmente, à falta de vigor de suas plântulas (Stoller \& Wax, 1973). As sementes individuais são aquênios sésseis e ovalados (Wills, 1987). Sua reprodução se dá, principalmente, por rizomas e tubérculos.(Cudney, 1997). As plantas apresentam folhas verde-escuras, brilhantes, que se originam na base das hastes. O sistema 
radicular é fibroso.

Apresenta diversos ecotipos cujas diferenças principais ocorrem no número de brotações produzidas a partir de um único tubérculo, no número de folhas por brotação, no comprimento e na largura das folhas e no comprimento da ráquis que suporta a inflorescência. Há também variação na cor das folhas e na biomassa seca e fresca da parte aérea (Wills, 1987). Durigan (1991) relatou que vários ecotipos têm sido identificados com base na constituição química dos tubérculos sendo que estes contém, principalmente, sacarose, glicose e frutose e altas concentrações de amido (Wills, 1975 e Wills \& Briscoe, 1970).

A principal estrutura reprodutiva da tiririca é o tubérculo que produz um ou mais rizomas. Os rizomas são os principais meios pela qual a planta coloniza a área. No início de seu crescimento, os rizomas são brancos, suculentos e tenros tornandose, posteriormente lenhosos e escuros (Wills \& Briscoe, 1970). Podem estender-se para cima, para baixo ou horizontalmente. Aqueles que estendem-se para cima, alcançando a superficie, formam um engrossamento que dará origem ao bulbo basal ou cormo (Chetram \& Bendixen, 1974 e Siriwardana \& Nishimoto, 1987). O bulbo basal produz novos rizomas que crescem horizontalmente sob à superficie do solo produzindo novos bulbos basais e tubérculos dando origem também a parte aérea (Hammerton, 1974). Os rizomas que se estendem horizontalmente ou para baixo, dão origem aos tubérculos que repetem o ciclo para formar outros rizomas em cadeia ou para formar brotações (Wills, 1987). Durante o estabelecimento de uma planta de tiririca, o tubérculo pode permanecer dormente no solo se as condições forem adversas (McGiffen Jr, 1997) ou iniciar seu crescimento (Holt, 1997).

Hauser (1962a) relatou que, em campo, a emergência ocorre seis dias após o plantio; a primeira formação de tubérculo ocorre de dez a dezesseis dias após a emergência da plântula e essas novas plantas formarão mais tubérculos em cerca de 23 dias. É importante observar a precocidade e a rapidez na produção de tubérculo. Hammerton (1974) observou que, em experimento em vaso, novos tubérculos estavam formados dezesseis dias após as brotações terem emergido e, nessa ocasião, a brotação tinha somente seis folhas. Daí até o final do experimento, um novo tubérculo era formado a cada quatro dias. Verificou também que, 51 dias após o plantio, um único tubérculo tinha produzido nove novos tubérculos, nove brotações e quase $0,90 \mathrm{~m}$ de rizomas.

Sob condição de estresse hídrico, os tubérculos dessecam-se rapidamente quando expostos ao sol. Day \& Russell (1955) relataram que quando é realizada uma 
aração profunda e os tubérculos são expostos ao ar, em condição de solo seco, a tiririca é eliminada possibilitando um controle eficiente. Entretanto, esse método de controle só deve ser realizado nos meses em que não ocorre precipitação pois seis dias após a aração, se fosse dada condição para que a tiririca germinasse, 13,7\% dos tubérculos ainda estariam viáveis e apenas dezesseis dias após, nenhum tubérculos seria viável (Day \& Russell, 1955) O maior problema em utilizar esse controle é a necessidade de operações muito freqüentes e que demandam tempo e dinheiro (Victória Filho, 1985). Além disso, segundo Smith \& Mayton (1942), somente são destruídos os tubérculos que ficam na camada superficial do solo. Os que permaneceram mais profundos sobrevivem e servem de fonte para potencial reinfestação.

Horowitz (1972a) avaliou o efeito de podas freqüentes no desenvolvimento da tiririca. Observou que o comprimento do rizoma, o número de tubérculos e o teor de biomassa seca são reduzidos por ocasião da rebrota. A sua capacidade de rebrotar, mesmo em condição de diminuição da biomassa seca, está relacionada com as características do tubérculo, que é um órgão de reserva e, além disso, apresenta várias estruturas em dormência.

Em condições observadas nos Estados Unidos da América do Norte foi verificado que a maioria dos bulbos basais e tubérculos ocorria nos quinze centímetros superiores do solo (Smith \& Mayton, 1942) mas estes já foram observados até a profundidade de 0,40 m (Stoller, 1973). Bhardwaj \& Verma (1968) verificaram na Índia, que $50 \%$ dos tubérculos estavam localizados nos primeiros quinze centímetros, $47 \%$ na profundidade de $0,15-0,30 \mathrm{~m}$ e os $3 \%$ restantes na camadas mais profundas do solo.

Stoller et al. (1972) verificaram em C. esculentus que as brotações emergiam de até $0,30 \mathrm{~m}$ de profundidade. Brighenti et al. (1997b) avaliando em tubos de PVC, no Brasil, a capacidade de emergência de tiririca em profundidades de plantio de 0,20, $0,30,0,50$ e $1,00 \mathrm{~m}$, verificaram que houve emergência em todas as profundidades estudadas.

A tiririca apresenta forte dominância apical e embora esta seja o principal fator que controla a dormência do tubérculo, a umidade do solo, a luz, o teor de oxigênio e a temperatura influenciam o processo de emissão de brotações. Teo et al. (1973) relataram que os tubérculos de cor preta, que são mais velhos, exibem maior grau de dormência, enquanto que os brancos, que são estruturas jovens, facilmente emitem 
brotações. Os tubérculos dormentes têm de uma a treze gemas (Ueki², 1969, citado por Teo et al., 1973) mas somente uma ou duas emitem brotações permanecendo as outras dormentes.

O processo de emissão de brotação, segundo Nishimoto (2000), pode ser caracterizado por duas fases: a quebra da dormência da gema e a elongação do broto. A quebra da dormência da gema ocorre prontamente uma vez que os tubérculos sejam individualizados pois quando unidos pelos rizomas, a maioria apresenta dormência (Bhardwaj \& Verma, 1968 e Siriwardana \& Nishimoto, 1987). Entretanto, além de ser necessário que haja rompimento dos rizomas, as plantas somente vão emitir brotações quando os tubérculos forem expostos à umidade e temperatura adequadas.

Fisher (1971) avaliou o mecanismo de inibição das gemas de C. alternifolius. Sugeriu que o alto nível de ácido giberélico endógeno, associado à deficiência de citocinina causava inibição da gema. Quando ocorria rompimento dos rizomas, a citocinina quebrava a dormência da gema, inibia a dominância apical, induzia a formação de bulbo basal e da brotação da tiririca (Bendixen, 1975). Fisher (1970), estudando o controle dos meristemas internodal intercalar de C. alternifolius, concluiu que para haver inibição das gemas deveria ocorrer declínio no nível de citocinina e de giberelina na haste o que resultava em diminuição na taxa de crescimento internodal. Além do teor de citocinina e de ácido giberélico, a dormência da gema da tiririca era também devida à presença de outros inibidores. Thumbleson \& Kommendahl (1962) verificaram que quando era feita lavagem dos tubérculos antes do início da brotação, ocorria aumento no número de emissões produzidas por tubérculo, sugerindo que o inibidor era hidrossolúvel. Teo et al. (1973) relataram que o ácido salicílico era o principal componente entre os inibidores da folhagem da tiririca mas essa substância não foi encontrada nos tubérculos.

Teo et al. (1973) verificaram que os ácidos giberélico e indól-acético e etefon não apresentaram efeito estimulante na brotação da tiririca. Benziladenina, sempre que presente na estrutura, estimulava a brotação por ter influência no processo de divisão celular, elongação e na mobilização das reservas nutritivas. Há também relatos que a dormência na tiririca poderia ser causada por uma deficiência causada por balanço desfavorável do complexo promotor-inibidor dentro do tubérculo.

Segundo Blanco et al. (1991) parece haver correlação entre o florescimento e o início de dormência dos tubérculos. Após o florescimento, a planta-mãe exerceria uma

\footnotetext{
2 UEKI, K. Studies on the control of nutsedge (Cyperus rotundus L.) on the germination of a
} tuber. Proc. Asian-Pacific Weed Contr. Conf. 2: 355-369, 1969. 
dominância apical sobre os tubérculos formados, impedindo que outras unidades superficiais emergissem (Holm et al., 1977). Em função da dominância apical, o número de tubérculos é sempre maior que o número de brotações, sendo observado por Blanco et al. (1991), que essa proporção variou de um a oito.

Black Junior et al. (1969) e Holt \& Orcutt (1996) classificaram a tiririca como planta $\mathrm{C}_{4}$. É altamente competitiva nos períodos em que a temperatura e a intensidade luminosa são elevadas quando a maioria das culturas tornam-se estressadas, fato que ocorre principalmente no verão (Jackson, 1997).

Há experimentos mostrando que o desenvolvimento da tiririca depende do fotoperíodo, entretanto, a resposta não é muito consistente. De maneira geral, não há concordância entre os diferentes experimentos. Aparentemente, condições de dia longo estimulam a brotação e a produção de rizomas e raízes enquanto que dias curtos, a produção de tubérculos e de inflorescências (Williams, 1982).

Williams et al. (1977) observaram que havia diferença no crescimento da tiririca desenvolvida no verão e no inverno. No plantio realizado em vaso durante o verão, eram produzidos mais tubérculos e estes tinham mais biomassa. No inverno havia menos tubérculos e estes eram mais leves. Diferenças entre as duas épocas foram atribuídas a quantidade de radiação solar disponível sendo que estas foram devidas, em parte, ao menor fotoperíodo observado no inverno.

Berger \& Day 3 (1969) citados por Hammerton (1975b) avaliaram o crescimento da tiririca em fotoperíodos de dez e dezoito horas. Observaram que com dez horas de luz era induzido o florescimento e a produção de tubérculo enquanto que, em fotoperíodos maiores, ocorria inibição destes. Hammerton (1975b) verificou ainda que com o aumento do comprimento do dia, o crescimento dos rizomas ocorria mais depressa, resultando em um maior número de brotações ou de tubérculos. Nessas condições, verificou também que a produção de brotações foi favorecida em detrimento à de tubérculos. Com o aumento do número de brotações, aumentava a produção de fotossintetizados e iniciava a tuberização mesmo que sob condições abaixo do que podia ser considerado ótimo. Segundo Hammerton (1975b), isso sugere que um número mínimo de brotações era necessário para que a tuberização fosse iniciada e/ou que o início desta é dependente de quantidade adequada de fotossintetizados.

Embora o número de brotações e o de tubérculos novos sejam

3 BERGER, G. ; DAY, B.E. Dormancy, growth inhibition and tuberization of nutsedge as affected by photoperiods. Proccedings of First Asian-Pacific Weed-Control Interchange, p.123, 1969. 
significativamente correlacionados, o mesmo não é observado entre número de brotações e biomassa seca total dos tubérculos novos. Hammerton (1975b) sugeriu que no inverno, embora a correlação entre número de brotação e de novos tubérculos formados não fosse alta, o número de brotações determinava o número de tubérculos novos formados. Entretanto, como o suprimento de fotossintetizados é escasso resulta em tubérculos de tamanho pequeno. Isso ocorre porque muitos tubérculos novos não apresentam brotação por estarem dormentes.

Em 1978, Williams verificou que embora a biomassa seca total variasse com o fotoperíodo, a quantidade relativa (como porcentagem da biomassa total) para parte aérea, raízes, rizomas e tubérculos era constante. Segundo Williams (1982), a alocação de biomassa entre as estruturas reprodutivas variava e a tiririca transferia menos de $2 \%$ de sua biomassa para a formação de inflorescência e cerca de $50 \%$ para tubérculos.

Os dados sobre o número de horas necessário para que a tiririca inicie o florescimento têm mostrado resultados discrepantes. Vários autores relataram que o florescimento inicia-se mais precocemente sob dias longos devido à maior disponibilidade de fotossintetizados. Sob condições de dias curtos, quando o crescimento dos rizomas, a produção de parte aérea e a fotossíntese são menores, o florescimento vai ocorrer apenas quando um número mínimo de tubérculos for produzido (Hammerton, 1975c). Foi observado por Hammerton (1975a e b) que o florescimento se dava em comprimento de dias de treze horas e por Williams (1982) em fotoperíodos de dezesseis a dezoito horas. Uma das razões para essa disparidade no número de horas para florescer é a grande variação existente entre populações de diferentes locais.

Entretanto, Betria \& Montaldi (1975), na Argentina, verificaram que não era necessário que houvesse luz para que ocorresse tuberização pois a tiririca foi capaz de repetir seqüências de crescimento em sua ausência. Verificaram também que os rizomas que cresceram a partir de tubérculos plantados em ausência de luz, formavam novos tubérculos apenas quando alcançavam determinada idade. Para os autores, esse fenômeno comum em muitas espécies de tuberosas, é definido como período de incubação. Como acontece com batata [Savic ${ }^{4}$, 1943, citado por Betria \& Montaldi (1975)], quando o tubérculo de origem atinge um determinado estádio de incubação, os rizomas se diferenciam para formar novos tubérculos. Os autores postularam que há substâncias específicas responsáveis pela tuberização como por exemplo, carboidratos

\footnotetext{
${ }^{4}$ SAVIC, V.M. The incubation of potatoes. Sovetsk. Bot., v.6, p.35-41, 1943.
} 
e ácido giberélico (Garg et al., 1967) mas Okasawa \& Chapman (1962) relataram que esse processo também é determinado por diversos outros fatores. Garg et al. (1967) verificaram que a tuberização em $C$. esculentus era favorecida por alta temperatura e baixo teor de nitrogênio. Por outro lado, a formação de brotação era promovida por altos níveis de nitrogênio, fotoperiodo maiores e temperaturas mais elevadas.

Horowitz (1972b) não observou nenhum efeito na tuberização da tiririca em fotoperíodos de dez a catorze horas mas esse encurtamento no número de horas coincidia com o abaixamento da temperatura. Concluiu que o crescimento da tiririca estava mais associado com a temperatura. Entretanto, deve-se considerar que em função da ampla distribuição geográfica da tiririca, a resposta a fotoperíodo e à temperatura pode variar muito refletindo adaptação local dos ecotipos. Nishimoto (2000) verificou também que em função dos ecotipos, a tiririca pode apresentar características alelopáticas, dormência e exigências para emitir brotações, diferentes.

Mudanças na temperatura do ambiente onde as plantas se desenvolvem exercem efeito pronunciado no crescimento e mesmo na produtividade (Pollock, 1990). Segundo Thiesen \& Vidal (1999a e b), a flutuação térmica diária, para muitas espécies de daninhas, pode afetar a germinação dentro da estação de crescimento e inclusive podendo acelerá-la. Foi observado que a brotação das gemas dos tubérculos de tiririca é altamente dependente da temperatura. Wilen et al. (1996a e b) relataram que uma vez que a brotação das gemas da tiririca tenha sido iniciada, a emergência será regulada e poderá ser prevista pelas respostas à temperatura, quando a umidade disponivel for adequada.

Hammerton (1975b) avaliando o desenvolvimento sazonal da tiririca, em vasos, verificou que a temperatura era um fator importante na formação de novos tubérculos e na sua proporção de matéria seca (Black Junior et al., 1969). Wills (1975) observou que acréscimo na temperatura de 18 para $29^{\circ} \mathrm{C}$ aumentava a formação de tubérculos de C. esculentus e Horowitz (1972b) verificou que nas estações quentes, no espaço de um mês, ocorria aumento de dez vezes no número de tubérculos e 3,5 vezes da parte aérea.

Segundo Brighenti et al. (1997b), há correlação entre a temperatura do ar e a rebrota da tiririca. De acordo com esses autores, quando a temperatura do ar se eleva, inicia a fase de rebrota da tiririca e nos períodos de baixo acúmulo térmico, ocorre repouso vegetativo. Horowitz (1972b) sugeriu que era necessário uma temperatura mínima do ar para que houvesse formação de tubérculos de tiririca. Em teste de laboratório, mais de $93 \%$ dos tubérculos sobreviveram por doze semanas a $10^{\circ} \mathrm{C}$ e a 
maioria perdia sua viabilidade a $2^{\circ} \mathrm{C}$ (Stoller, 1973).

A tiririca não ocorre em áreas onde a temperatura média das mínimas é inferior a $-1,1^{\circ} \mathrm{C}$. Bhardwaj \& Verma (1968) verificaram que para as condições da Índia, o período favorável para o desenvolvimento da tiririca é na época chuvosa quando a temperatura média mensal varia de 26 a $31^{\circ} \mathrm{C}$ e a disponibilidade de umidade nos primeiros quinze centímetros do solo é de cerca de $75 \%$. Estudos têm mostrado que a faixa de temperatura ótima para que ocorra brotação é de 25 a $35^{\circ} \mathrm{C}$ (Shamsi et al., 1978) sendo a máxima e a mínima, respectivamente, 45 e $13^{\circ} \mathrm{C}$ (Miles et al., 1996).

Miles et al. (1996) compararam a resposta da tiririca à temperatura constante e alternada e determinaram o efeito da amplitude da oscilação térmica e o tempo de exposição à temperatura máxima. A brotação da tiririca foi mais rápida e completa com temperaturas alternadas que com constante. Aumento da flutuação de temperatura de 0 para $6^{\circ} \mathrm{C}$, por doze horas diárias, aumentou linearmente o total de tubérculos que brotaram. Exposição à luz por 30 minutos diários à alta temperatura forneceu quase o mesmo nível de brotação que o ciclo de alternância de doze horas de luz.

\subsection{Aspectos relativos ao tamanho do disseminulo}

As sementes, dissemínulos ou propágulos de uma planta daninha são estruturas reprodutivas que dão origem à novos indivíduos. Estão distribuídos nas diversas camadas do solo e, se forem viáveis e/ou não estiverem dormentes, após germinarem e estabelecerem novas plantas estas vão competir com as culturas por água, luz e nutrientes (Stoller \& Wax, 1973). A germinação, o estabelecimento, o desenvolvimento e a produção de uma planta são afetados por diversos fatores sendo um deles o tamanho do dissemínulo (Wulff, 1986a).

Há controvérsia se o tamanho da estrutura reprodutiva da planta afeta ou não as diversas fases do seu crescimento. Tem sido observado que para a maioria dos experimentos realizados em casa-de-vegetação, há efeito do tamanho dos dissemínulos mas em campo, não. A variabilidade no tamanho do dissemínulo pode afetar também a fase de dispersão, a porcentagem de dissemínulo germinante, a taxa em que esta ocorre (Weis, 1982), as relações dissemínulo-água e a capacidade de emergir à diferentes profundidades de plantio (Black, 1956) podendo, potencialmente, afetar diversos aspectos no estabelecimento da plântula (Harper et al., 1970).

Há grande variação no tamanho dos dissemínulos devido à forças adaptativas 
das diferentes partes do ciclo reprodutivo da planta. Tanto dentro como entre espécies, o tamanho maior do dissemínulo tem sido associado a habitats menos perturbados, com melhor disponibilidade hídrica (Baker, 1972 e Schimpf, 1977), com menor altitude (Baker, 1972) e maior latitude (McWilliams et al., 1968). Temme (1986) relatou que o tamanho da semente é o aspecto reprodutivo da planta menos variável mas não é necessariamente constante tanto entre como dentro de plantas (Wilbur, 1977; Schaal, 1980 e Pitelka et al., 1983). Temme (1986) observou também que o padrão de germinação de uma espécie pode estar correlacionado com o tamanho mas não é causado por variação no tamanho da semente. A variação no tamanho da semente pode ocorrer por incapacidade das plantas em produzir todas os dissemínulos de um mesmo tamanho por problema espacial ou fisiológico associado à posição do fruto na planta ou da posição da semente dentro do fruto (Schaal, 1980 e Waller, 1982) ou no número de sementes produzidas em cada fruto (Ruiz de Clavijo, 2001). Pode também ser devido à mudanças temporais no ambiente físico ou fisiológico da planta (McWilliams et al., 1968). Fatores que induzem variação no tamanho do propágulo estão também relacionados com mudanças nas fontes de nutrientes, de água e de ambiente onde a planta-mãe foi exposta, e também com o declínio sazonal e a densidade das plantas (Ruiz de Clavijo, 2001). Weis (1982) e Gross (1984) observaram que havia diferença na habilidade competitiva e Black (1956, 1957a e b e 1958) e Schaal (1980) no crescimento e na sobrevivência na fase de plântula devido ao tamanho dos dissemínulos

Salisbury ${ }^{5}$ (1942), citado por McWilliams et al. (1968), verificou que as espécies tanto podem utilizar o material de reserva para produzir muitas sementes pequenas como poucas de tamanho grande. Entretanto, Wulff (1986a) verificou que para Desmodium paniculatum não foi observado correlação entre biomassa média por planta e número total de sementes produzido por planta.

Há diversos artigos científicos relatando as relações entre tamanho das sementes e o desenvolvimento das plantas, entretanto foram encontrados poucos que avaliassem o mesmo para Cyperus rotundus L quanto aos aspectos de germinação, emergência e desenvolvimento da planta.

Hammerton (1975b) enfatizou que o tamanho do tubérculo de tiririca tem influência no início de seu crescimento. Verificou ainda que tubérculos de tamanho grande tem mais gemas e mais biomassa que os pequenos. Não foram observadas evidências de competição entre tubérculos novos e os de origem por fotossintetizados.

5 SALISBURY, E. The reproductive capacity of plants. 1942, Londres: G. Bell. 224p. 
Também não foi observada nenhuma correlação entre o aumento de biomassa seca do tubérculo de origem e o número de brotação e produção de biomassa seca. Esse fato sugere que o tubérculo de origem não é simplesmente um dreno para que qualquer excesso de fotossintetizados mas que a recolocação de reservas do tubérculo de origem tem alta prioridade.

Black (1958) apontou como uma vantagem competitiva o maior tamanho da semente. Para ele, uma semente de tamanho grande, que possui mais nutrientes armazenados, tem vantagem seletiva em locais onde a estação para crescimento da planta é curta como nos países de latitude mais ao norte. Weis (1982) e Stock et al. (1990) relataram que a vantagem do dissemínulo ser de tamanho grande está associado com sua habilidade em prover com a energia e os nutrientes necessários para que a planta se estabeleça com sucesso. A energia inicial e os nutrientes armazenados no dissemínulo permitem que a planta cresça através do solo, liteira ou camada de cobertura vegetal para ambientes com maior intensidade luminosa.

Leishman \& Westoby (1994) verificaram que plântulas originadas de dissemínulos de tamanho grande são, geralmente, maiores e mais robustas por curto período de tempo após a germinação. Mostrou também que no campo, as plântulas menores e menos robustas são mais vulneráveis a serem removidas do solo por um simples impacto da água pois a variabilidade na intensidade da chuva e as condições de umidade do solo afetam a capacidade de plântulas se estabelecerem no solo. Muitas espécies apresentam adaptações nas suas estruturas reprodutivas para germinar apenas em condições favoráveis.

Temme (1986) sugeriu que a variação no tamanho do dissemínulo dentro de uma planta representa uma adaptação. Essa variação está envolvida com resposta a fatores ambientais. A germinação de um dissemínulo pode variar com as condições ambientais a qual à planta-mãe foi exposta (Wulff, 1986a) pois esta é substancialmente controlada pela temperatura, pela flutuação da temperatura e pelo potencial hídrico do meio e, a emergência, por todos estes fatores, assim como pela profundidade de plantio (Alm et al., 1993).

Aumento na temperatura durante o crescimento da planta, diminui a disponibilidade por nutriente e água e a redução no fotoperíodo reduz a biomassa média da semente. Figueiredo \& Vieira (1970) verificaram que o tamanho médio das sementes de feijão pode ser influenciado pela temperatura, umidade, fertilidade do solo, espaçamento e época de plantio. Black (1957c) observou que a biomassa seca de plantas de trevo no período inicial do crescimento vegetativo era altamente dependente 
do tamanho da semente. Também foi observado que plântulas provenientes de sementes maiores têm maior extensão de raiz e portanto são mais tolerantes à seca (Wulff, 1986b).

Para a tiririca foi observado que há correlação entre o número de brotações e o de tubérculos novos mas não para número de brotações e biomassa seca total dos tubérculos novos. Hammerton (1975b) sugeriu que no inverno, embora a correlação entre número de brotação e de novos tubérculos formados não seja alta, o número de brotações determina o número de tubérculos novos formados. Entretanto, como o suprimento de fotossintetizados é escasso resulta em tubérculos de tamanho pequeno. Isso ocorre porque muitos tubérculos novos não apresentam brotação por estarem dormentes.

A maioria das plantas daninhas apresenta sementes de tamanho pequeno quando em comparação com as culturas o que seria uma desvantagem no início de seu crescimento. Seibert \& Pearce (1993) compararam as características morfológicas e de crescimento de plantas daninhas com culturas para determinar como as primeiras que tem sementes pequenas poderiam competir. Verificaram que as plantas daninhas tinham maior taxa de crescimento porque grande parte da sua biomassa era devotada a formação de folhas e apenas pequena parte era destinada às raízes. Além disso, plantas daninhas eram capazes de desenvolver comprimento médio de raízes maiores, apresentando também aumento no diâmetro das raízes pequenas e maiores taxas de crescimento destas.

Hopper et al. (1979) e Schaal (1980) observaram que disseminulos grandes apresentavam maior porcentagem e taxa de germinação. Gross (1984) relatou que além do tamanho dos dissemínulos, a emergência e, subseqüentemente, os padrões no estabelecimento das plântulas podem ser afetados pelo tempo para emergir, a forma de crescimento das plântulas, a taxa de crescimento relativo e a relação entre estes e a cobertura do solo.

Edwards Junior \& Hartwig (1971) verificaram que, sob condição de casa-devegetação, sementes de soja de tamanho pequeno e médio germinavam mais rapidamente e apresentavam maior desenvolvimento do hipocótilo e da radícula que as de sementes grandes. Entretanto, esse fato varia de espécie para espécie. Pandey \& Dubey (1988) verificaram que os aquênios de tamanho grande da planta daninha Parthenium hysterophorus L. apresentavam maior germinação que os de tamanho pequeno. Mostraram também que a influência maior era da fonte do dissemínulo pois dependendo do local de origem da planta, essa poderia apresentar maior porcentagem 
de aquênios pequenos ou grandes. Stoller et al. (1972) verificaram que não havia diferença significativa na porcentagem de germinação de tubérculos de C. esculentus que apresentavam biomassa fresca de 61, 128, 201 e 294 mg de tubérculo. Entretanto, a biomassa seca do material produtivo foi significativamente correlacionada com a biomassa fresca do tubérculo que foi formado.

Burris et al. (1973) observaram que, sob condição de laboratório, as sementes de tamanho grande exibiam maior porcentagem de emergência e área foliar, mas, as plantas originadas de dissemínulos menores exibiam maiores taxas fotossintéticas. Os autores verificaram que a menor fotossintese observada em plântulas originadas de dissemínulos grandes pode ser devida a menor demanda por fotossintetizados causada pela maior quantidade de energia existente na semente. Entretanto, no campo, as sementes grandes apresentaram maior porcentagem de emergência, área foliar e altura.

Lafond \& Baker (1986) observaram que plantas de trigo originadas de sementes pequenas emergiram mais rapidamente mas acumularam menos biomassa seca da parte aérea que as originadas das grandes. Costa et al. (1973) verificaram que sementes de soja pequenas (10,2 g/100 sementes) apresentaram plantas com menor estatura e com a primeira vagem mais próxima do solo que as de tamanho médio e grande o que prejudicava a produção. Contudo, os efeitos parecem depender da variedade pois alguns materiais têm influencia na população, na altura e na produção enquanto que outros, não (Cazetta et al., 1995).

O tamanho do tubérculo da tiririca influencia o início do crescimento. Foi demonstrado por Hammerton (1975b) que o efeito do tamanho do tubérculo, persiste por período superior a 45 dias, quando novos tubérculos e possivelmente inflorescências estarão presentes. O tubérculo inicial tem função importante no crescimento da tiririca atuando não somente como fonte inicial de reserva mas também como uma fonte posterior no crescimento e como dreno para os fotossintetizados (Hammerton, 1974).

O tamanho do tubérculo da tiririca reflete também o tempo disponivel para que ocorra seu desenvolvimento. $\mathrm{O}$ início do florescimento precoce pode ser um fator que contribui para que a biomassa do tubérculo seja pequena assumindo que há competição entre os diferentes órgãos por fotossintetizados. Hammerton (1974) verificou que tubérculos de tamanho grande tem mais gemas e mais biomassa seca por gema que os pequenos. 
Há controvérsia se tamanho do propágulo afeta o vigor e posteriormente a produção da planta. O vigor do dissemínulo é que determina o potencial para que ocorra emergência rápida, uniforme e para que a plântula se desenvolva sob as mais diferentes condições de campo (Webster \& Magruder, 1938). Baixo vigor pode resultar em germinação mais lenta, menor taxa de crescimento da plântula e maior suscetibilidade à patógenos do solo, estande menor e produções mais baixas (Ratnayaki \& Shaw, 1992). Evans \& Bhatt (1977) verificaram que havia correlação entre o tamanho de semente, o teor de proteína o vigor de plântulas de trigo aos vinte dias após o plantio.

Stoller et al. (1972) verificaram que o tamanho do tubérculo de C. esculentus influenciava o vigor das plântulas. Como o vigor da plântula é um fator determinante na atividade do herbicida, deve haver grande variação na resposta a esses produtos entre tubérculos de tamanho diferente. Também deve-se considerar que há perda no vigor da brotação e que este acompanha a perda de energia dos tubérculos durante cada germinação sucessiva. Porém, plantas que emergem após as brotações anteriores terem sido eliminadas devem ser mais fáceis de controlar que a brotação original devido à perda de energia do tubérculo e a subseqüente redução no vigor da planta.

Seibert \& Pearce (1993) verificaram que variação no tamanho da parte aérea ou do sistema radicular afeta a capacidade da planta em assegurar fontes de recursos para seu desenvolvimento. Plântulas maiores apresentam vantagem durante o início da competição e este fato está linearmente correlacionado com a biomassa da semente (Fenner, 1983).

Admitindo-se que uma mesma espécie com dissemínulos de tamanhos diferentes apresentem taxas de crescimento relativo iguais, propágulos com maior biomassa podem propiciar maior crescimento, e em culturas, maior produtividade (White \& Gonzáles, 1990). Wulff (1986a) observou que aumento da temperatura durante o estádio de crescimento das plantas reduz a disponibilidade de nutrientes e de água e associado ao encurtamento do fotoperíodo, diminui a biomassa média de sementes.

Hammerton (1967a) verificou que em uma mesma população da planta daninha Polygonum lapathifoium, a biomassa média das sementes variava consideravelmente entre as diferentes épocas de colheita. A data de plantio é, aparentemente, um fator que influencia a biomassa da semente pois o comprimento do dia, a intensidade luminosa e a temperatura durante o crescimento e o desenvolvimento variam no tempo. Mas para P. persicaria também devem ser considerado as diferenças genéticas 
da populações e dos métodos de cultivos a que está sujeita a área em questão. Observou também que havia grande variação entre plantas e entre inflorescência quanto à biomassa de semente dentro das populações. Também a nutrição e a época de plantio influenciavam a biomassa de sementes, o que contribuia para sua variabilidade (Hammerton, 1967b).

Black (1956, 1957a) demonstrou que, em estudo realizado em vaso, o aumento na biomassa seca durante a fase inicial do crescimento do trevo subterrâneo foi bastante dependente do tamanho da semente. Em outro trabalho, Black (1957b) observou que a biomassa seca era proporcional ao tamanho da semente no início da fase de crescimento mas posteriormente esta era quase idêntica. Explicou a diferença na taxa de crescimento em termos de índice de área foliar e interceptação de energia luminosa incidente. Lawson \& Rossiter (1958) compararam o efeito do tamanho de sementes de trevo subterrâneo quando semeado em biomassa igual de sementes viáveis por unidade de área e verificaram que não houve efeito na taxa de crescimento.

O plantio de sementes ou de dissemínulos em maiores profundidades, dependendo do tipo de solo, pode afetar seriamente o estande. Stoller \& Wax (1973) verificaram que havia correlação significante entre tamanho de semente e a profundidade máxima para emergir sendo observado que plantas originadas de dissemínulos maiores emergem de maiores profundidades.

Stoller \& Wax (1973) mostraram que havia correlação entre a biomassa de dissemínulos e a profundidade de enterrio destes. Beveridge \& Wilsie (1959) observaram que embora sob condição de casa-de-vegetação, a emergência das plântulas de alfafa era diminuída em função da profundidade de plantio, o mesmo não se repetia no campo. Os dissemínulos com maior biomassa emergem de profundidades maiores pois há maior disponibilidade hídrica (Leishman \& Westoby, 1994). Erickson (1946) e Rogler (1954) trabalhando com trigo e alfafa, respectivamente, observaram que com o aumento da profundidade de plantio, as plantas originadas de sementes grandes levavam vantagem sobre as pequenas no estabelecimento das plantas. Por sua vez, Black (1956) verificou que para o trevo subterrâneo, a profundidade de plantio com qualquer tamanho de semente não afetava a biomassa seca, a área foliar e o número de folhas.

Eames (1949) relatou que tubérculos de tiririca de tamanho pequeno, que eram encontrados em maior profundidade no solo, apresentavam plantas com menor crescimento. Siriwardana \& Nishimoto (1987) avaliando a distribuição de propágulos 
de tiririca no perfil do solo verificaram que nas camadas mais superficiais os tubérculos eram maiores e apresentavam maiores porcentagens de biomassa seca.

Reader (1993) verificou que a cobertura do solo reduzia mais a emergência de plântulas originadas de sementes pequenas que de grandes. Entretanto, a remoção da cobertura do solo aumentava significativamente a emergência tanto de plântulas originadas de sementes pequenas como de grandes. O sombreamento pode inibir a germinação enquanto que a cobertura pode restringir a extensão da parte aérea da plântula. Além disso, a remoção da cobertura do solo pode aumentar a variação na temperatura do ar estimulando a germinação e a emergência das plântulas.

Beveridge \& Wilsie (1959), Fehr \& Probst (1971), Burris et al. (1973) verificaram que por afetar o potencial de armazenamento, o desempenho da planta no campo pode ser influenciado pelo tamanho do propágulo. Baker (1972) comparou a biomassa de sementes com a disponibilidade hídrica de cada habitat da Califórnia. Verificou que para espécies herbáceas havia uma correlação negativa e significativa entre biomassa de sementes e disponibilidade hídrica. Segundo Leishman \& Westoby (1994) essa conclusão deve ser considerada com reserva pois há uma tendência de ocorrer dissemínulos de tamanho maior em condições mais secas. Entretanto, Wulff (1986b) relatou que o tamanho maior dos dissemínulos tanto entre como dentro das espécies está mais associado com habitats não perturbados e sem déficite hídrico

Para McWilliams et al. (1968) é dificil separar as condições de armazenamento das sementes daquelas devido a diferenças genéticas inerentes à planta. No caso de Amaranthus retroflexus L., a biomassa de sua semente mostrou ser dependente do genótipo do ecotipo e do ambiente à que a planta-mãe foi sujeita. Em trigo, foi verificado que a capacidade das sementes grandes produzirem plantas maiores é mais pronunciada em condições de baixa disponibilidade hídrica, alta salinidade, semeadura mais profunda ou em solo com baixo suprimento de nitrogênio, aumentando assim a importância das reservas das sementes como fonte de nutrientes para o crescimento inicial da planta (Lowe \& Ries, 1973; Lafond \& Baker, 1986; Mian \& Nafziger, 1994). Leishman \& Westoby (1994) verificaram que sob condições de laboratório, a sobrevivência da plântula em solo seco foi positivamente associada ao tamanho da semente mas o mesmo ocorreu no campo apenas em condições especiais. Costa et al. (1973) entretanto, relataram que em condições de escassez de água no solo, como as sementes grandes requerem mais água, estão sujeitas a maiores perdas na germinação. Esse fato permite sugerir que a deficiência hídrica no solo contribui 
para retardar e diminuir a germinação das sementes grandes de modo mais drástico no plantio a três centímetros de profundidade.

A planta é dependente do seu sistema radicular para sobreviver. Sistema radicular mais longo tem sido associado ao aumento da capacidade competitiva devido ao potencial para aumentar a absorção de água e nutrientes. Propágulos de tamanho maior conferem maior penetração das raízes no solo (Reader, 1973), maior sobrevivência da semente quando enterrada em maior profundidade no perfil do solo; evita a dessecação durante o periodo seco e aumenta a probabilidade de sobrevivência da semente no solo até que condições ambientais favoreçam seu desenvolvimento. A maior quantidade de reserva metabólica também confere maior rapidez no desenvolvimento da planta (Venable, 1992) e maior vantagem competitiva. Entretanto, estudos realizados por Wulff (1986a) e Jurado \& Westoby (1992) mostraram que plântulas originadas de sementes maiores não alocavam mais recursos para o crescimento da raiz mesmo sob condições de déficit hídrico. Porém, se as raízes das plântulas de dissemínulos grandes são maiores que aqueles de tamanho pequeno devido a maior alocação absoluta e, como biomassa maior de raízes está correlacionada com maior profundidade radicular, então as raízes de plântulas originadas de sementes maiores podem alcançar água colocada mais profundamente no perfil do solo que as pequenas (Leishman \& Westoby, 1994).

Black (1957c) verificou que plantas que cresciam em espaçamento favorável ao seu desenvolvimento, o efeito do tamanho da semente se mantinha indefinitivamente se o suprimento de umidade e de nutrientes permanecessem adequados. Por outro lado, em condições de competição por espaço, nos estádios iniciais de crescimento, a planta originada de semente pequena era afetada principalmente, devido ao efeito da luz.

Plantas que apresentam desfolha e ambiente com disponibilidade de recursos escassos também podem afetar o tamanho das sementes em algumas espécies (Maun \& Cavers, 1971; Stephenson, 1980; Willson \& Price, 1980). O tamanho da semente pode, potencialmente, afetar não apenas as plântulas a que darão origem mas também a geração subseqüente.

Em monocotiledôneas, Bredemeier et al. (2001), verificaram que sementes grandes emitem maiores quantidades de afilhos e raízes. Verificaram também que a superioridade inicial das plantas de trigo originadas de sementes grandes não propiciou aumento no rendimento de grãos quando em condições de campo. 
Espécies que produzem rizomas que contém grandes quantidades de reservas nutritivas, quando sob condições favoráveis, podem dar origem a novas plantas se qualquer pedaço do rizoma contiver gemas não sendo observado efeito de tamanho (Turner, 1968). White \& Gonzáles (1990) comparando genótipos de feijoeiro com sementes de tamanhos diferentes, observaram que, embora haja efeito do ambiente, há uma relação negativa entre tamanho de disseminulo e rendimento de grãos. Perin et al. (2002) verificando o efeito do tamanho de sementes de feijoeiro de diferentes genótipos, em condição de campo, verificaram que sementes grandes conferiram maior altura da planta, indice de área foliar, biomassa da parte aérea e de raízes de catorze até 70 dias após a semeadura. Entretanto, não foi observada modificação na biomassa de vagens e efeito na produção de grãos, nos componentes da produção e no índice de colheita. Verificaram também que sementes de tamanho maior podem antecipar o crescimento do feijoeiro mas as plantas oriundas de disseminulos pequenos podem compensar seu menor crescimento garantindo igual produção de grãos. 


\section{EFEITO DA PALHA DE CANA-DE-AÇÚCAR E DO TAMANHO DOS TUBÉRCULOS NA FORMAÇÃo dE BULBOS BASAIS, RIZOMAS E TUBÉRCULOS DE CYPERUS ROTUNDUS L.}

\section{Resumo}

$\mathrm{Na}$ maioria das áreas plantadas com cana-de-açúcar, na colheita, ainda é utilizado o fogo para eliminação dos restos da cultura. Entretanto, desde 2001, legislação estadual paulista estabeleceu normas para que o emprego do fogo na colheita da cana seja gradualmente eliminado e que seja adotada a colheita mecanizada. Essa prática, chamada de cana crua, deixa uma camada espessa de palha sobre o solo, que pode afetar o desenvolvimento das plantas daninhas, especialmente da tiririca que é uma das mais importantes para a cultura da cana-deaçúcar. O objetivo do experimento foi verificar se a adição ao solo de palha de cana-deaçúcar (equivalente a 0,0, 5,0, 10,0 e 15,0 t/ha) poderia afetar o desenvolvimento das estruturas subterrâneas de tiririca provenientes de tubérculos de tamanho pequeno $(0,22$ a $0,34 \mathrm{~g})$ e grande $(1,01$ a $1,14 \mathrm{~g})$, plantados em maio, julho e setembro. Em cada época de instalação do experimento, a cada 28 dias até 84 dias, os rizomas, os tubérculos e os bulbos basais da tiririca foram separados e contados. Tubérculos de tamanho grande originaram maior número de estruturas subterrâneas que os pequenos. Verificou-se que o número de rizomas e de tubérculos + bulbos basais foram maiores no plantio de setembro e menores em julho. A adição de palha de cana-deaçúcar causou redução no desenvolvimento das estruturas subterrâneas seguindo, para todas as variáveis, uma equação de segundo grau, ocorrendo redução máxima com até 10,0 t/ha. Para o efeito de época de avaliação foram observados aumentos lineares em função do tempo para todas as variáveis analisadas. 


\section{EFFECT OF SUGARCANE HARVEST STRAW AND TUBER SIZE ON FORMATION OF THE BASAL BULBS, RHIZOME AND TUBERS OFCYPERUS ROTUNDUS L.}

\section{Summary}

One of the critical aspects in sugar cane production is the interference imposed by the presence of weeds, mainly purple nutsedge (Cyperus rotundus L.). The São Paulo State Legislation established the gradual use of mechanical harvest of sugar cane, which causes accumulation of a thick straw layer that can affect the development of purple nutsedge. This experiments aimed to verify if the addition of sugar cane straw could affect the development of the underground structures of purple nutsedge deriving from small $(0,22-0,34 \mathrm{~g})$ and large $(1,01-1,14 \mathrm{~g})$ tubers, planted during different times of the year. So, dormant purple nutsedge of small and large sizes were planted in May, July and September, and sugar cane straw was added in quantities equivalent to $0,0,5,0 ; 10,0$ and 15,0 ton/ha. During each planting period, at every 28 days until 84 days, purple nutsedge rhizomes, tubers and basal bulbs were separated and counted. Large-sized tubers originated a larger number of underground structures than the small-sized ones. It was verified that the number of rhizome and tubers + basal bulbs were larger when planted in September and smaller in the July planting. The addition of sugar cane straw caused a reduction on the development of underground structures following, for all variables, a second order equation, the maximum reduction occurring with up to 10,0 t/ha. As for the time effect evaluation, linear increases were observed as a function of time for all variables. Tubers planted in September and in May produced, respectively, larger and smaller number of rhizomes and of tubers + basal bulbs.

\subsection{Introdução}

A cultura da cana-de-açúcar emprega alta tecnologia no preparo do solo, plantio e tratos culturais o que reduz os custos e o tempo necessário para a realização dessas operações. Entretanto, para a colheita, a tecnologia vem sendo introduzida aos poucos. Na maioria das áreas com cana-de-açúcar, na colheita, ainda é utilizado fogo para eliminação dos restos da cultura. Essa técnica vêm ocasionado diversos problemas principalmente em lavouras localizadas próximas às áreas urbanas. $\mathrm{O}$ emprego do fogo na colheita, além de poluir o ambiente e contribuir para o efeito 
estufa, libera para a atmosfera gases tóxicos primários como monóxido e dióxido de carbono, metanos e hidrocarbonetos que provocam e agravam doenças respiratórias e cardio-vasculares (Cruz, sd). Além disso, a fumaça formada durante a queimada é responsável por muitos acidentes em rodovias.

Em 2001, no Estado de São Paulo, o decreto no. 45869 de 22 de junho regulamentou a queima da cana-de-açúcar estabelecendo a eliminação gradativa do fogo sendo que este seria totalmente proibido em 2020. Entretanto, o decreto n ${ }^{\circ} .47700$ de 11 de março de 2003, prorrogou para 2021 e 2031, respectivamente, a permissão do uso de fogo para áreas mecanizável e não mecanizável.

A colheita da cana-de-açúcar sem a utilização do fogo, chamada de cana crua, deixa uma espessa camada de palha depositada sobre o solo que ocasiona mudanças nas condições químicas, físicas e biológicas do ambiente agrícola. Essas modificações afetam a brotação e crescimento das plantas e a ação dos herbicidas no controle das plantas daninhas. Para Furlani Neto (1994), a cana crua traz ao ambiente agrícola mais vantagens que a queimada pois proporciona maior proteção ao solo contra a erosão, maior incorporação de matéria orgânica, maior atividade microbiana do solo, redução da poluição ambiental e oferta de matéria-prima de melhor qualidade para a indústria. Além dessas vantagens, Rozeff (1995) relatou que a maior retenção de umidade pela palha, diminuía a necessidade de irrigação em locais com problemas de déficit hídrico e aumentava o teor de açúcar nos colmos pela não ocorrência de perda por exsudação causada pelo fogo.

Por outro lado, Álvarez \& Castro (1999) relatam diversos pontos negativos, como o aumento no ataque de pragas como a cigarrinha de raiz e broca e na incidência de doenças como as podridões, favorecidas pela presença de palha durante a fase inicial de crescimento, irregularidade da brotação da cana devido à presença do palha, queda da produtividade em variedades suscetiveis ao palha, dificil utilização em áreas não mecanizáveis e necessidade obrigatória de colhedora pela dificuldade de se utilizar corte manual em canaviais sem queima.

Com a colheita mecanizada, a palhada deixada sobre o solo forma uma barreira física que pode evitar a infestação por plantas daninhas, pois reduz a incidência da luz (Arévalo, 1998) e modifica o microclima local. Segundo Teasdale (1996), o emprego de cobertura do solo para controlar plantas daninhas tem como objetivo principal a substituição de uma população não manejável por uma cobertura que pode ser manejada. Com isso ocorre ajustamento da fenologia da cultura para preencher o espaço antes ocupado por populações de espécies infestantes. 
A tiririca é uma das principais infestantes dos canaviais (Holm et al., 1977) sendo considerada uma das mais daninhas do mundo por sua ampla distribuição, capacidade de competição, agressividade, assim como pela dificuldade em ser controlada ou erradicada (Bendixen \& Nandihalli, 1987; Stoller \& Sweet, 1987; Kissmann, 1997 e Lorenzi, 2000). Segundo Durigan (1991), o fato de a tiririca permanecer na área do canavial de um ano para outro, a torna mais competitiva. Embora o prejuízo que a tiririca causa no desenvolvimento da planta e, por conseqüência na produção seja decorrente da competição exercida durante todo o ciclo, ela é mais daninha na fase inicial do desenvolvimento das culturas (Kissmann, 1997). Kuva et al. (2000) observaram que a cana suporta um curto período de convivência inicial com as plantas daninhas sem sofrer interferência na produção. Entretanto, quanto à tiririca, para assegurar a produção econômica, é necessário que seja feito controle até 22 dias após o plantio da cana.

Em uma comunidade vegetal, o principal meio utilizado pela tiririca para colonizar a área, é através da emissão de rizomas que podem crescer em qualquer direção no solo (Urbatsch \& Skinner, 2000). Quando seu crescimento é ascendente, alcançando a superficie do solo e com a incidência da luz, ocorre um engrossamento do rizoma e origina o bulbo basal que produz brotações, raízes e outros rizomas. Se o crescimento é descendente e horizontal forma tubérculos individuais ou cadeia de tubérculos (The Ojos Negros Research Group, sd). Os tubérculos e os bulbos basais servem como propágulos vegetativos.

A redução na produção é devida ao fato da tiririca desenvolver várias brotações que são conectadas a uma rede subterrânea de bulbos, rizomas e tubérculos (Wills, 1975) o que reduz o desenvolvimento do sistema radicular da cultura. Nos tubérculos, há uma grande reserva de carboidratos que está disponivel em cada estação de crescimento, por isso, a tiririca compete com vantagem com as culturas (Matthiesen \& Stoler, 1978; Radosevich \& Holt, 1984 e Holt \& Orcutt, 1991).

O tamanho das sementes ou dos dissemínulos é um fator reconhecido que afeta o vigor das plântulas e, subseqüentemente, o crescimento da planta e a sua produção (Smith \& Camper Junior, 1975). Há artigos científicos discutindo o efeito do tamanho da sementes ou dos dissemínulos na produção de plantas cultivadas, principalmente em graniferas (Black, 1957a, b e c e Burris et al., 1973), mas para a tiririca são poucos. Hammerton (1975c) verificou que tubérculos de tamanho grande têm maior número de gemas e mais biomassa que os pequenos, podendo emitir brotações e se estabelecer mais rapidamente. 
O objetivo do experimento foi verificar se a adição de quantidades diferentes de palha de cana-de-açúcar ao solo poderia afetar a formação das estruturas subterrâneas de tiririca provenientes de tubérculos de tamanho pequeno e grande, plantados em diferentes épocas do ano.

\section{2 Material e Métodos}

O experimento foi instalado na casa-de-vegetação do Centro de Ecofisiologia e Biofísica, do Instituto Agronômico, em Campinas, SP, em 27/05, 03/07 e 08/09/2003 e disposto em blocos ao acaso, com quatro repetições. Os tratamentos consistiam na combinação fatorial entre o tamanho de tubérculo de tiririca, pequeno e grande, e quantidades de palhas equivalentes a $0,0,5,0,10,0$ e 15,0 t/ha, que foram adicionadas à superficie do solo. A palha de cana-de-açúcar era do cultivar RB 855156 e foi coletada na Usina Costa Pinto, em Piracicaba, SP.

Nos meses de maio, julho e setembro de 2003 no Centro Experimental do Instituto Agronômico em Campinas, SP, foram coletadas plantas inteiras de tiririca. Dessas plantas foram retirados tubérculos dormentes, com aspecto sadio e que não apresentassem danos físicos. Os tubérculos foram limpos com papel toalha, separados quanto ao tamanho, em grandes e pequenos, acondicionados em latas de alumínio e mantidos sob refrigeração por, no máximo, três dias até o plantio. Logo após a separação dos tubérculos foram avaliadas as biomassas frescas média dos tubérculos denominados de pequeno e grande (Tabela 1). Para tanto foram coletadas, ao acaso, dez subamostras com dez indivíduos cada e avaliou-se as biomassas fresca para cada tamanho.

Tabela 1. Biomassa fresca de tubérculos dormentes de tiririca classificados como grande e pequeno nas diferentes épocas de instalação do experimento

\begin{tabular}{lccc}
\hline Tamanho dos tubérculos & \multicolumn{3}{c}{ Datas dos plantios dos tubérculos } \\
& $27 / 05 / 2003$ & $03 / 07 / 2003$ & $08 / 09 / 2003$ \\
\hline Pequeno & $0,22 \mathrm{~g}$ & $0,31 \mathrm{~g}$ & $0,34 \mathrm{~g}$ \\
Grande & $1,01 \mathrm{~g}$ & $1,07 \mathrm{~g}$ & $1,14 \mathrm{~g}$ \\
\hline
\end{tabular}

Da mesma área de onde foram retiradas as plantas de tiririca, foi coletado solo na profundidade de 0,0 a $0,20 \mathrm{~m}$ que foi peneirado sob crivo fino para retirada de torrões, restos de vegetais e de tubérculos de tiririca e colocado em vasos plásticos de 
seis litros, com furos para percolação da solução do solo. As características de fertilidade e de granulometria do solo nas coletas realizadas em maio, julho e setembro são apresentadas na Tabela 2.

Tabela 2. Resultados das análises de fertilidade do solo e de granulometria de amostras coletadas na camada 0 a $0,20 \mathrm{~m}$, nas diferentes épocas de instalação do experimento, em Campinas, SP, 2003

\begin{tabular}{|c|c|c|c|c|c|c|c|c|c|c|}
\hline Época & & & & Mac & onutrie & ntes & & & & \\
\hline $\begin{array}{c}\text { de } \\
\text { plantio }\end{array}$ & 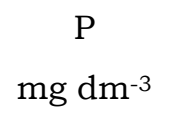 & $\begin{array}{l}\text { M.O. } \\
\text { g/dm³ }\end{array}$ & $\mathrm{pH}_{\mathrm{CaCl} 2}$ & K & $\mathrm{Ca}$ & $\begin{array}{l}\mathrm{Mg} \\
\mathrm{mm}\end{array}$ & $\begin{array}{c}\mathrm{H}+\mathrm{Al} \\
\mathrm{ol}_{\mathrm{c}} / \mathrm{dm}^{3}\end{array}$ & $\mathrm{SB}$ & CTC & $\begin{array}{l}\mathrm{V} \\
\%\end{array}$ \\
\hline $27 / 05$ & 56 & 31 & 5,7 & 4,5 & 35 & 14 & 20 & 53,5 & 73,7 & 73 \\
\hline 03/07 & 50 & 22 & 4,9 & 1,3 & 21 & 7 & 31 & 29,3 & 60,1 & 49 \\
\hline 08/09 & 105 & 26 & 5,7 & 3,3 & 43 & 16 & 28 & 62,3 & 90,1 & 69 \\
\hline Época & & Micr & onutrient & & & & & anulom & etria & \\
\hline de & B & $\mathrm{Cu}$ & $\mathrm{Fe}$ & $\mathrm{Mn}$ & $\mathrm{Zn}$ & & areia total & silte & & argila \\
\hline plantio & & & $\mathrm{ng} / \mathrm{dm}^{3}$ & & & & & $\mathrm{~g} / \mathrm{kg}^{1}$ & & \\
\hline $27 / 05$ & 0,39 & 5,8 & 8 & 29,3 & 2,5 & & 325 & 87 & & 588 \\
\hline 03/07 & 0,16 & 4,6 & 10 & 17,3 & 0,9 & & 338 & 99 & & 563 \\
\hline 08/09 & 0,51 & 5,6 & 8 & 28,3 & 2,5 & & 245 & 230 & & 525 \\
\hline
\end{tabular}

Para cada tratamento foram plantados nas datas acima descritas, seis tubérculos de tiririca na profundidade de 0,03 m. Em intervalos regulares, de 28 dias até 84 dias, para cada época de instalação foram realizadas avaliações do desenvolvimento do sistema subterrâneo. A parte aérea foi cortada, descartada e lavouse o sistema subterrâneo com água sob pressão para a retirada da terra. Após a lavagem, o sistema subterrâneo foi seco em papel absorvente, separado nas diferentes estruturas (rizomas, tubérculos e bulbos basais) e contadas.

Os dados de número de tubérculos + bulbos basais e de rizomas foram transformados em raiz de $\mathrm{x}+1$, submetidos à análise de variância usando o teste $\mathrm{F}$ e, quando significativo, o efeito dos tamanhos dos dissemínulos teve suas médias comparadas pelo teste de Tukey. Para o efeito de época de avaliação, de instalação e de dose de palhada foi usado ajuste empregando-se funções matemáticas. 


\subsection{Resultados e Discussão}

Para a tiririca, verificou-se que plantas originadas de tubérculos grandes produziram maior número de rizomas e de tubérculos + bulbos basais que as provenientes de dissemínulos pequenos (Tabela 3). Não houve diferença significativa quanto ao número de estruturas subterrâneas formadas para as interações entre tamanho e época de plantio de dissemínulos e tamanho de tubérculos e época de avaliação (dados não apresentados). Segundo Hammerton (1975c), o tamanho do tubérculo da tiririca reflete o tempo disponível para seu desenvolvimento. O início do florescimento também pode ser um fator para que a biomassa seca do tubérculo seja mais baixa sugerindo que ocorre competição por fotossintetizados entre as estruturas. Hammerton (1975c) verificou também que quinze dias após o plantio dos tubérculos, já se observava efeito do tamanho do tubérculo. Nessa ocasião já se observavam novos tubérculos.

Tabela 3. Efeito do tamanho dos tubérculos de tiririca no número de rizomas e de tubérculos + bulbos basais formados Campinas, SP, 2003

\begin{tabular}{lcc}
\hline Tamanho dos tubérculos & Rizomas & \multicolumn{2}{c}{ Tubérculos + bulbos basais } \\
& \multicolumn{1}{c}{$\mathrm{n}^{0.1}$} \\
\hline Pequeno & $20,95 \mathrm{a}$ & $22,90 \mathrm{~b}$ \\
Grande & $24,71 \mathrm{a}$ \\
\hline 1. Os dados foram transformados em raiz de $\mathrm{x}+1$ para análise estatística. \\
2. Médias seguidas por letras iguais na coluna, que comparam o tamanho dos tubérculos, não \\
\multicolumn{2}{l}{ diferem entre si pelo teste de Tukey a 5\%. }
\end{tabular}

Rowsell et al. (2003) avaliando o efeito do tamanho de sementes de trigo na produção de grãos, verificaram que plantas originadas de dissemínulos grandes, apresentaram produções maiores que os provenientes de estruturas pequenas. Entretanto, o número de indivíduos da população resultante não era afetado. Isso ocorre porque dissemínulos de tamanho grande, por possuírem reservas metabólicas maiores, apresentam vantagem competitiva. Conferem às raízes maior habilidade na penetração do solo (Reader, 1993), favorecem o crescimento inicial das plântulas, principalmente, em solos pobres em nutrientes e, aumentam a possibilidade de sobrevivência da planta quando o ambiente é pouco favorável como, por exemplo, em condições de baixa disponibilidade hídrica (Bredemeier et al., 2001). Além disso, segundo Popinigis (1977), para muitas espécies, o tamanho do dissemínulo, 
principalmente de sementes, é indicativo de melhor qualidade fisiológica. Entretanto, essa tendência apresenta exceções pois, para muitas espécies, a vantagem inicial de possuir maior reserva metabólica, é afetada pela época de emergência, pela forma e pela taxa de crescimento da planta e também pelo tipo de cobertura do solo (Gelmond, 1978 e Gross, 1984). Stoller et al. (1972) não encontraram diferença na porcentagem de germinação de tubérculos de C. esculentus provenientes de lotes de diversos tamanhos, porém observaram que havia influência no vigor das plântulas produzidas.

A formação dos rizomas foi afetada pela adição de palha ao solo, sendo observado maior número nas plantas originadas de tubérculos grandes e com 0,0, 10,0 e 15,0 t/ha de palha (Tabela 4). Com a adição de 5,0 t/ha de palha, não houve diferença no número de rizomas provenientes de tubérculos grandes e pequenos. Em plantas originadas de tubérculos grandes, houve redução linear no número de rizomas formados com o aumento da quantidade de palha adicionada; entretanto, para dissemínulos pequenos houve redução até a adição de 7,9 t/ha (Tabela 4). Não houve interação significativa entre tamanho de tubérculos e quantidade de palha para número de tubérculos + bulbos basais (dados não apresentados).

Tabela 4. Efeito da interação entre o tamanho dos tubérculos de tiririca e a quantidade de palha adicionada ao solo na formação de rizomas

\begin{tabular}{|c|c|c|c|c|c|}
\hline \multirow{3}{*}{$\begin{array}{l}\text { Tamanho } \\
\text { do } \\
\text { Tubérculo }\end{array}$} & \multicolumn{5}{|c|}{ Número de rizomas ${ }^{1}$} \\
\hline & \multicolumn{4}{|c|}{ Quantidade de Palha } & \multirow{2}{*}{$\begin{array}{c}\text { Equações de ajuste e } \\
\text { coeficiente de determinação² }\end{array}$} \\
\hline & $0,0 \mathrm{t} / \mathrm{ha}$ & $5,0 \mathrm{t} / \mathrm{ha}$ & $10,0 \mathrm{t} / \mathrm{ha}$ & $15,0 t / h a$ & \\
\hline Pequeno & $19,10 b^{3}$ & $17,54 a$ & $16,61 b$ & $18,86 \mathrm{~b}$ & $\mathrm{Y}=4,50-0,070 \mathrm{x}+0$ \\
\hline Grande & $24,97 a$ & $18,98 \mathrm{a}$ & $18,82 \mathrm{a}$ & $21,31 \mathrm{a}$ & $Y=4,86-0,023 x$ \\
\hline
\end{tabular}

1 Os dados foram transformados em raiz de $\mathrm{x}+1$ para análise estatística.

2 Equações de regressão e coeficientes de determinação para o efeito da quantidade de palha adicionada ao solo dentro de cada tamanho de tubérculo.

3 Médias seguidas pela mesma letra, na coluna, que comparam o efeito do tamanho do tubérculo para cada quantidade de palha adicionada ao solo, não diferem entre si pelo teste de Tukey a $5 \%$

A adição de palha de cana-de-açúcar no solo ocasionou redução no número de rizomas e de tubérculos + bulbos basais sendo observado que os menores valores foram obtidos com quantidade de palha equivalentes a 8,3 e 9,0 t/ha, respectivamente (Figuras 1A e 1B). Velini \& Negrisoli (2000) destacam o efeito da palha de cana-deaçúcar na incidência da luz no solo. Com adição de palha, a quantidade e a qualidade da luz incidente sobre o solo é modificada podendo afetar a germinação das sementes e 
dos propágulos de plantas daninhas. Segundo Teasdale (1996), a interceptação e a reflexão da radiação de onda curta pela cobertura morta reduz a quantidade de luz disponivel que ativa o fitocromo mediador da germinação; reduz também a absorção de calor pelo solo durante o dia e a perda de água do solo por evaporação.
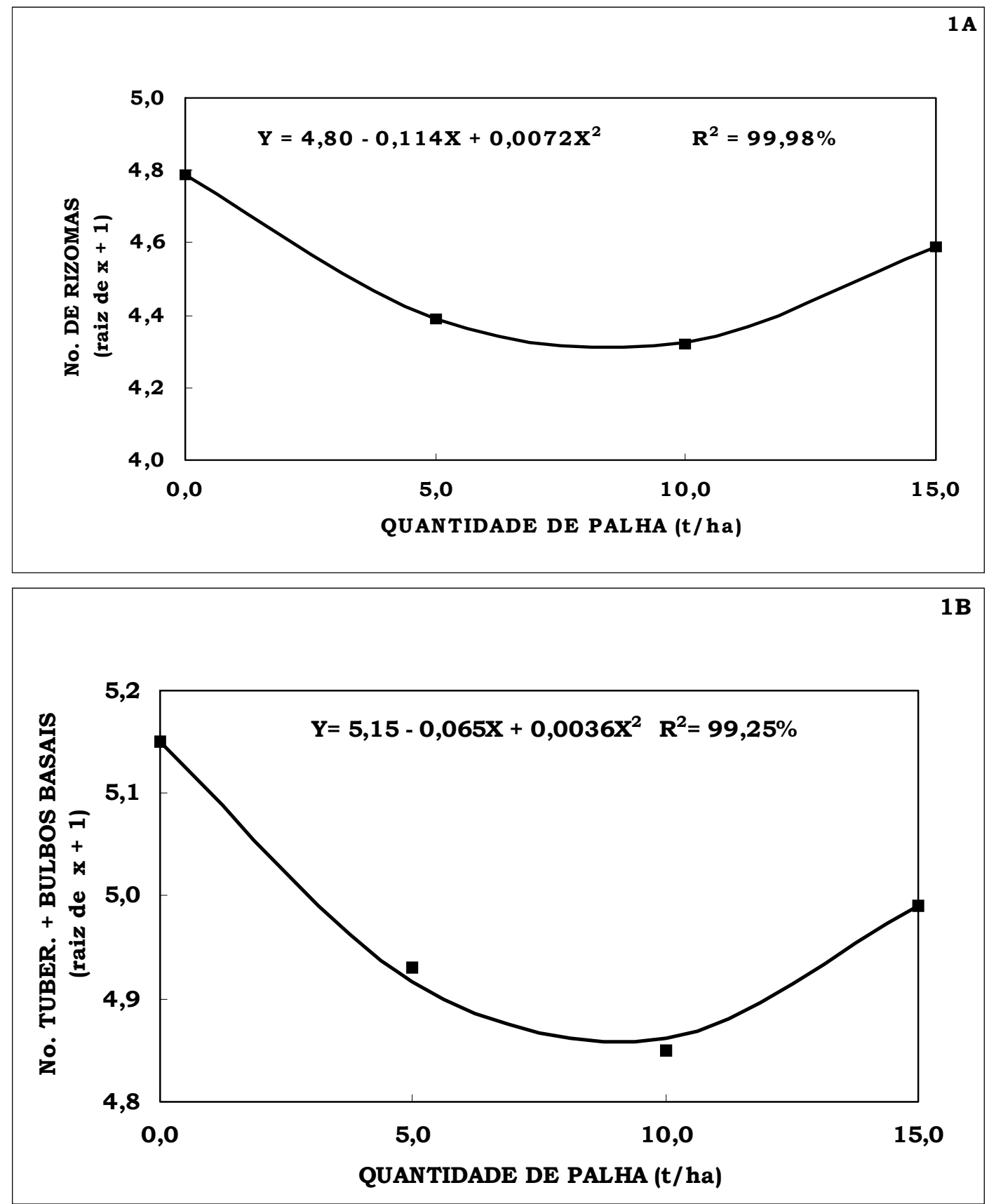

Figura 1 - Efeito da quantidade de palha adicionada ao solo na formação de rizomas (1A) e tubérculos + bulbos basais (1B) 
Em relação à época de plantio dos tubérculos, verificou-se que, para quaisquer das quantidades de palha adicionadas, em setembro e julho foram observados, respectivamente, maiores e menores números de rizomas e de tubérculos + bulbos basais (Tabela 5). No plantio de tubérculos realizado em maio, foi verificada redução no número de rizomas e de tubérculos + bulbos basais até a quantidade aproximada de 7,0 t/ha. No plantio de julho, verificou-se que a adição de palha favoreceu a formação de estruturas subterrâneas sendo observado aumento linear no número de rizomas e de tubérculos + bulbos basais. Em setembro, a adição de palha reduziu linearmente a formação de rizomas e o número de tubérculos + bulbos basais, atingindo o valor minimo quando foram colocadas $13,9 \mathrm{t}$ / ha (Tabela 5).

A diferença observada na formação de rizomas e de tubérculos + bulbos basais nos plantios realizados em julho e setembro, segundo Miles et al. (1996), pode ser causada pela diferença da temperatura ambiente quando da coleta dos tubérculos no campo. Coletas de tubérculos sob temperaturas mais altas resultam em maior número de brotações e de desenvolvimento da planta. O favorecimento na formação de estruturas subterrâneas com a adição de palha no plantio de julho, se deve à manutenção da temperatura mínima exigida para a germinação dos tubérculos.

Estudos realizados por Shamsi et al. (1978) mostraram que a temperatura ótima para a brotação da tiririca é de 25 a $35^{\circ} \mathrm{C}$, sendo a mínima e a máxima, respectivamente, de 10 e $40^{\circ} \mathrm{C}$ (Miles et al., 1996). A adição de palha de cana-deaçúcar, dependendo da quantidade, afeta a amplitude térmica da camada de solo onde ficam situados a maioria dos tubérculos de tiririca podendo reduzir sua brotação. Miles et al. (1996 e 2002) observaram que em condições térmicas adversas, os tubérculos de tiririca permanecem dormentes e constituem uma reserva de material propagativo no solo.

Geralmente, o aquecimento do solo acompanhado de regime de chuvas mais freqüente estimula a brotação da tiririca. A redução do número de rizomas e de tubérculos + bulbos basais observada nos plantios de maio e setembro, deve ter sido causada pelo aumento no sombreamento causado pela palha já que nessas épocas não ocorreu estresse térmico. Segundo Wills (1975), Jordan-Molero et al. (1978) e Patterson (1982), o sombreamento reduz o número e o tamanho dos tubérculos produzidos.

Hammerton (1975c) verificou também que o fotoperíodo influenciava ainda o crescimento e o desenvolvimento da tiririca mas essa relação pode ser confundida com a biomassa seca do tubérculo de origem. Verificou também, como observado neste experimento, que sob dias mais curtos, a produção de tubérculos começa mais tarde, 
sendo formados menor número de tubérculos em função da menor quantidade de radiação solar recebida.


Figura 2 - Efeito da interação entre quantidade de palha de cana-de-açúcar adicionada ao solo (2A) e época de amostragem quanto ao número de rizomas (2B)

Não houve interação entre quantidade de palha adicionada e época de avaliação para número de tubérculos + bulbos basais. A adição de palha reduziu o número de 
rizomas formados nas amostragens realizadas aos 56 e 84 dias após o plantio (Figura 2A) atingindo nestas amostragens valores mínimos com 8,0 t/ha. Aos 28 dias, a adição de palha não afetou a formação de rizomas. O efeito de época de avaliação dentro de cada quantidade de palha adicionada na formação de rizoma é apresentado na Figura 2B. Verificou-se que para quaisquer das quantidades de palha adicionada foi observado aumento linear no número de rizomas em função do tempo.

De maneira geral, foi observado que nas avaliações realizadas aos 28,56 e 84 dias, o número de rizomas e de tubérculos + bulbos basais foi maior no plantio de setembro e menor em julho (Tabela 6). Para quaisquer das épocas de plantio dos dissemínulos, foi verificado que o número de rizomas e de tubérculos + bulbos basais aumentou linearmente com o tempo.

Tabela 6. Efeito da interação entre época de plantio dos tubérculos e época de avaliação na formação de rizomas e de tubérculos + bulbos basais da tiririca

\begin{tabular}{|c|c|c|c|c|c|}
\hline Época de plantio & \multicolumn{3}{|c|}{ Número de rizomas $^{1}$} & \multirow{2}{*}{\multicolumn{2}{|c|}{$\begin{array}{c}\text { Equações de ajuste e } \\
\text { coeficiente de determinação² }\end{array}$}} \\
\hline dos tubérculos & 28 dias & 56 dias & 84 dias & & \\
\hline Maio & $7,00 \mathrm{~b}^{3}$ & $22,37 \mathrm{~b}$ & $41,13 \mathrm{~b}$ & $Y=1,06+0,065 x$ & $\mathrm{R}^{2}=99,70 \%$ \\
\hline Julho & $1,29 \mathrm{c}$ & $12,45 \mathrm{c}$ & $17,76 \mathrm{c}$ & $Y=0,35+0,050 x$ & $\mathrm{R}^{2}=91,46 \%$ \\
\hline Setembro & $9,85 \mathrm{a}$ & $31,68 \mathrm{a}$ & $63,54 \mathrm{a}$ & $Y=0,94+0,084 x$ & $\mathrm{R}^{2}=99,98 \%$ \\
\hline Época de plantio & \multicolumn{3}{|c|}{$\mathrm{N}^{\circ}$. tubérculos+bulbos basais ${ }^{1}$} & \multirow{2}{*}{\multicolumn{2}{|c|}{$\begin{array}{c}\text { Equações de ajuste e } \\
\text { coeficiente de determinação }\end{array}$}} \\
\hline dos tubérculos & 28 dias & 56 dias & 84 dias & & \\
\hline Maio & $6,38 b^{3}$ & $29,62 \mathrm{~b}$ & $47,72 \mathrm{~b}$ & $Y=0,81+0,076 x$ & $R^{2}=96,67 \%$ \\
\hline Julho & $5,46 \mathrm{~b}$ & $15,96 \mathrm{c}$ & $21,56 \mathrm{c}$ & $\mathrm{Y}=1,62+0,0391 \mathrm{x}$ & $\mathrm{R}^{2}=94,36 \%$ \\
\hline Setembro & $11,54 \mathrm{a}$ & $41,06 \mathrm{a}$ & $65,08 \mathrm{a}$ & $Y=1,46+0,082 x$ & $\mathrm{R}^{2}=97,40 \%$ \\
\hline
\end{tabular}

\subsection{Conclusões}

Concluiu-se que:

1) Tubérculos de tamanho grande produziram maior número de rizomas e de tubérculos + bulbos basais que os pequenos.

2) O número de rizomas e de tubérculos + bulbos basais foram maiores no plantio de 
setembro e menores em julho.

3) A adição de palha de cana-de-açúcar causou redução no desenvolvimento de rizoma e de tubérculos + bulbos basais.

4) Foram observados aumentos lineares em função do tempo para todas as variáveis analisadas. 


\section{EFEITO DA PALHA DE CANA-DE-AÇÚCAR E DO TAMANHO DOS TUBÉRCULOS NA BIOMASSA DAS ESTRUTURAS SUBTERRÂNEAS DE CYPERUS ROTUNDUS L.}

\section{Resumo}

A legislação estadual paulista estabeleceu normas para a eliminação gradativa do uso do fogo e o emprego de colheita mecanizada da cana-de-açúcar. A colheita mecanizada deixa uma camada espessa de palha que afeta o desenvolvimento das

plantas daninhas. Uma das principais plantas daninhas em cana-de-açúcar é a tiririca, Cyperus rotundus L. cujo desenvolvimento pode ser afetado pela palhada de cana-de-açúcar. O objetivo do experimento foi verificar se a adição de palha de canade-açúcar RB 855156 nas quantidades correspondente a 0,0, 5,0, 10,0 e 15,0 t/ha poderia afetar a biomassa das estruturas subterrâneas de plantas de tiririca provenientes de tubérculos de tamanho pequeno $(0,22$ a $0,34 \mathrm{~g})$ e grande $(1,01$ a $1,14 \mathrm{~g})$, plantados em maio, julho e setembro. Para cada época de instalação do experimento, a cada 28 dias até 84 dias, as partes subterrâneas da tiririca foram separadas nas diferentes estruturas e determinou-se suas biomassas fresca e seca. De modo geral, o tamanho maior dos tubérculos favoreceu o desenvolvimento da parte subterrânea sendo que plantas originadas de tubérculos de tamanho grande apresentaram maiores biomassas. A adição de palha de cana-de-açúcar causou redução no desenvolvimento das diferentes estruturas subterrâneas seguindo uma equação de segundo grau. Verificou-se que as biomassas foram maiores no plantio de setembro, exceto para biomassa fresca de tubérculos, que foi maior em maio. Para o efeito de época de amostragem foram observados aumentos lineares em função do tempo para todas as variáveis analisadas. 


\section{EFFECT OF SUGARCANE HARVEST STRAW AND TUBER SIZE ON THE UNDERGROUND SYSTEM WEIGHT OF CYPERUS ROTUNDUS L.}

\section{Summary}

The São Paulo State's Legislation established the gradual elimination of the use of fire and the employment of a mechanical harvest for the sugar cane, which forms a thick straw layer that can affect the growth of weeds. One of the main weeds on sugar cane is the purple nutsedge, Cyperus rotundus L. The sugar cane straw layer left over the soil can affect the development of the purple nutsedge. The purpose of the experiment was to verify if the addition of different quantities of sugar cane straw would affect the biomass of the underground structures of purple nutsedge deriving from small $(0,22$ to $0,34 \mathrm{~g})$ and large $(1,01$ to $1,14 \mathrm{~g})$ sized tubers, planted at different times of the year. Dormant purple nutsedge tubers of small and large size were planted in plastic pots with clay soil in May, July and September, and RB 855156 sugar cane straw was added in quantities corresponding to $0,0,5,0,10,0$ and 15,0 t/ha. For each planting period, every 28 days up to 84 days, the underground parts of the purple nutsedge were separated into its different structures and their fresh and dry biomass were determined. In general, the larger size of the tubers favored the development of the underground parts. It was noted that the plants originated from large sized tubers presented greater fresh and dry biomass. The adding of increasing quantities of sugar cane straw caused reduction in the growth of the different underground structures following, a second degree equation. Greater fresh and dry biomasses were observed on the September planting, except for the tubers fresh biomass, which were greater in May. The effects of the sampling period showed linear growths in function of time for all variables were observed.

\subsection{Introdução}

A tiririca é uma das principais infestantes dos canaviais sendo considerada uma das mais prejudicais às culturas de todo o mundo (Holm et al., 1977) por sua ampla distribuição, capacidade de competição, agressividade e pela dificuldade em ser controlada ou erradicada (Stoller \& Sweet, 1987). A espécie produz poucas sementes viáveis (Justice \& Whitehead, 1946) sendo seu principal método de propagação, o vegetativo por meio de bulbos basais e tubérculos (Miles et al., 2002). Seus tubérculos 
podem sobreviver por mais de três anos ficando dormentes no solo (Neeser et al., 1997). Uma pequena porcentagem de tubérculos que sobreviva pode rapidamente se multiplicar e tornar um sério problema às culturas (Hauser, 1962 a).

No Estado de São Paulo devido, principalmente a problemas sanitários e ambientais, foram estabelecidas, por legislação, normas para a colheita da cana-deaçúcar. A queima da cana-de-açúcar deverá ser eliminada gradualmente e será substituída por colheita mecanizada. Essa deixa uma camada espessa de palha sobre o solo afetando as condições químicas, físicas e biológicas do ambiente agrícola. As modificações do ambiente físico e químico do ambiente afetam a brotação e o crescimento das plantas daninhas e a ação dos herbicidas no controle destas (Azania et al., 2002). No caso da tiririca há relatos que, em condições de colheita mecanizada, ocorre redução temporária no número de brotações, mas este não é acompanhado de diminuição na biomassa subterrânea (Silva et al., 2003).

Há poucos relatos sobre o efeito do tamanho de dissemínulos de tiririca em sua brotação e desenvolvimento (Hammerton 1975 a, b e c). Entretanto, quanto ao efeito do tamanho de semente para as culturas de soja, trigo e trevo há diversos relatos como por exemplo os trabalhos de Andersen (1970), Lafond \& Baker (1986) e Black (1957). $\mathrm{Na}$ maioria dos trabalhos, as plantas oriundas de sementes de tamanho grande apresentaram maior crescimento e desenvolvimento mas em todos há restrição à generalização devido ao efeito do ambiente e das condições de solo (Gelmond, 1978)

O objetivos do trabalho foi verificar se a adição de diferentes quantidades de palha de cana-de-açúcar poderia afetar a biomassa das estruturas subterrâneas de plantas de tiririca provenientes de tubérculos de tamanho pequeno e grande, plantados em diferentes épocas do ano.

\section{2 Material e Métodos}

Nos meses de maio, julho e setembro de 2003 na Estação Experimental do Instituto Agronômico em Campinas, SP, foram coletadas plantas de tiririca. Foram descartadas suas partes aéreas, rizomas e raízes e retirados tubérculos dormentes, túrgidos, com aspecto sadio e que não apresentassem danos físicos. Os tubérculos foram limpos com papel toalha, separados quanto ao tamanho, grande e pequeno, acondicionados em latas de alumínio e mantidos sob refrigeração por, no máximo três dias, até o plantio. Logo após a separação dos tubérculos foram coletadas, para cada tamanho de tubérculos, ao acaso, dez amostras com dez indivíduos cada e avaliou-se 
suas biomassas fresca (Tabela 1, página 33).

Da mesma área de onde foram retiradas as plantas de tiririca, foi coletado solo na profundidade de 0 a $0,20 \mathrm{~m}$. Esse foi peneirado sob crivo fino para retirada de torrões, restos de vegetais e de tubérculos de tiririca e colocado em vasos plásticos com capacidade para seis litros, com furos para percolação da solução do solo. Não foi utilizado corretivo ou fertilizante. As características químicas e fisicas do solo das coletas realizadas em maio, julho e setembro são apresentadas na Tabela 2 (página 34).

O experimento foi instalado na casa-de-vegetação do Centro de Ecofisiologia e Biofísica, em Campinas, SP, em 27/05, 03/07 e 08/09/2003 e disposto em blocos ao acaso, com quatro repetições. Os tratamentos consistiam na combinação fatorial entre o tamanho de tubérculo de tiririca, pequeno e grande, e quantidades de palhas que foram adicionadas à superficie do solo.

Para cada tratamento foram plantados, em cada vaso, nas datas acima descritas, seis tubérculos de tiririca na profundidade de 0,03 m. Após o plantio dos tubérculos, o solo foi coberto com quantidades de palha equivalentes a 0,0, 5,0 10,0 e 15,0 t/ha, e todos os vasos foram irrigados até a percolação. A palha de cana-deaçúcar era do cultivar RB 855156 e foi coletada na Usina Costa Pinto, em Piracicaba, SP.

Em intervalos regulares, de 28 dias até 84 dias, para cada época de instalação, foram realizadas avaliações do desenvolvimento do sistema subterrâneo. Em cada época de avaliação, a parte aérea foi cortada e retirou-se a terra com água, sob pressão, para se obter apenas o sistema subterrâneo. Após a lavagem, esse foi seco em papel absorvente, separado nas diferentes estruturas (raiz, rizoma, bulbos basais e tubérculos maduros e imaturos). Para separar tubérculos quanto à sua maturidade foi usado o conceito de Jordan-Molero \& Stoller (1978) que consideram os tubérculos imaturos quando são de cor branca e maduros quando de cor preta ou marron-escuro. Determinou-se a biomassa fresca e seca das diferentes estruturas. Para determinar a biomassa seca, as estruturas foram secas em estufa sob ventilação forçada a $65-70^{\circ} \mathrm{C}$ até atingir massa constante.

Para a análise estatística, além dos parâmetros acima descritos foram também analisados as biomassas fresca e seca do número final de tubérculos (maduros + imaturos) e da parte subterrânea total (raiz + rizomas + tubérculos maduros + tubérculo imaturos). Os dados foram submetidos à análise de variância usando o teste F e, quando significativo, o efeito dos tamanhos dos dissemínulos teve suas médias 
comparadas pelo teste de Tukey. Para o efeito de época de avaliação e de instalação, e de dose de palhada foi usado ajuste empregando-se funções matemáticas.

\subsection{Resultados e Discussão}

Não foi observada diferença estatística quanto à biomassa fresca e seca de tubérculos maduros e imaturos (dados não apresentados). Todas as estruturas subterrâneas da tiririca, provenientes de tubérculos de tamanho grande, apresentaram biomassas fresca e seca maiores que as de dissemínulos pequenos (Tabelas 7, 8 e 9, médias). Há diversos relatos indicando efeitos que dependem do tamanho da semente: afeta a emergência das plântulas (Lafond \& Baker, 1986), o desenvolvimento (Bremner et al., 1963, Evans \& Bhatt, 1977), o tamanho final da planta e a produção (Liu \& Owen, 2003) sendo a maioria em gramíneas e leguminosas. Weis et al. (1982) observaram acréscimo na taxa de germinação e na biomassa de Mirabilis hirsuta com o aumento da biomassa da semente. Observaram também que havia relação direta entre o tamanho da semente, a taxa de crescimento e a biomassa da planta em função da maior quantidade de reservas existente nos dissemínulos. A maior quantidade de reserva nutritiva favorecia a planta no início de seu desenvolvimento, quando ainda seu sistema fotossintético era incipiente. Entretanto para muitas espécies, a vantagem inicial de possuir maior reserva metabólica, é afetada pela época de emergência, pela forma e pela taxa de crescimento da planta e também pelo tipo de cobertura do solo (Gelmond, 1978 e Gross, 1984).

Tabela 7. Efeito do tamanho dos dissemínulos de tiririca na biomassa fresca (BF) de rizomas, e da interação entre tamanho dos tubérculos e época de plantio na biomassa fresca de total de tubérculos (BF) e seca (BS) de rizomas, Campinas, SP, 2003

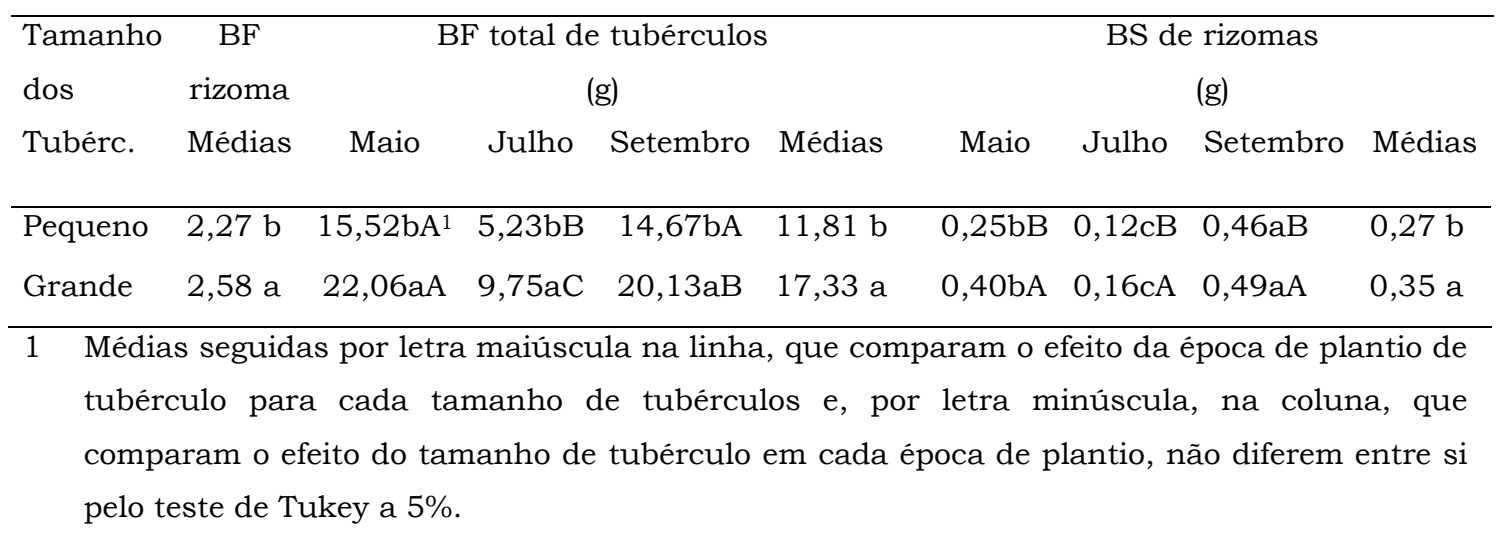


Foi observada interação significativa entre época de plantio e tamanho de disseminulos apenas para biomassa fresca do total de tubérculos e biomassa seca de rizomas (Tabela 7). Em quaisquer das épocas de plantio, as plantas provenientes de tubérculos grandes produziram maiores biomassas. A biomassa fresca do total de tubérculos de plantas provenientes tanto de tubérculos pequenos como grandes foi menor no plantio de julho, não havendo, para tubérculos pequenos, diferença quando a instalação foi feita em maio ou em setembro. Entretanto, para dissemínulos grandes, a biomassa fresca do total de tubérculos foi maior em maio que em setembro (Tabela 7). Segundo Jordan-Molero \& Stoller (1978) nos meses mais frios, como observado na instalação do mês de julho, ocorre diminuição no desenvolvimento da tiririca devido à redução na intensidade de luz entretanto, deve-se considerar também o efeito térmico pois a tiririca é bastante sensivel à baixa temperatura (Wills, 1975). Martins et al. (1999) relataram também que em condições onde há maiores oscilações de temperatura, luz e umidade, como o observado nas instalações de maio e setembro, ocorre menor dormência de sementes de plantas daninhas e portanto, maior brotação e desenvolvimento. Para biomassa seca de rizomas, para qualquer tamanho de dissemínulos, maiores valores foram observados no plantio de setembro e menores em julho (Tabela 7).

Hammerton (1975c) verificou que, para as condições da Jamaica, o crescimento dos rizomas iniciava-se e era mais rápido quando o comprimento do dia aumentava resultando também em aumento no número de tubérculos e de brotação. Sob condições de dia curto, quando o crescimento dos rizomas, a produção de tubérculos e o processo fotossintético eram menores, o florescimento era retardado até que um número mínimo de tubérculos fosse formado. Como o florescimento e a produção de sementes não são meios importantes para a propagação da tiririca, um mecanismo pelo qual a formação de tubérculos tem prioridade sobre a produção de inflorescência, quando as fontes fotossintéticas são relativamente escassas, é uma adaptação valiosa.

Os resultados do efeito da interação entre tamanho de tubérculos e quantidade de palha quanto às biomassas fresca e seca das diferentes estruturas subterrâneas são apresentadas, respectivamente, nas tabelas 8 e 9. Exceto para raiz, as biomassas fresca e seca, com quaisquer das quantidades de palha, foram maiores quando as plantas eram provenientes de dissemínulos grandes. O mesmo foi observado para biomassa fresca e seca de raiz com 0,0, e com a adição de 10,0 e 15,0 t/ ha de palha à superficie do solo (Tabelas 8 e 9). Com a adição de 5,0 t/ha, não houve efeito de tamanho de tubérculos na biomassa fresca ou seca de raiz. Dados obtidos por Lafond 
\& Baker (1986) com nove cultivares de trigo também comprovaram que a produção de matéria seca é maior quando as plantas são originadas de semente de tamanho grande. Procópio et al. (2001) observaram que o acúmulo de biomassa seca de raízes de plantas de feijão aumentou com o uso de sementes maiores. Edwards Junior \& Hartwig (1971) observaram que em plantas de soja oriundas de sementes de tamanho pequeno (9,5 g/100 sementes) e médio (13,6 g/100 sementes), emergem mais rapidamente e apresentam maior desenvolvimento radicular que as de tamanho grande. Entretanto, deve-se considerar que a habilidade da planta translocar e utilizar as reservas podem exercer influência no tamanho e na biomassa das plântulas. Não foi observada interação entre esses dois fatores para biomassa fresca e seca de rizomas (dados não apresentados).

Tabela 8. Efeito da interação entre quantidade de palha adicionada e tamanho de tubérculos da tiririca nas biomassas frescas de raiz, total de tubérculos e parte subterrânea total

\begin{tabular}{|c|c|c|c|c|c|c|c|}
\hline \multirow{3}{*}{$\begin{array}{l}\text { Tamanho } \\
\text { dos } \\
\text { tuberc. }\end{array}$} & \multicolumn{7}{|c|}{ Biomassa fresca raiz (g) } \\
\hline & \multicolumn{4}{|c|}{ Quantidade de palha } & \multirow[t]{2}{*}{ Médias } & \multirow{2}{*}{\multicolumn{2}{|c|}{$\begin{array}{l}\text { Equações de ajuste e } \\
\text { coeficiente de determinação }{ }^{1}\end{array}$}} \\
\hline & $0,0 \mathrm{t} / \mathrm{ha}$ & $5,0 t / h a$ & $10,0 t / h a$ & $15,0 t / h a$ & & & \\
\hline Pequeno & $14,49 \mathrm{~b}^{2}$ & $12,38 \mathrm{a}$ & $10,86 \mathrm{~b}$ & $11,75 \mathrm{~b}$ & $12,37 \mathrm{~b}$ & $Y=14,58-0,644 x+0,030 x^{2}$ & $7,66 \%$ \\
\hline Grande & $19,24 \mathrm{a}$ & $12,95 \mathrm{a}$ & $12,69 \mathrm{a}$ & $15,08 \mathrm{a}$ & $14,99 a$ & $Y=19,07-1,56 x+0,087 x^{2}$ & $\mathrm{R}^{2}=97,94 \%$ \\
\hline Tamanho & \multicolumn{7}{|c|}{ Biomassa fresca de total de tubérculos $(\mathrm{g})$} \\
\hline dos & \multicolumn{4}{|c|}{ Quantidade de palha } & Médias & \multirow{2}{*}{\multicolumn{2}{|c|}{$\begin{array}{l}\text { Equações de ajuste e } \\
\text { coeficiente de determinação }{ }^{1}\end{array}$}} \\
\hline tuberc. & $0,0 \mathrm{t} / \mathrm{ha}$ & $5,0 t / h a$ & $10,0 t / h a$ & $15,0 t / h a$ & & & \\
\hline Pequeno & $12,82 b^{2}$ & $11,34 \mathrm{~b}$ & $11,30 \mathrm{~b}$ & $11,78 \mathrm{~b}$ & $11,81 b$ & $Y=12,77-0,36 x+0,020 x^{2}$ & $\mathrm{R}^{2}=97,15 \%$ \\
\hline Grande & 20,19 a & $15,67 \mathrm{a}$ & $16,43 \mathrm{a}$ & 17,05 a & $17,33 a$ & $Y=19,92-0,94 x+0,052 x^{2}$ & $\mathrm{R}^{2}=87,59 \%$ \\
\hline Tamanho & \multicolumn{7}{|c|}{ Biomassa fresca de parte subterrânea total $(\mathrm{g})$} \\
\hline dos & \multicolumn{4}{|c|}{ Quantidade de palha } & Médias & \multirow{2}{*}{\multicolumn{2}{|c|}{$\begin{array}{l}\text { Equações de ajuste e } \\
\text { coeficiente de determinação }{ }^{1}\end{array}$}} \\
\hline tuberc. & $0,0 \mathrm{t} / \mathrm{ha}$ & $5,0 \mathrm{t} / \mathrm{ha}$ & $10,0 \mathrm{t} / \mathrm{ha}$ & $15,0 t / h a$ & & & \\
\hline Pequeno & $34,67 b^{2}$ & $27,40 \mathrm{~b}$ & $25,61 \mathrm{~b}$ & $27,06 \mathrm{~b}$ & $28,69 b$ & $Y=34,56-1,80 x+0,087 x^{2}$ & $\mathrm{R}^{2}=99,49 \%$ \\
\hline Grande & 45,72 a & 32,77 a & $32,53 \mathrm{a}$ & 35,43 a & $36,61 \mathrm{a}$ & $Y=45,24-2,996 x+0,16 x^{2}$ & $\mathrm{R}^{2}=96,05 \%$ \\
\hline
\end{tabular}

1. Equações de regressão e coeficientes de determinação para o efeito da quantidade de palha adicionada dentro de cada tamanho de tubérculo.

2. Médias seguidas por letras iguais na coluna, que comparam o efeito do tamanho de tubérculos para cada quantidade de palha adicionada, não diferem entre si pelo teste de Tukey a $5 \%$. 
Tabela 9. Efeito da interação entre quantidade de palha adicionada ao solo e tamanho de tubérculos da tiririca nas biomassas secas de raiz, total de tubérculos e parte subterrânea total

\begin{tabular}{|c|c|c|c|c|c|c|c|}
\hline \multirow{3}{*}{$\begin{array}{l}\text { Tamanho } \\
\text { tuberc. }\end{array}$} & \multicolumn{7}{|c|}{ Biomassa seca de raiz (g) } \\
\hline & \multicolumn{4}{|c|}{ Quantidade de palha } & \multirow[t]{2}{*}{ Médias } & \multirow{2}{*}{\multicolumn{2}{|c|}{$\begin{array}{l}\text { Equações de ajuste e } \\
\text { coeficiente de determinação }{ }^{1}\end{array}$}} \\
\hline & $0,0 \mathrm{t} / \mathrm{ha}$ & $5,0 \mathrm{t} / \mathrm{ha}$ & $10,0 \mathrm{t} / \mathrm{ha}$ & $15,0 t / h a$ & & & \\
\hline Pequeno & $1,51 \mathrm{~b}^{2}$ & $1,19 \mathrm{a}$ & $1,16 \mathrm{~b}$ & $1,20 \mathrm{~b}$ & $1,27 \mathrm{~b}$ & $Y=1,50-0,075 x+0,004 x^{2}$ & $\mathrm{R}^{2}=96,95 \%$ \\
\hline \multirow[t]{2}{*}{ Grande } & $2,12 \mathrm{a}$ & $1,37 \mathrm{a}$ & $1,48 \mathrm{a}$ & $1,51 \mathrm{a}$ & $1,62 \mathrm{a}$ & $Y=2,08-0,15 x+0,0078 x^{2}$ & $\mathrm{R}^{2}=87,45 \%$ \\
\hline & \multicolumn{7}{|c|}{ Biomassa seca de total de tubérculos (g) } \\
\hline Tamanho & \multicolumn{4}{|c|}{ Quantidade de palha } & Médias & \multirow{2}{*}{\multicolumn{2}{|c|}{$\begin{array}{l}\text { Equações de ajuste e } \\
\text { coeficiente de determinação }{ }^{1}\end{array}$}} \\
\hline tuberc. & $0,0 \mathrm{t} / \mathrm{ha}$ & $5,0 \mathrm{t} / \mathrm{ha}$ & $10,0 \mathrm{t} / \mathrm{ha}$ & $15,0 t / h a$ & & & \\
\hline Pequeno & $3,76 b^{2}$ & $3,62 \mathrm{~b}$ & $3,63 \mathrm{~b}$ & $3,88 \mathrm{~b}$ & $3,72 b$ & \multicolumn{2}{|c|}{ Não significativo } \\
\hline \multirow[t]{2}{*}{ Grande } & $6,31 \mathrm{a}$ & $5,20 \mathrm{a}$ & $5,56 \mathrm{a}$ & $5,82 \mathrm{a}$ & $5,72^{\mathrm{a}}$ & $Y=6,23-0,23 x+, 014 x^{2}$ & $\mathrm{R}^{2}=81,05 \%$ \\
\hline & \multicolumn{7}{|c|}{ Biomassa seca de parte subterrânea total (g) } \\
\hline Tamanho & \multicolumn{4}{|c|}{ Quantidade de palha } & Médias & \multirow{2}{*}{\multicolumn{2}{|c|}{$\begin{array}{l}\text { Equações de ajuste e } \\
\text { coeficiente de determinação }{ }^{1}\end{array}$}} \\
\hline tuberc. & $0,0 \mathrm{t} / \mathrm{ha}$ & $5,0 \mathrm{t} / \mathrm{ha}$ & $10,0 t / h a$ & $15,0 t / h a$ & & & \\
\hline Pequeno & $6,87 b^{2}$ & $5,72 \mathrm{~b}$ & $5,75 \mathrm{~b}$ & $6,00 \mathrm{~b}$ & $6,09 b$ & $Y=6,87-0,26 x+0,014 x^{2}$ & $\mathrm{R}^{2}=94,53 \%$ \\
\hline Grande & 10,18 a & $7,74 \mathrm{a}$ & $8,08 \mathrm{a}$ & $8,53 \mathrm{a}$ & $8,64 a$ & $Y=10,05-0,053 x+0,029 x^{2}$ & $\mathrm{R}^{2}=89,87 \%$ \\
\hline
\end{tabular}

1. Equações de regressão e coeficientes de determinação para o efeito da quantidade de palha adicionada dentro de cada tamanho de tubérculo de tiririca.

2. Médias seguidas por letras iguais na coluna, que comparam o efeito do tamanho de tubérculos para cada quantidade de palha adicionada, não diferem entre si pelo teste de Tukey a $5 \%$.

Houve efeito depressivo para as biomassas fresca e seca de raiz, total de tubérculos e parte subterrânea total com a adição de palha. Observou-se que as equações que melhor se ajustaram às quantidades de palha adicionadas foram as de segundo grau. De modo geral, o efeito foi mais pronunciado em plantas provenientes de tubérculos grandes para os quais com quantidades menores de palha a redução foi maior (Tabelas 8 e 9).

O resultado da interação entre tamanho de tubérculos e época de amostragem são apresentados nas Figuras 3 e 4 . As biomassas fresca e seca de total de tubérculos, as secas de rizomas e da parte subterrânea total, nas diferentes épocas de avaliação, para ambos os tamanhos de tubérculos, aumentaram linearmente em função do tempo. Jordan-Molero \& Stoller (1978) também observaram aumento linear no acúmulo de matéria seca da tiririca em função do tempo. Entretanto, essas mesmas biomassas em todas as épocas analisadas foram maiores em plantas oriundas de tubérculos grandes. 

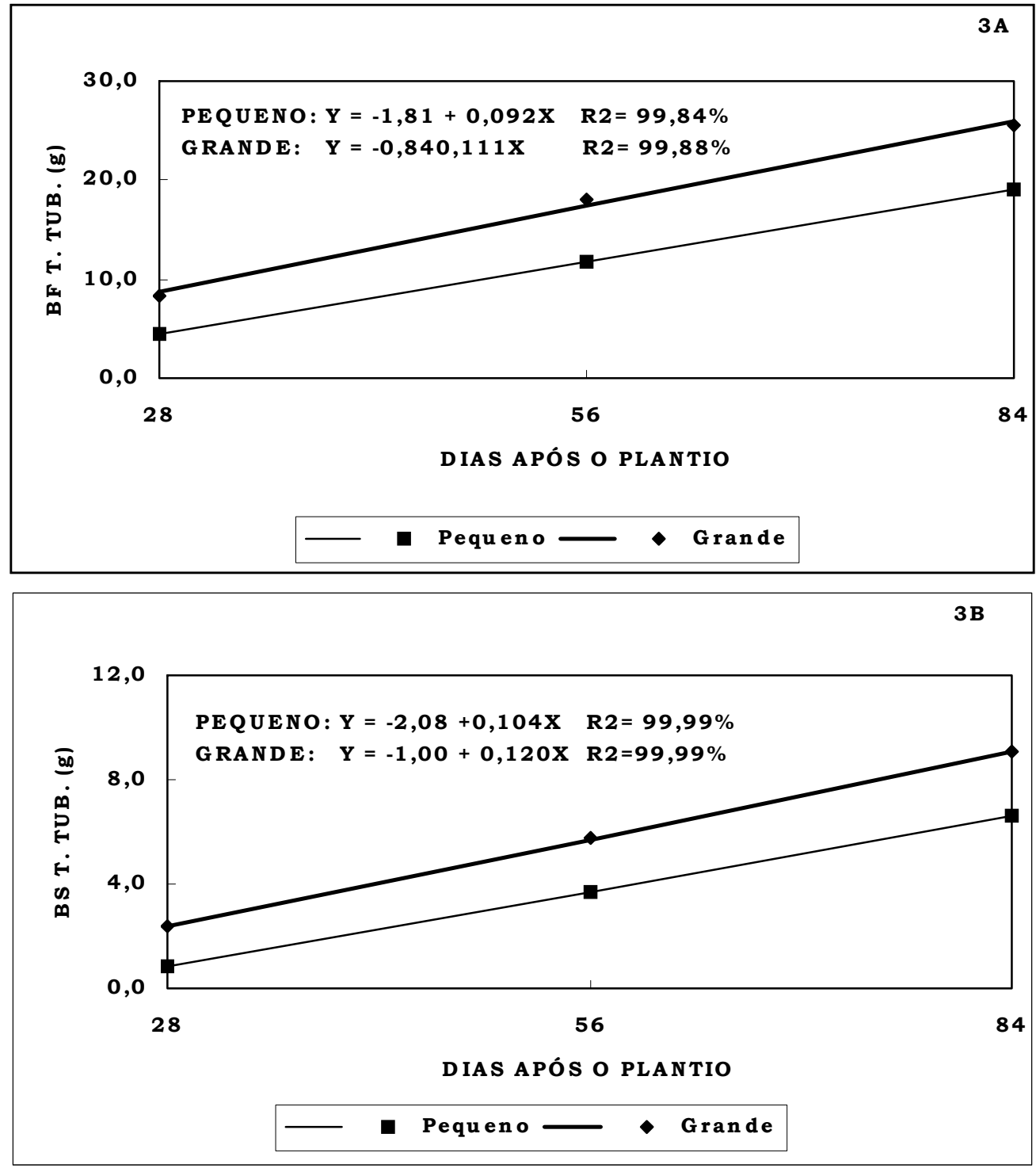

Figura 3 - Efeito da interação entre tamanho de tubérculos e épocas de avaliação para biomassas fresca (BF) e seca (BS) de total de tubérculos em Campinas, 2003 

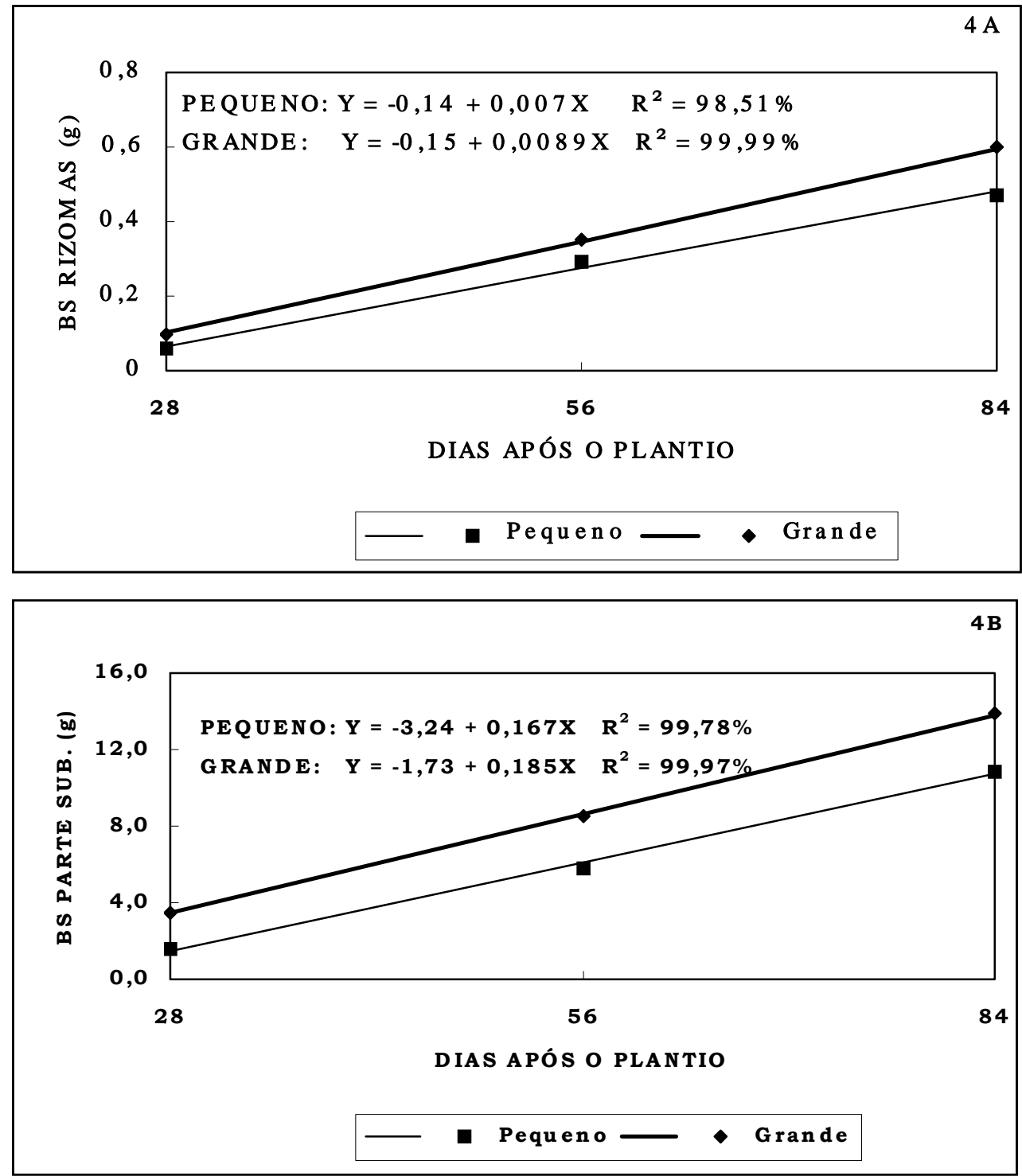

Figura 4 - Efeito da interação entre tamanho de tubérculos e épocas de avaliação para biomassas seca (BS) de rizomas e parte subterrânea total. de tiririca em Campinas, SP 
Tabela 10. Efeito da interação entre à adição de palha e épocas de plantio dos tubérculos de tiririca nas biomassas frescas de raiz, rizomas, total de tubérculos e parte subterrânea total

\begin{tabular}{|c|c|c|c|c|c|c|}
\hline \multirow{4}{*}{$\begin{array}{l}\text { Época de } \\
\text { plantio } \\
\text { tubérculo } \\
\text { Maio }\end{array}$} & \multicolumn{6}{|c|}{ Biomassa fresca de raiz } \\
\hline & \multicolumn{4}{|c|}{ Quantidade de palha } & \multirow{2}{*}{\multicolumn{2}{|c|}{$\begin{array}{l}\text { Equações de ajuste e } \\
\text { coeficiente de determinação }{ }^{1}\end{array}$}} \\
\hline & $0,0 \mathrm{t} / \mathrm{ha}$ & $5,0 \mathrm{t} / \mathrm{ha}$ & $10,0 \mathrm{t} / \mathrm{ha}$ & $15,0 t /$ ha & & \\
\hline & $14,94 \mathrm{~b}^{2}$ & $12,05 \mathrm{~b}$ & $12,32 \mathrm{~b}$ & $14,39 \mathrm{~b}$ & $Y=14,86-0,77 x+0,045 x^{2}$ & $\mathrm{R}^{2}=98,53 \%$ \\
\hline Julho & $6,12 \mathrm{c}$ & $7,30 \mathrm{c}$ & $7,54 \mathrm{c}$ & $9,04 \mathrm{c}$ & $Y=6,15-0,18 x$ & $\mathrm{R}^{2}=93,88 \%$ \\
\hline Setembro & 29,54 a & 18,65 a & $15,45 \mathrm{a}$ & $16,81 \mathrm{a}$ & $Y=29,39-0,67 x+0,123 x^{2}$ & $\mathrm{R}^{2}=99,60 \%$ \\
\hline Época de & \multicolumn{6}{|c|}{ Biomassa fresca de rizoma } \\
\hline plantio & \multicolumn{4}{|c|}{ Quantidade de palha } & \multirow{2}{*}{\multicolumn{2}{|c|}{$\begin{array}{l}\text { Equações de ajuste e } \\
\text { coeficiente de determinação }{ }^{1}\end{array}$}} \\
\hline tubérculo & $0,0 \mathrm{t} / \mathrm{ha}$ & $5,0 \mathrm{t} / \mathrm{ha}$ & $10,0 \mathrm{t} / \mathrm{ha}$ & $15,0 t /$ ha & & \\
\hline Maio & $3,18 b^{2}$ & $2,42 \mathrm{~b}$ & $2,23 \mathrm{~b}$ & $2,77 \mathrm{a}$ & $Y=3,19-0,22 x+0,013 x^{2}$ & $\mathrm{R}^{2}=99,76 \%$ \\
\hline Julho & $0,82 \mathrm{c}$ & $0,85 \mathrm{c}$ & $1,08 \mathrm{c}$ & $1,27 \mathrm{~b}$ & $Y=0,76+0,032 x$ & $\mathrm{R}^{2}=93,61 \%$ \\
\hline Setembro & $5,73 \mathrm{a}$ & $3,40 \mathrm{a}$ & 2,79 a & $2,51 \mathrm{a}$ & $Y=5,66-0,52 x+0,021 x^{2}$ & $\mathrm{R}^{2}=98,48 \%$ \\
\hline Época de & \multicolumn{6}{|c|}{ Biomassa fresca de total de tubérculos } \\
\hline plantio & \multicolumn{4}{|c|}{ Quantidade de palha } & \multirow{2}{*}{\multicolumn{2}{|c|}{$\begin{array}{l}\text { Equações de ajuste e } \\
\text { coeficiente de determinação }^{1}\end{array}$}} \\
\hline tubérculo & $0,0 \mathrm{t} / \mathrm{ha}$ & $5,0 \mathrm{t} / \mathrm{ha}$ & $10,0 \mathrm{t} / \mathrm{ha}$ & $15,0 t /$ ha & & \\
\hline Maio & $19,70 \mathrm{~b}^{2}$ & 16,64 a & $18,63 \mathrm{a}$ & 20,18 a & $Y=19,43-0,62 x+0,046 x^{2}$ & $R^{2}=96,06 \%$ \\
\hline Julho & $7,21 \mathrm{c}$ & $6,51 \mathrm{~b}$ & $7,73 \mathrm{c}$ & $8,52 \mathrm{~b}$ & $Y=6,71+0,10 x$ & $\mathrm{R}^{2}=61,62 \%$ \\
\hline Setembro & 22,62 a & 17,36 a & $15,22 \mathrm{~b}$ & $14,54 \mathrm{~b}$ & $Y=21,39-0,53 x$ & $\mathrm{R}^{2}=86,65 \%$ \\
\hline Época de & \multicolumn{6}{|c|}{ Biomassa fresca de parte subterrânea total } \\
\hline plantio & \multicolumn{4}{|c|}{ Quantidade de palha } & \multirow{2}{*}{\multicolumn{2}{|c|}{$\begin{array}{l}\text { Equações de ajuste e } \\
\text { coeficiente de determinação }{ }^{1}\end{array}$}} \\
\hline tubérculo & $0,0 \mathrm{t} / \mathrm{ha}$ & $5,0 \mathrm{t} / \mathrm{ha}$ & $10,0 \mathrm{t} / \mathrm{ha}$ & $15,0 t /$ ha & & \\
\hline Maio & $34,52 \mathrm{~b}^{2}$ & $28,44 \mathrm{~b}$ & $29,65 \mathrm{~b}$ & $32,80 \mathrm{~b}$ & $Y=34,25-1,463 x+0,092 x^{2}$ & $\mathrm{R}^{2}=93,92 \%$ \\
\hline Julho & $14,40 \mathrm{c}$ & $14,49 \mathrm{c}$ & $16,74 \mathrm{c}$ & $19,16 \mathrm{c}$ & $Y=13,72+0,33 x$ & $\mathrm{R}^{2}=89,73 \%$ \\
\hline Setembro & 71,67 a & 47,33 a & 40,82 a & 41,77 a & $Y=71,15-5,72 x+0,23 x^{2}$ & $\mathrm{R}^{2}=99,14 \%$ \\
\hline
\end{tabular}

1 Equações de regressão e coeficientes de determinação para o efeito da quantidade de palha adicionada dentro de cada época de plantio dos tubérculos de tiririca.

2 Médias seguidas por letras iguais na coluna, que comparam o efeito da época de plantio dos tubérculos de tiririca para cada quantidade de palha adicionada, não diferem entre si pelo teste de Tukey a $5 \%$.

As interações entre adição de palha e época de plantio de tubérculos quanto à biomassa fresca e seca das estruturas subterrâneas são apresentadas, respectivamente, nas Tabelas 10 e 11 . As biomassas frescas de raiz, rizomas e parte subterrânea total, para quaisquer das quantidades de palha, foram maiores nos plantio de setembro e menor em julho (Tabela 10). Foi observado maior biomassa 
fresca de total de tubérculo no plantio de setembro apenas no tratamento sem palha. Com a adição de 10,0 e 15,0 t/ha de palha, foi observada maior biomassa fresca de total de tubérculo no plantio de maio. No plantio de julho, com qualquer quantidade de palha adicionada, propiciou menor biomassa fresca de total de tubérculo.

Nos plantios de maio e setembro, observou-se que com a adição de palha, houve redução nas biomassas fresca de raiz, rizomas e parte subterrânea total de acordo com uma equação do segundo grau. Azania et al. (2002) observaram que há redução no número de plantas daninhas em áreas cobertas com quantidades de palha superiores a 3,0 t/ha o que também foi observado por Martins et al. (1999).

As biomassas frescas de raiz, rizoma, total de tubérculos e parte subterrânea total aumentaram linearmente com a adição de palha quando plantados em julho. Fernandes-Quintanilla (1978) e Vidal \& Theisen (1999) observaram que em áreas cobertas com resíduos vegetais, há menor incidência de luz e menor aquecimento do solo o que pode interferir no desenvolvimento da planta influenciando nas diferentes etapas do ciclo de vida como na germinação, estabelecimento e reprodução da espécie. Entretanto, em solo coberto também é observada menores perda de calor e de oscilação térmica. Miles et al. (1996) observaram estímulo na brotação da tiririca quando houve oscilação térmica de 2 a $6^{\circ} \mathrm{C}$. Com menor oscilação térmica, como a do plantio de julho nos vasos com palha, houve menores brotação e biomassa que as das outras épocas de instalação mas as plantas que brotaram em função da maior temperatura observada no solo coberto que no sem palha, tiveram suas biomassas linearmente aumentadas. A biomassa fresca de tubérculos foi linearmente reduzida com a adição de palha no plantio de setembro.

A biomassa seca de raiz foi maior no plantio de setembro e menor em julho com qualquer quantidade de palha adicionada (Tabela 11). O mesmo ocorreu com a biomassa seca de rizoma e de parte subterrânea total até a adição de 10,0 t/ ha palha. Com 15,0 t/ha de palha, não houve diferença para biomassa seca de rizomas entre o plantio de setembro e de maio mas o de julho produziu biomassa menor.

Para biomassa seca de total de tubérculos, verificou-se que no tratamento sem palha, o plantio de setembro propiciou biomassas superiores ao de maio (Tabela 11). Entretanto, com 10,0 t/ha não houve diferença entre o plantio de maio e setembro e com 5,0 e 15,0 t/ha, a biomassa foi maior no plantio de setembro e de maio, respectivamente. Para quaisquer das quantidades de palha adicionadas, o plantio de julho foi o que propiciou menores biomassas de total de tubérculos. Hammerton (1975b) observou que em condição de clima tropical, temperaturas médias mais altas 
como as que ocorrem em setembro, estimulam as plantas de tiririca a distribuir mais biomassa seca para os tubérculos mas o mesmo não ocorreu nas condições do experimento quando foi adicionado palha na superficie do solo. Friesen \& Hamill (1977) observaram que para C. esculentus a umidade do solo afetava o desenvolvimento da planta. Em condições de solo seco e em época que a pluviosidade é baixa, os tubérculos tornam-se dormentes e sua periodicidade para germinar e desenvolver novos tubérculos é imprevisivel. Em condições de solo úmido e precipitação regular os tubérculos desenvolvem-se rapidamente com o favorecimento da temperatura. Assim, a umidade do solo e a chuva podem ser usados como indicadores para planejar e adotar medidas de controle mais eficientes. Holt \& Orcutt (1996) classificaram a tiririca como planta $\mathrm{C}_{4}$ por ser altamente competitiva nos períodos em que a temperatura e a intensidade luminosa são elevadas quando a maioria das culturas tornam-se estressadas, fato que ocorre principalmente no verão (Jackson, 1997). Quando os dias são curtos e secos, ocasião em que a maioria das culturas não se desenvolve, a tiririca forma tubérculos.

Em relação ao efeito de adição de palha em cada época de plantio, verificou-se que, as biomassas secas de raiz e de rizomas de tubérculos plantados em maio e setembro seguiram uma equação do segundo grau atingindo valores mínimos com a adição de palha na faixa entre 7,8 e 12,2 t/ha (Tabela 11). Para as biomassas secas de total de tubérculos e parte subterrânea total, verificou-se que no plantio de maio, os menores valores foram obtidos com, respectivamente, 4,3 e 6,1 t/ha. No plantio de julho, a adição de palha favoreceu a formação da parte subterrânea, sendo observado aumento linear para quaisquer das estruturas analisadas. No plantio de setembro verificou-se redução linear nas biomassas secas de total de tubérculos e da parte subterrânea total.

Para o efeito de época de amostragem dentro de cada quantidade de palha adicionada, verificou-se que apenas para biomassa seca de raiz não foi observada interação significativa. (dados não apresentados). As biomassas fresca de raiz e frescas e secas de rizomas (Figura 5), total de tubérculos e parte subterrânea total (Figura 6 e 7), para quaisquer das quantidades de palha adicionadas aumentaram linearmente em função do tempo. 
Tabela 11. Efeito da interação entre à adição de palha e épocas de plantio dos tubérculos de tiririca nas biomassas secas de raiz, rizomas, total de tubérculos e parte subterrânea total

\begin{tabular}{|c|c|c|c|c|c|c|}
\hline \multirow{4}{*}{$\begin{array}{l}\text { Época de } \\
\text { plantio } \\
\text { tubérculo } \\
\text { Maio }\end{array}$} & \multicolumn{6}{|c|}{ Biomassa seca de raiz (g) } \\
\hline & \multicolumn{4}{|c|}{ Quantidade de palha } & \multirow{2}{*}{\multicolumn{2}{|c|}{$\begin{array}{l}\text { Equações de ajuste e } \\
\text { coeficiente de determinação }{ }^{1}\end{array}$}} \\
\hline & $0,0 \mathrm{t} / \mathrm{ha}$ & $5,0 \mathrm{t} / \mathrm{ha}$ & $10,0 \mathrm{t} / \mathrm{ha}$ & $15,0 t /$ ha & & \\
\hline & $1,81 \mathrm{~b}^{2}$ & $1,16 \mathrm{~b}$ & $1,52 \mathrm{a}$ & $1,58 \mathrm{a}$ & $Y=1,74-0,11 x+0,0071 x$ & $\mathrm{R}^{2}=60,29 \%$ \\
\hline Julho & $0,63 \mathrm{c}$ & $0,69 \mathrm{c}$ & $0,87 \mathrm{~b}$ & $0,89 \mathrm{~b}$ & $Y=0,63+0,019 x$ & $\mathrm{R}^{2}=90,46 \%$ \\
\hline Setembro & 3,02 a & $2,00 \mathrm{a}$ & $1,57 \mathrm{a}$ & $1,61 \mathrm{a}$ & $Y=3,01-0,25 x+0,011 x^{2}$ & $\mathrm{R}^{2}=99,95 \%$ \\
\hline Época de & \multicolumn{6}{|c|}{ Biomassa seca de rizomas (g) } \\
\hline plantio & \multicolumn{4}{|c|}{ Quantidade de palha } & \multirow{2}{*}{\multicolumn{2}{|c|}{$\begin{array}{l}\text { Equações de ajuste e } \\
\text { coeficiente de determinação }{ }^{1}\end{array}$}} \\
\hline tubérculo & $0,0 \mathrm{t} / \mathrm{ha}$ & $5,0 \mathrm{t} / \mathrm{ha}$ & $10,0 \mathrm{t} / \mathrm{ha}$ & $15,0 t / h a$ & & \\
\hline Maio & $0,40 b^{2}$ & $0,26 \mathrm{~b}$ & $0,28 \mathrm{~b}$ & $0,36 \mathrm{a}$ & $Y=0,39-0,036 x+0,0023 x^{2}$ & $\mathrm{R}^{2}=96,45 \%$ \\
\hline Julho & $0,11 \mathrm{c}$ & $0,11 \mathrm{c}$ & $0,15 \mathrm{c}$ & $0,17 \mathrm{~b}$ & $Y=0,11+0,0044 x$ & $\mathrm{R}^{2}=92,09 \%$ \\
\hline Setembro & $0,78 \mathrm{a}$ & $0,44 \mathrm{a}$ & $0,36 \mathrm{a}$ & $0,32 \mathrm{a}$ & $Y=0,71-0,076 x+0,0031 x^{2}$ & $\mathrm{R}^{2}=98,04 \%$ \\
\hline Época de & \multicolumn{6}{|c|}{ Biomassa seca de total de tubérculos (g) } \\
\hline plantio & \multicolumn{4}{|c|}{ Quantidade de Palha } & \multirow{2}{*}{\multicolumn{2}{|c|}{$\begin{array}{l}\text { Equações de ajuste e } \\
\text { coeficiente de determinação }{ }^{1}\end{array}$}} \\
\hline tubérculo & $0,0 \mathrm{t} / \mathrm{ha}$ & $5,0 \mathrm{t} / \mathrm{ha}$ & $10,0 \mathrm{t} / \mathrm{ha}$ & $15,0 t /$ ha & & \\
\hline Maio & $5,54 \mathrm{~b}^{2}$ & $5,07 \mathrm{~b}$ & $5,81 \mathrm{a}$ & 6,43 a & $Y=5,48-0,095 x+0,011 x^{2}$ & $\mathrm{R}^{2}=90,74 \%$ \\
\hline Julho & $2,15 \mathrm{c}$ & $2,27 \mathrm{c}$ & $2,59 \mathrm{~b}$ & $2,84 \mathrm{c}$ & $Y=2,11+0,047 x$ & $\mathrm{R}^{2}=97,23 \%$ \\
\hline Setembro & 7,40 a & 5,88 a & 5,39 a & $5,28 \mathrm{~b}$ & $Y=7,02-0,14 x$ & $\mathrm{R}^{2}=82,15 \%$ \\
\hline Época de & \multicolumn{6}{|c|}{ Biomassa seca de parte subterrânea total (g) } \\
\hline plantio & \multicolumn{4}{|c|}{ Quantidade de palha } & \multirow{2}{*}{\multicolumn{2}{|c|}{$\begin{array}{l}\text { Equações de ajuste e } \\
\text { coeficiente de determinação }^{1}\end{array}$}} \\
\hline tubérculo & $0,0 \mathrm{t} / \mathrm{ha}$ & $5,0 \mathrm{t} / \mathrm{ha}$ & $10,0 \mathrm{t} / \mathrm{ha}$ & $15,0 t /$ ha & & \\
\hline Maio & $8,09 \mathrm{~b}^{2}$ & $6,81 \mathrm{~b}$ & $7,87 \mathrm{~b}$ & $8,78 \mathrm{ab}$ & $Y=7,96-0,27 x+0,022 x^{2}$ & $\mathrm{R}^{2}=84,50 \%$ \\
\hline Julho & $3,23 \mathrm{c}$ & $3,53 \mathrm{c}$ & $4,02 \mathrm{c}$ & $4,38 \mathrm{~b}$ & $Y=3,20+0,079 x$ & $\mathrm{R}^{2}=99,21 \%$ \\
\hline Setembro & 14,26 a & 9,86 a & 8,87 a & $8,64 \mathrm{a}$ & $Y=13,08-0,37 x$ & $\mathrm{R}^{2}=77,13 \%$ \\
\hline
\end{tabular}

1 Equações de regressão e coeficientes de determinação para o efeito da quantidade de palha adicionada dentro de cada época de plantio dos tubérculos de tiririca.

2 Médias seguidas por letras iguais na coluna, que comparam o efeito da época do plantio dos tubérculos de tiririca para cada quantidade de palha adicionada, não diferem entre si pelo teste de Tukey a $5 \%$.

Verificou-se que no plantio de maio, julho e setembro as biomassas frescas e secas de raiz, rizomas, total de tubérculo e parte subterrânea total aumentaram linearmente em função do tempo (Tabela 12). Na amostragem aos 28 dias verificou-se que as biomassas fresca de raiz, rizomas e parte subterrânea total foram estatísticamente iguais nos plantio realizados em maio e setembro, sendo observado os menores valores em julho. Aos 56 e 84 dias, as biomassas fresca de raiz, rizomas e 
parte subterrânea total foram maiores no plantio de setembro e menores em julho. A biomassa fresca de total de tubérculos, em qualquer época de avaliação foi estatísticamente igual no plantio de setembro e maio e menor em julho (Tabela 12).

A biomassa seca de raiz, em qualquer época de avaliação, foi estatísticamente superior no plantio de setembro e menor em julho (Tabela 13). O mesmo foi observado para as biomassas secas de rizomas e parte subterrânea total nas avaliações realizadas aos 56 e 84 dias. Aos 28 dias, a biomassa seca de rizoma foi maior em maio. Aos 28 e 56 dias, a biomassa seca do total de tubérculos foi igual nos plantios de maio e setembro mas, aos 84 dias, foi maior na instalação de setembro.

\subsection{Conclusões}

Concluiu-se que:

1) De maneira geral, o tamanho maior dos tubérculos favoreceu o desenvolvimento da parte subterrânea sendo observado que plantas originadas de tubérculos de tamanho grande apresentaram maiores biomassas fresca e seca.

2) A adição de quantidades crescentes de palha de cana-de-açúcar causou redução no desenvolvimento das diferentes estruturas subterrâneas seguindo, para todas as variáveis, uma equação de segundo grau.

3) Para o efeito de época de amostragem foram observados aumentos lineares em função do tempo para todas as variáveis analisadas. 

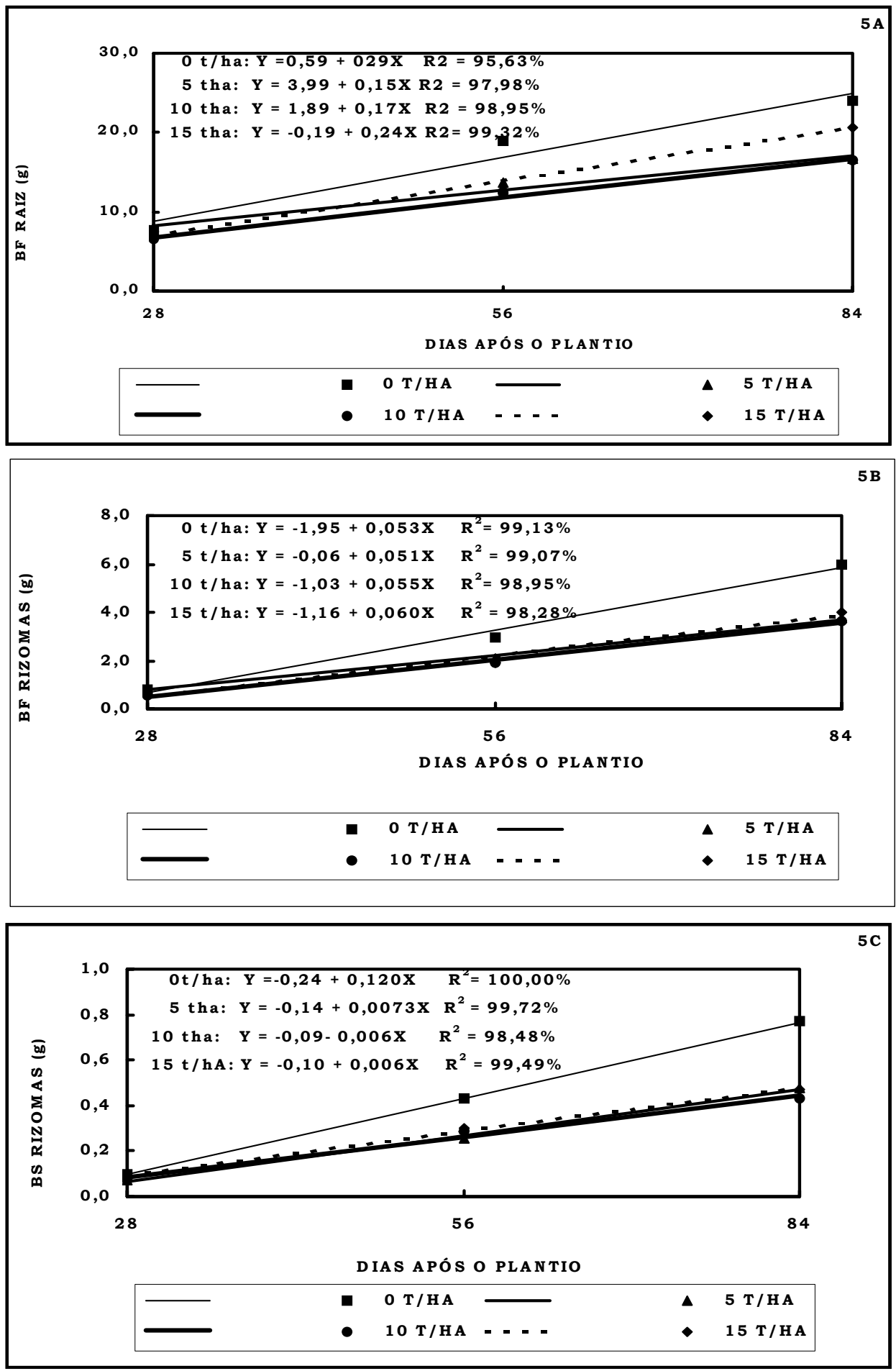

Figura 5 - Efeito da época de amostragem para cada quantidade de palha adicionada quanto às biomassas fresca $(\mathrm{BF})$ de raiz, e fresca e seca (BS) de rizomas de tiririca 

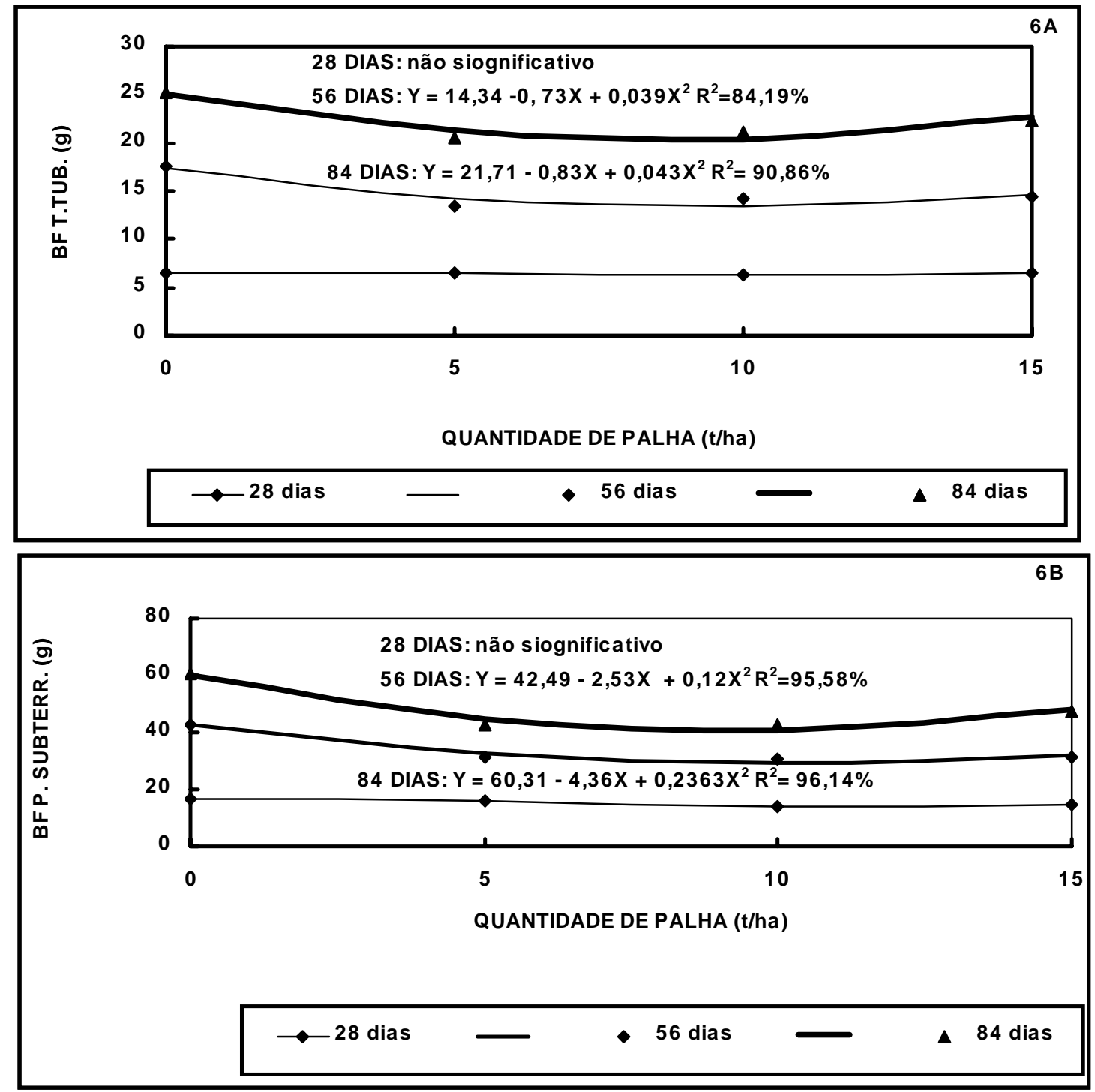

Figura 6 - Efeito da época de amostragem para cada quantidade de palha adicionada quanto às biomassas fresca $(\mathrm{BF})$ de total de tubérculos e parte subterrânea total de tiririca 

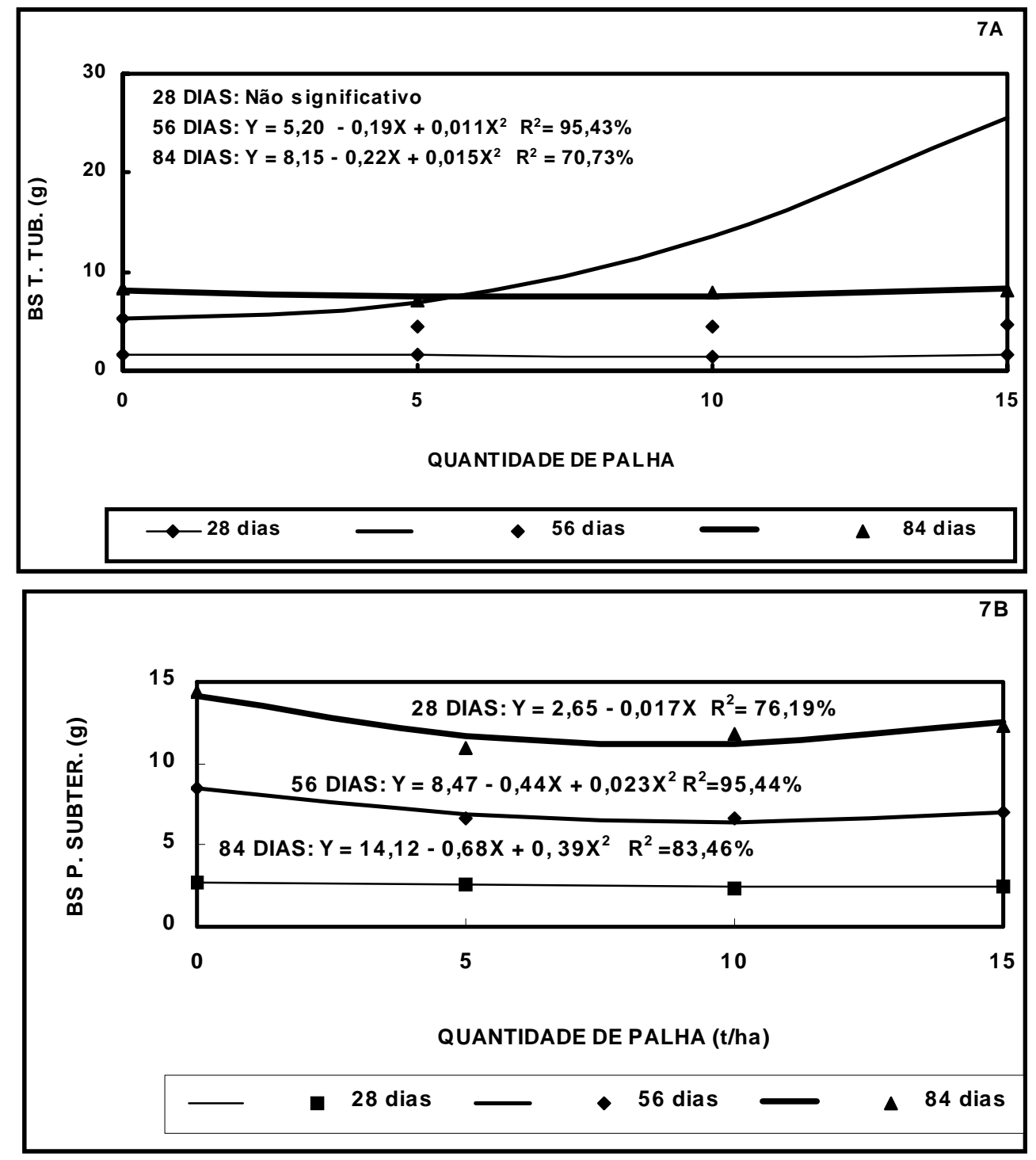

Figura 7 - Efeito da época de amostragem para cada quantidade de palha adicionada quanto às biomassas seca (BS) de total de tubérculos e parte subterrânea total de tiririca 
Tabela 12. Efeito da interação entre época de amostragem e época de plantio dos tubérculos de tiririca nas biomassas frescas de raiz, rizomas, total de tubérculos e parte subterrânea total

\begin{tabular}{|c|c|c|c|c|c|}
\hline \multirow{3}{*}{$\begin{array}{l}\text { Época de } \\
\text { plantio } \\
\text { Maio }\end{array}$} & \multicolumn{3}{|c|}{ Biomassa fresca de raiz (g) } & \multirow{2}{*}{\multicolumn{2}{|c|}{$\begin{array}{c}\text { Equações de ajuste e } \\
\text { coeficiente de determinação }^{1}\end{array}$}} \\
\hline & \multirow{2}{*}{$\frac{28 \text { dias }}{8,37 \mathrm{a}^{2}}$} & \multirow{2}{*}{$\begin{array}{l}56 \text { dias } \\
12,62 \mathrm{~b}\end{array}$} & \multirow{2}{*}{$\begin{array}{l}84 \text { dias } \\
19,29 \mathrm{~b}\end{array}$} & & \\
\hline & & & & $Y=2,51+0,295 x$ & $\mathrm{R}^{2}=98,36 \%$ \\
\hline Julho & $4,00 \mathrm{~b}$ & $7,11 \mathrm{c}$ & $11,40 \mathrm{c}$ & $Y=0,11+0,132 x$ & $\mathrm{R}^{2}=99,15 \%$ \\
\hline Setembro & $9,50 \mathrm{a}$ & $23,32 \mathrm{a}$ & $27,52 \mathrm{a}$ & $Y=2,09+0,32 x$ & $\mathrm{R}^{2}=91,35 \%$ \\
\hline Época de & \multicolumn{3}{|c|}{ Biomassa fresca de rizomas (g) } & \multirow{2}{*}{\multicolumn{2}{|c|}{$\begin{array}{l}\text { Equações de ajuste e } \\
\text { coeficiente de determinação }{ }^{1}\end{array}$}} \\
\hline plantio & \multirow{2}{*}{$\begin{array}{l}28 \text { dias } \\
0,92 \mathrm{a}^{2}\end{array}$} & \multirow{2}{*}{$\begin{array}{l}56 \text { dias } \\
2,40 \mathrm{~b}\end{array}$} & \multirow{2}{*}{$\begin{array}{l}84 \text { dias } \\
4,64 \mathrm{~b}\end{array}$} & & \\
\hline Maio & & & & $Y=-1,07+0,067 x$ & $\mathrm{R}^{2}=98,63 \%$ \\
\hline Julho & $0,12 \mathrm{~b}$ & $1,13 \mathrm{c}$ & $1,76 \mathrm{c}$ & $Y=-0,64+0,029 x$ & $\mathrm{R}^{2}=98,33 \%$ \\
\hline Setembro & $1,12 \mathrm{a}$ & $3,10 \mathrm{a}$ & $6,61 \mathrm{a}$ & $Y=-1,80+0,098 x$ & $\mathrm{R}^{2}=97,50 \%$ \\
\hline Época de & \multicolumn{3}{|c|}{ Biomassa fresca de total de tubérculos (g) } & \multirow{2}{*}{\multicolumn{2}{|c|}{$\begin{array}{l}\text { Equações de ajuste e } \\
\text { coeficiente de determinação }{ }^{1}\end{array}$}} \\
\hline plantio & 28 dias & 56 dias & 84 dias & & \\
\hline Maio & $9,88 \mathrm{a}^{2}$ & 18,39 a & $28,10 \mathrm{a}$ & $Y=0,56+0,33 x$ & $\mathrm{R}^{2}=99,85 \%$ \\
\hline Julho & $4,25 \mathrm{~b}$ & $7,68 \mathrm{~b}$ & $9,66 \mathrm{~b}$ & $\mathrm{Y}=1,19+0,11 \mathrm{x}$ & $\mathrm{R}^{2}=99,74 \%$ \\
\hline Setembro & 5,17 a & 18,76 a & $24,20 \mathrm{a}$ & $Y=5,76+0,41 x$ & $\mathrm{R}^{2}=99,03 \%$ \\
\hline Época de & \multicolumn{3}{|c|}{ Biomassa fresca de p. subterrânea total $(\mathrm{g})$} & \multirow{2}{*}{\multicolumn{2}{|c|}{$\begin{array}{l}\text { Equações de ajuste e } \\
\text { coeficiente de determinação }{ }^{1}\end{array}$}} \\
\hline plantio & 28 dias & 56 dias & 84 dias & & \\
\hline Maio & $19,20 \mathrm{a}^{2}$ & $35,55 \mathrm{~b}$ & $39,30 \mathrm{~b}$ & $Y=11,24+0,36 x$ & $\mathrm{R}^{2}=88,44 \%$ \\
\hline Julho & $8,30 \mathrm{~b}$ & $16,01 \mathrm{c}$ & $24,27 \mathrm{c}$ & $Y=0,23+0,29 x$ & $\mathrm{R}^{2}=99,96 \%$ \\
\hline Setembro & 18,78 a & 51,16 a & 81,26 a & $\mathrm{Y}=12,08+1,12 \mathrm{x}$ & $R^{2}=99,96 \%$ \\
\hline
\end{tabular}


Tabela 13. Efeito da interação entre época de amostragem e época de plantio dos tubérculos de tiririca nas biomassas secas de raiz, rizomas, total de tubérculos e parte subterrânea total

\begin{tabular}{|c|c|c|c|c|c|}
\hline \multirow{2}{*}{$\begin{array}{l}\text { Época de } \\
\text { plantio }\end{array}$} & \multicolumn{3}{|c|}{ Biomassa seca de raiz (g) } & \multirow{2}{*}{\multicolumn{2}{|c|}{$\begin{array}{c}\text { Equações de ajuste e } \\
\text { coeficiente de determinação }^{1}\end{array}$}} \\
\hline & 28 dias & 56 dias & 84 dias & & \\
\hline Maio & $0,68 b^{2}$ & $1,60 \mathrm{~b}$ & $2,27 \mathrm{~b}$ & $Y=-0,074+0,028 x$ & $\mathrm{R}^{2}=99,09 \%$ \\
\hline Julho & $0,33 \mathrm{c}$ & $0,81 \mathrm{c}$ & $1,17 \mathrm{c}$ & $Y-0,068+0,015 x$ & $\mathrm{R}^{2}=99,40 \%$ \\
\hline Setembro & $1,04 \mathrm{a}$ & $2,06 \mathrm{a}$ & $3,05 \mathrm{a}$ & $Y=0,033+0,036 x$ & $\mathrm{R}^{2}=99,99 \%$ \\
\hline Época de & \multicolumn{3}{|c|}{ Biomassa seca de rizomas (g) } & \multicolumn{2}{|c|}{ Equações de ajuste e } \\
\hline plantio & 28 dias & 56 dias & 84 dias & \multicolumn{2}{|c|}{ coeficiente de determinação ${ }^{1}$} \\
\hline Maio & $0,15 \mathrm{a}^{2}$ & $0,36 \mathrm{~b}$ & $0,47 \mathrm{~b}$ & $Y=0,0026+0,0057 x$ & $\mathrm{R}^{2}=97,05 \%$ \\
\hline Julho & $0,06 \mathrm{c}$ & $0,17 \mathrm{c}$ & $0,24 \mathrm{c}$ & $Y=-0,092+0,0041 x$ & $\mathrm{R}^{2}=94,70 \%$ \\
\hline Setembro & $0,09 \mathrm{~b}$ & $0,43 \mathrm{a}$ & $0,90 \mathrm{a}$ & $Y=-0,344+0,0146 x$ & $\mathrm{R}^{2}=99,18 \%$ \\
\hline Época de & \multicolumn{3}{|c|}{ Biomassa seca de total de tubérculos (g) } & \multirow{2}{*}{\multicolumn{2}{|c|}{$\begin{array}{c}\text { Equações de ajuste e } \\
\text { coeficiente de determinação }{ }^{1}\end{array}$}} \\
\hline plantio & 28 dias & 56 dias & 84 dias & & \\
\hline Maio & $2,17 \mathrm{a}^{2}$ & 5,76 a & $9,22 \mathrm{~b}$ & $Y=0,56+0,33 x$ & $\mathrm{R}^{2}=99,85 \%$ \\
\hline Julho & $1,09 \mathrm{~b}$ & $2,28 \mathrm{~b}$ & $4,01 \mathrm{c}$ & $Y=1,19+0,11 x$ & $\mathrm{R}^{2}=99,74 \%$ \\
\hline Setembro & $1,51 \mathrm{a}$ & $6,12 \mathrm{a}$ & $10,33 \mathrm{a}$ & $Y=5,76+0,41 x$ & $\mathrm{R}^{2}=99,03 \%$ \\
\hline Época de & \multicolumn{3}{|c|}{ Biomassa seca de p. subterrânea total (g) } & \multirow{2}{*}{\multicolumn{2}{|c|}{$\begin{array}{l}\text { Equações de ajuste e } \\
\text { coeficiente de determinação }{ }^{1}\end{array}$}} \\
\hline plantio & 28 dias & 56 dias & 84 dias & & \\
\hline Maio & $3,22 \mathrm{a}^{2}$ & $8,04 \mathrm{~b}$ & $12,40 \mathrm{~b}$ & $Y=-1,23+0,16 x$ & $\mathrm{R}^{2}=99,91 \%$ \\
\hline Julho & $1,49 \mathrm{~b}$ & $3,71 \mathrm{c}$ & $6,17 \mathrm{c}$ & $Y=-0,90+0,084 x$ & $\mathrm{R}^{2}=99,92 \%$ \\
\hline Setembro & $2,88 \mathrm{a}$ & 9,79 a & $18,55 \mathrm{a}$ & $Y=-5,26+0,28 x$ & $\mathrm{R}^{2}=99,54 \%$ \\
\hline
\end{tabular}

1 Equações de regressão e coeficientes de determinação para o efeito de cada época de plantio dos tubérculos de tiririca nas épocas de amostragem.

2 Médias seguidas por letras iguais na coluna, que comparam o efeito de época plantio de tubérculo de tiririca em cada época de amostragem não diferem entre si pelo teste de Tukey a $5 \%$. 


\section{EFEITO DA PALHA DE CANA-DE-AÇÚCAR E DO TAMANHO DOS TUBÉRCULOS NA BROTAÇÃo E NO DESENVOLVIMENTO DA PARTE AÉREA DE TIRIRICA (CYPERUS ROTUNDUS L.)}

\section{Resumo}

A tiririca (Cyperus rotundus L.) é uma das plantas daninhas mais prejudiciais às culturas infestando grandes áreas das regiões tropical e subtropical, principalmente, causando perdas substanciais à produção. Ë considerada como uma das espécies daninhas mais prejudiciais à cultura da cana-de-açúcar por interferir diretamente no desenvolvimento da planta, tanto por ação competitiva em relação à fatores essenciais como água, luz e nutrientes quanto pela liberação de substâncias alelopáticas. Legislação estadual paulista estabeleceu o emprego gradativo de colheita mecanizada da cana-de-açúcar o que deixa uma camada espessa de palha, que pode afetar o desenvolvimento da tiririca. Há poucos relatos sobre o efeito do tamanho do disseminulo de espécies daninhas na germinação e no desenvolvimento de plantas. O objetivo do experimento foi verificar se a adição de palha de cana-de-açúcar poderia afetar o desenvolvimento da parte aérea da tiririca provenientes de tubérculos de tamanho pequeno $(0,22$ a $0,34 \mathrm{~g})$ e grande $(1,01$ a $1,14 \mathrm{~g})$, plantados em diferentes épocas do ano. O experimento foi instalado em casa-de-vegetação, em Campinas, SP e disposto em blocos ao acaso com quatro repetições. Tubérculos dormentes de tiririca de tamanho pequeno e grande foram plantados em maio, julho e setembro e adicionouse palha de cana-de-açúcar RB 855156, nas quantidades correspondente a 0,0, 5,0 10,0 e 15,0 t/ha. A cada 28 dias até 84 dias após o plantio, para cada época de instalação do experimento, avaliou-se o número de brotações emergidas, a altura média, a área foliar e as biomassas frescas e secas das folhas e da parte aérea total (folhas + inflorescências). Os tubérculos plantados em maio emergiram em menos tempo e mais uniformemente que os de julho e setembro. O número de brotações emergidas não foi afetado pelo tamanho de tubérculos; mas a altura, área foliar e as 
biomassa fresca e seca das folhas e parte aérea foram maiores quando originadas de tubérculos de tamanho grande. A adição de palha de cana-de-açúcar ao solo afetou mais as plantas originadas de tubérculos pequenos que de grandes. Verificou-se que, exceto para altura média, o plantio realizado em setembro proporcionou plantas com maior número de brotações, área foliar e biomassas fresca e seca de folhas e da parte aérea total. Para altura média, os melhores resultados foram observados no plantio de maio. Para todas as variáveis analisadas, o plantio dos tubérculos realizados em julho apresentaram sempre os menores valores. Aplicações de quantidades crescentes de palha de cana-de-açúcar causaram diminuição no número de brotações, área foliar e as biomassas fresca e seca das folhas e da parte aérea total. O número, a área foliar e a altura média das brotações, e as biomassas fresca e seca de folhas e da parte aérea total aumentaram linearmente em função do tempo. EFFECT OF SUGARCANE HARVEST STRAW AND TUBER SIZE ON SPROUTING
AND SHOOT GROWTH OF PURPLE NUTSEDGE (CYPERUS ROTUNDUS L.)

\section{Summary}

Purple nutsedge (Cyperus rotundus L.) is one of the most crop-damaging weeds, infesting wide areas in tropical and sub-tropical regions mainly, causing substantial yield losses. It is considered one of most important weeds in sugar cane crop, by interfering directly on the development of the plant, competing for the essential growth factors (such as water, light, and nutrients) and by liberating allelopathic substances. The São Paulo State Legislation established the gradual use of mechanical sugar cane harvest, which forms a thick layer of straw, possibly affecting the development of purple nutsedge. There are few works about the effect of tuber size of weeds species on the germination and development of cultivated plants. This experiment aimed to verify if the addition of sugar cane straw could affect the development of the aerial part of the purple nutsedge deriving from tubers of small $(0,22$ to $0,34 \mathrm{~g})$ and large $(1,01$ to $1,14 \mathrm{~g})$ sizes, planted at three different times of the year. The experiment was installed in a greenhouse at Campinas, State of o Paulo, in a randomized block with four replicates. Dormant purple nutsedge tubers of small and large sizes were planted in May, July and September, and RB 855156 sugar cane straw was added in quantities corresponding to $0,0,5,0,10,0$ and 15,0 ton/ha. Every 28 days until 84 days after 
each planting, the number of emerged sprouts, average plant height, foliar area and fresh and dry leaf and total aerial part (leaves + inflorescences) weights were evaluated. The tubers planted in May emerged sooner, and more uniformly than those planted in July and September. The number of emerged sprouts was not affected by tuber size, but plant height, foliar area, and fresh and dry leaf and aerial part weights were larger when originated from large-sized tubers. The addition of sugar cane straw to the soil affected more those plants originated from small than from large tubers. It was verified that, with the exception of average plant height, the September planting generated plants with larger number of sprouts, foliar area, fresh and dry leaf and total aerial part weights. Larger average plant height values were observed in the May planting. For all analyzed variables, the July planting presented always the smallest values. The application of growing quantities of sugar cane straw caused a decrease in the number of sprouts, foliar area, and fresh and dry leaf and total aerial part weights. The number, foliar area, and average plant height of the sprouts, and the fresh and dry leaf and total aerial part weights increased linearly as a function of time.

\subsection{Introdução}

A tiririca (Cyperus rotundus L.) é uma das plantas daninhas mais prejudiciais às culturas infestando grandes áreas das regiões tropical e subtropical, principalmente, causando perdas substanciais de produção (Jordan-Molero \& Stoller, 1978 e Victória Filho, 2000). Embora seja uma planta de estatura relativamente baixa, pode reduzir a produção de várias culturas (Keeley, 1987) por emergir e desenvolver intensamente no início do ciclo da cultura e devido também ao efeito deletério causado por sua vasta estrutura subterrânea.

Arévalo (1998) a considera como uma das espécies daninhas mais prejudiciais à cultura da cana-de-açúcar. Interfere diretamente no desenvolvimento da planta de cana-de-açúcar, tanto por ação competitiva em relação à fatores essenciais como água, luz e nutrientes quanto pela liberação de substâncias alelopáticas (Durigan, 1991). Causa ainda efeitos prejudiciais indiretos á cana-de-açúcar como, por exemplo, o aumento do custo de produção, depauperação e desvalorização da terra sendo também abrigo de pragas e doenças.

A partir de 1988 , com o decreto $n^{\circ}$. 28895, que proibiu a queima de cana-deaçúcar em um raio inferior a um quilometro de áreas consideradas de preservação ambiental e próximas a redes elétricas, rodovias e ferrovias, a indústria sucroalcooleira 
do Estado de São Paulo vem sendo pressionada a realizar a colheita sem queima prévia do canavial, utilizando máquinas. Nesse sistema chamado de cana crua ou cana verde, é deixada sobre o solo uma cobertura de palha que pode superar 20,0 t/ha (Velini \& Negrisoli, 2000). Resíduos vegetais deixados sobre o solo ocasionam mudanças nas condições químicas, físicas e biológicas do ambiente agrícola, e contribuindo para aumentar o teor de matéria orgânica; também reduzem a perda de solo por erosão e aumentam a penetração e retenção da água (Blevins et al., 1971) e facilitam o controle de plantas daninhas (Medeiros, 2001). Essas modificações no ambiente físico e químico do solo afetam a brotação e crescimento das plantas. A maior conservação da umidade do solo pode favorecer a germinação de algumas plantas daninhas pois propicia um ambiente favorável à emergência (Teasdale \& Mohler, 1993).

Há relatos que a tiririca no sistema cana crua, não é afetada quanto à sua densidade populacional mas, na presença de palha deixada por vários anos, ocorre maior enraizamento e tuberização na superficie do solo. Esse fato torna a tiririca mais sensível à estresse hídrico, principalmente na época mais seca do ano facilitando sua erradicação por ocasião da reforma do canavial (Medeiros, 2001).

Baker (1972) relatou que em circunstâncias em que ocorre variação do ambiente, é de se esperar que haja mudanças na biologia reprodutiva das plantas. Ele observou que espécies que se desenvolvem sob condições sombreadas apresentam disseminulos com maior biomassa. O mesmo ocorre quando a espécie está se desenvolvendo em ambiente que está em estádio de sucessão mais avançado. Em ambos os casos, dissemínulos com maior biomassa estão associados com maior quantidade de provisão de reservas nutritivas destinadas às plântulas, o que as torna capazes de estabelecer sua parte aérea mais rapidamente permitindo que a fotossintese inicie bem mais cedo.

Há poucos relatos sobre o efeito do tamanho do dissemínulo de espécies daninhas na germinação e no desenvolvimento de plantas cultivadas. McWilliams et al. (1968) estudaram a variação da biomassa de sementes de Amaranthus retroflexus L. na germinação e Hammerton (1974) em alguns aspectos do crescimento da tiririca.

O objetivo do experimento foi verificar se a adição de quantidades diferentes de palha de cana-de-açúcar poderia afetar a emergência e o desenvolvimento de plantas de tiririca provenientes de tubérculos de tamanho pequeno e grande, plantados em diferentes épocas do ano. 


\subsection{Material e Métodos}

Nos meses de maio, julho e setembro de 2003, no Centro Experimental do Instituto Agronômico em Campinas, SP, foram coletadas plantas de tiririca. Descartouse suas partes aéreas, bulbos basais, rizomas e raízes e utilizou-se apenas os tubérculos dormentes, túrgidos, com aspecto sadio e que não apresentassem danos fisicos. Os tubérculos foram limpos com papel toalha, separados quanto ao tamanho, grande e pequeno, acondicionados em latas de alumínio e mantidos sob refrigeração por, no máximo três dias, até o plantio. Logo após a separação dos tubérculos, foram coletadas para cada tamanho de tubérculos, ao acaso, dez amostras com dez indivíduos cada e avaliou-se suas biomassas frescas (Tabela 1, página 33).

Da mesma área de onde foram retiradas as plantas de tiririca, foi coletado solo argiloso na profundidade de $0-20 \mathrm{~cm}$. Esse foi peneirado sob crivo fino para retirada de torrões, restos de vegetais e de tubérculos de tiririca e colocado em vasos plásticos com capacidade para seis litros, com furos para percolação da solução do solo. Não foi adicionado corretivo nem fertilizante. As características químicas e físicas do solo das coletas realizadas em maio, julho e setembro são apresentadas na Tabela 2 (página 34).

O experimento foi instalado na casa-de-vegetação do Centro de Ecofisiologia e Biofísica, em Campinas, SP, em 27/05, 03/07 e 08/09/2003 e disposto em blocos ao acaso, com quatro repetições. Os tratamentos consistiram na combinação entre o tamanho de tubérculo de tiririca, pequeno e grande, e quantidades de palhas que foram adicionadas à superficie do solo nas quantidades equivalentes a 0,0, 5,0 10,0 e 15,0 t/ha. A palha de cana-de-açúcar era do cultivar RB 855156 e foi coletada na Usina Costa Pinto, em Piracicaba, SP. Para cada tratamento foram plantados, em cada vaso, nas datas acima descritas, seis tubérculos de tiririca na profundidade de 0,03 $\mathrm{m}$.

Em cada época de plantio de tubérculos, em intervalos regulares de 28 dias até 84 dias, retirou-se a palha, contou-se o número de brotações e de inflorescências e mediu-se a altura de cada uma das brotações. A seguir, a parte aérea foi cortada rente ao solo, separada em folhas e inflorescências, lavadas em água corrente, secas em papel absorvente e avaliaram-se suas biomassas frescas. As folhas foram mantidas sob refrigeração, por no máximo duas horas até a determinação da área foliar. As estruturas da parte aérea, após secagem em estufa sob ventilação forçada a $65-70^{\circ} \mathrm{C}$, até atingir massa constante, foram avaliadas quanto às suas biomassas secas.

As variáveis foram submetidas à análise de variância usando o teste $\mathrm{F}$ e quando 
o efeito do tamanho dos dissemínulos foi significativo, as médias foram comparadas pelo teste de Tukey. Para os efeitos de época de avaliação e de instalação, e da quantidade de palhada foi usado ajuste empregando-se funções matemáticas. Analisaram-se também as biomassas fresca e seca da parte aérea total (folhas + inflorescências).

\subsection{Resultados e Discussão}

Houve diferença no número de dias para o inicio da emergência das plântulas de tiririca em função da época de plantio dos dissemínulos (dados não apresentados). Os dissemínulos do plantio de maio emergiram em menos tempo e mais uniformemente que os de setembro e julho. A emergência de plantas de tiririca cujos disseminulos foram plantados em maio iniciou-se seis dias após o plantio e não houve diferença entre plantas originadas de tubérculos pequenos e grandes e nem sob diferentes quantidades de palha. Stoller et al. (1972) também não observaram diferença na porcentagem de germinação entre tubérculos de Cyperus esculentus L. que variavam em tamanho e biomassa mas verificaram influência destes fatores no vigor das plântulas. Smith \& Camper Junior (1975) e Cazetta et al. (1995) observaram que para as culturas de soja e feijão, respectivamente, o tamanho das sementes teve pouco ou nenhum efeito na germinação e no estabelecimento inicial da planta.

No plantio de julho, a emergência iniciou-se onze dias após o plantio somente nos tratamentos sem palha e, nos outros, apenas quinze dias após. A emergência no plantio realizado em setembro iniciou-se aos nove dias no tratamento sem palha e em todos os outros, após catorze dias do plantio. Hauser (1962a) observou que em tubérculos de tiririca plantados na primavera, a maioria apresentava brotação dos sete aos dez dias. Por outro lado, William (1974) no Brasil, verificou que a emergência de folhas ocorria de quatro a dez dias em solo descoberto.

O menor número de dias para emissão de brotações no plantio realizado no mês de maio, parece ser devido às maiores temperaturas médias das máximas verificadas tanto no ar como no solo descoberto ou coberto com 10,0 e 15,0 t/ ha de palha (Tabela 14), quando em comparação com os dados dos plantios de julho e setembro. Shamsi et al. (1978) e Holt \& Orcutt (1996) determinaram o limiar térmico para a tiririca nas condições americanas. Eles observaram que os limites superior e inferior são, respectivamente, 40 e $10^{\circ} \mathrm{C}$. Miles et al. (1996) constataram que a brotação da tiririca é beneficiada por temperaturas alternadas, sendo que sob 
condições de $25 / 35^{\circ} \mathrm{C}$, a brotação era de $100 \%$ e que em temperaturas constantes de 25,30 e $35^{\circ} \mathrm{C}$, a brotação variou de 32 a 89\%. Jordan-Molero \& Stoller (1978) relataram que o crescimento e o desenvolvimento da tiririca é bastante influenciado pelo fotoperíodo e pela intensidade luminosa o que pode explicar o maior número de dias necessários para emissão das brotações no plantio realizado em julho. Relatou que o aumento no número de dias para que ocorra germinação pode influenciar o subseqüente estabelecimento da planta (Weis, 1982).

Tabela 14. Temperatura média das máximas e das mínimas do ar, do solo nu e do solo coberto com 10,0 e 20,0 t/ ha de palha no período do plantio dos tubérculo até o aparecimento da primeira brotação e do período de plantio até a emergência de, pelo menos, uma brotação em cada vaso

\begin{tabular}{|c|c|c|c|c|c|c|}
\hline \multicolumn{7}{|c|}{ Temperaturas médias das máximas $\left({ }^{\circ} \mathrm{C}\right)$} \\
\hline & \multicolumn{3}{|c|}{ Primeira emergência } & \multicolumn{3}{|c|}{ Emergência em todos os vasos } \\
\hline & Maio $^{1}$ & Julho & Setembro & Maio $^{1}$ & Julho & Setembro \\
\hline $\mathrm{Ar}$ & - & 30,8 & 30,5 & - & 31,2 & 33,3 \\
\hline Solo nu & - & 21,6 & 22,9 & - & 22,0 & 24,0 \\
\hline Palha $10,0 \mathrm{t} / \mathrm{ha}$ & - & 25,3 & 27,8 & - & 25,6 & 29,8 \\
\hline Palha 20,0 t/ha & - & 23,0 & 28,4 & - & 23,9 & 30,7 \\
\hline \multicolumn{7}{|c|}{ Temperaturas médias das mínimas $\left({ }^{\circ} \mathrm{C}\right)$} \\
\hline & \multicolumn{3}{|c|}{ Primeira emergência } & \multicolumn{3}{|c|}{ Emergência em todos os vasos } \\
\hline & Maio $^{1}$ & Julho & Setembro & Maio $^{1}$ & Julho & Setembro \\
\hline $\mathrm{Ar}$ & - & 12,8 & 16,8 & - & 12,9 & 17,0 \\
\hline Solo nu & - & 12,5 & 14,9 & - & 12,6 & 14,5 \\
\hline Palha $10,0 \mathrm{t} / \mathrm{ha}$ & - & 14,8 & 17,0 & - & 14,9 & 17,3 \\
\hline Palha $20,0 \mathrm{t} / \mathrm{ha}$ & - & 14,8 & 17,5 & - & 15,1 & 18,1 \\
\hline
\end{tabular}

1 Dados não anotados.

Em alguns tratamentos, foi observado que ocorria produção de brotação a partir do bulbo basal, que não era capaz de alcançar a superficie do solo. O mesmo foi observado por Hammerton (1974) em condição de campo na Jamaica. Segundo esse autor não há uma explicação de sua causa ou função embora seja uma desvantagem para a planta. Não houve diferença significativa entre tratamentos para número e biomassas fresca e seca de inflorescências (dados não apresentados). Foi observado que plantas originadas de tubérculos grandes apresentaram indivíduos com maior vantagem competitiva. O tamanho maior dos tubérculos influenciou positivamente a área foliar das brotações em relação ao pequeno (Tabela 15). O mesmo foi observado 
nas diferentes épocas de plantio para altura média das brotações (Tabela 15) e para biomassas fresca e seca de folhas e da parte aérea total (Tabela 16). Black (1958) também observou que sementes maiores de trevo subterrâneo produziam plântulas com maior altura. Estas podiam competir com vantagem com aquelas provenientes de sementes pequenas principalmente se os dois tipos de plântulas crescessem no mesmo ambiente. Cazetta et al. (1995) verificaram que, para as condições do Brasil, o tamanho das sementes de feijão influenciou direta e significativamente a biomassa seca das plântulas.

Tabela 15. Efeito do tamanho dos tubérculos de tiririca na área foliar e da interação entre tamanho e época de plantio de dissemínulos para altura média das brotações

\begin{tabular}{|c|c|c|c|c|}
\hline Tamanho & Área & \multicolumn{3}{|c|}{ Altura média das brotações } \\
\hline dos & foliar & Maio & Julho & Setembro \\
\hline tubérculos & $\mathrm{cm}^{2}$ & & $\mathrm{~cm}$ & \\
\hline Pequeno & $200,76 \mathrm{~B}^{1}$ & $23,10 \mathrm{aB}^{2}$ & $17,66 \mathrm{bB}$ & $19,00 \mathrm{bB}$ \\
\hline Grande & $261,20 \mathrm{~A}$ & $24,36 \mathrm{aA}$ & $21,32 \mathrm{bA}$ & $20,33 \mathrm{bA}$ \\
\hline
\end{tabular}

${ }^{1}$ Médias seguidas pela mesma letra maiúscula, na coluna, não diferem entre si pelo teste de Tukey a $5 \%$.

2 Médias seguidas pela mesma letra minúscula, na linha, que comparam o efeito da época de plantio dos tubérculos de tiririca para cada tamanho de disseminulo e, pela mesma letra maiúscula, na coluna, que comparam o tamanho dos tubérculos para cada época de plantio dos disseminulos, não diferem entre si pelo teste de Tukey a $5 \%$.

Lópes-Castañeda et al. (1996) relataram que plantas originadas de dissemínulos com embriões de tamanho grande, possuem maior vigor, porque quando a embebição é iniciada há mais células se expandindo e as zonas meristemáticas são maiores. Além disso, apresentam maiores quantidades de carboidrato e de nitrogênio o que estimula o crescimento e o desenvolvimento inicial das plântulas. No presente experimento, não foi observada diferença de velocidade de emergência em função do tamanho dos dissemínulos pequenos e grandes, mas a maior quantidade de reserva dos tubérculos maiores favoreceu o crescimento das plantas.

A altura média das brotações foi maior quando os dissemínulos foram plantados em maio tanto nas plantas originadas de tubérculos pequenos como grandes (Tabela 15). Entretanto, as biomassas fresca e seca da parte aérea total e seca das folhas, para ambos os tamanhos de disseminulos, foram maiores quando plantados em setembro (Tabela 16). O mesmo foi observado para biomassa fresca de folhas das 
plantas originadas de tubérculos pequenos. Para plantas originadas de tubérculos grandes não houve diferença de biomassa fresca de folhas nos plantios de maio ou em setembro. Para todas as variáveis, menores valores foram obtidos quando os tubérculos foram plantados em julho (Tabelas 15 e 16).

Tabela 16. Efeito da interação entre tamanho de tubérculos de tiririca e época de plantio destes nas biomassas frescas e secas de folhas e da parte aérea total

\begin{tabular}{|c|c|c|c|c|c|}
\hline Época de & \multicolumn{2}{|c|}{ Biomassa fresca de folhas (g) } & Época de & \multicolumn{2}{|c|}{ Biomassa fresca de p. aérea total $(\mathrm{g})$} \\
\hline $\begin{array}{l}\text { plantio de } \\
\text { tubérculos }\end{array}$ & Pequeno & Grande & $\begin{array}{l}\text { plantio de } \\
\text { tubérculos }\end{array}$ & Pequeno & Grande \\
\hline Maio & $10,25 \mathrm{bB}^{1}$ & 14,18 aA & Maio & $10,67 \mathrm{bB}$ & $15,73 \mathrm{bA}$ \\
\hline Julho & $5,72 \mathrm{cB}$ & $8,18 \mathrm{bA}$ & Julho & $5,74 \mathrm{cB}$ & $8,32 \mathrm{cA}$ \\
\hline Setembro & $12,99 \mathrm{aB}$ & $14,60 \mathrm{aA}$ & Setembro & $16,58 \mathrm{aA}$ & $19,32 \mathrm{aA}$ \\
\hline Época de & \multicolumn{2}{|c|}{ Biomassa seca de folhas (g) } & Época de & \multicolumn{2}{|c|}{ Biomassa seca de p. aérea total $(\mathrm{g})$} \\
\hline $\begin{array}{l}\text { plantio de } \\
\text { tubérculos }\end{array}$ & Pequeno & Grande & $\begin{array}{l}\text { plantio de } \\
\text { tubérculos }\end{array}$ & Pequeno & Grande \\
\hline Maio & $1,78 \mathrm{~b} 11 \mathrm{~B}$ & $2,44 \mathrm{bA}$ & Maio & $1,88 \mathrm{bB}$ & $2,77 \mathrm{bA}$ \\
\hline Julho & $0,60 \mathrm{cB}$ & $1,02 \mathrm{cA}$ & Julho & $0,88 \mathrm{cB}$ & $1,54 \mathrm{cA}$ \\
\hline Setembro & $2,64 \mathrm{aB}$ & $2,87 \mathrm{aA}$ & Setembro & $3,38 \mathrm{aB}$ & 3,87 aA \\
\hline
\end{tabular}

${ }^{1}$ Médias seguidas pela mesma letra minúscula, na coluna, que comparam o efeito de cada época de plantio dos tubérculos dentro de tamanho de tubérculos de tiririca e pela mesma letra maiúscula, na linha, que comparam o efeito do tamanho dos tubérculos dentro de cada época destes não diferem entre si pelo teste de Tukey a $5 \%$.

Não foi observada interação significativa entre tamanho de tubérculos e época de avaliação para número, altura média e área foliar das brotações e para biomassas fresca e seca das folhas e fresca da parte aérea total (dados não apresentados). Entretanto, para biomassa seca da parte aérea total foi observado que tanto para plantas provenientes de tubérculos pequenos como de grandes, houve aumento linear em função do tempo (Figura 8). Jordan-Molero \& Stoller (1978) também verificaram que o crescimento da tiririca medido pelo acúmulo de biomassa seca aumentou linearmente em função do tempo. A colocação de palha sobre o solo simula que os propágulos foram plantados em maior profundidade. Ogg Junior \& Dawson (1984) relataram que a emergência sob condição de solo coberto é dependente da espécie. Eles observaram que a emergência de algumas plantas daninhas de folhas largas é estimulada enquanto que outras não é afetada, e para uma poácea foi reduzida. $\mathrm{Na}$ condição do presente experimento não foi constatada interação significativa entre tamanho de tubérculos e quantidade de palha adicionada para número, altura média, 
área foliar das brotações e biomassa seca das folhas (dados não apresentados). Como observado nesse experimento, Black (1956) também não verificou efeito do tamanho das sementes de trevo subterrâneo quando plantado mais profundamente sobre o número de folhas, área foliar e biomassa seca.

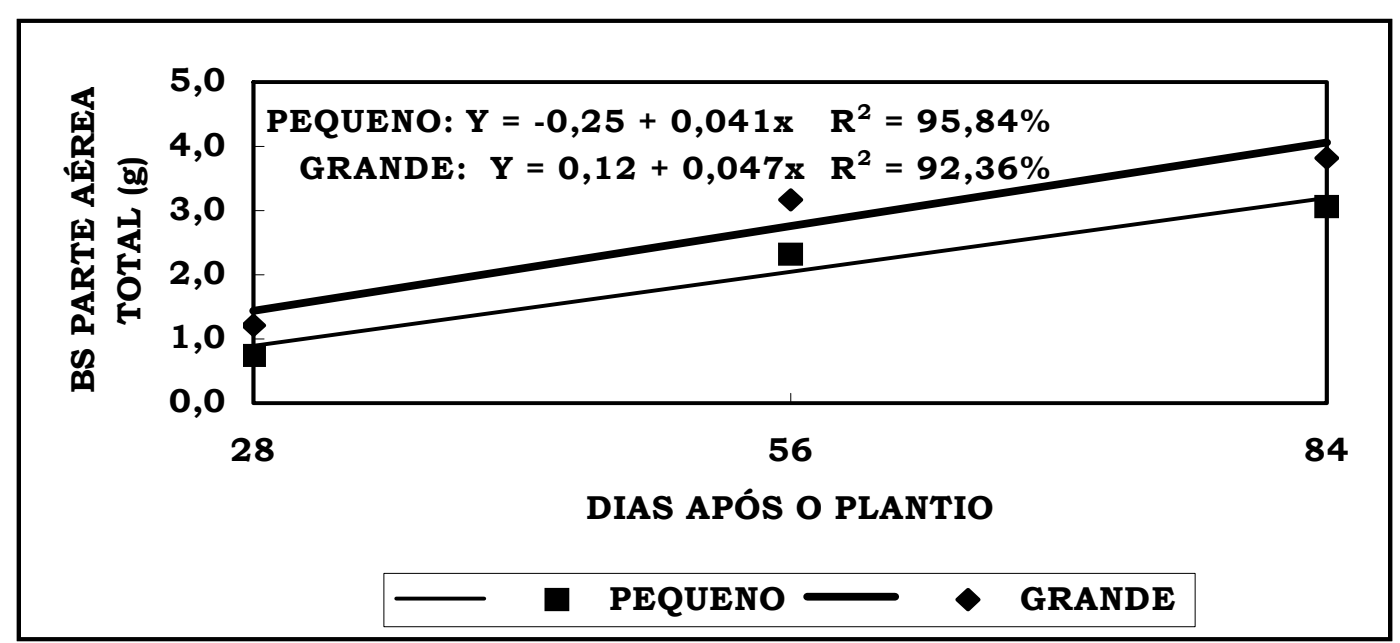

Figura 8 - Efeito da interação entre tamanho de tubérculos de tiririca e época de amostragem ( dias após o plantio dos tubérculos) na biomassa seca (BS) da parte aérea total

De modo geral, para quaisquer das quantidades de palha adicionadas ao solo, verificou-se que plantas de tiririca provenientes de tubérculos pequenos foram as mais afetadas pelo aumento da quantidade de palha depositada sobre o solo (Tabela 17). Costa et al. (1973) observaram o mesmo para plantas de soja oriundas de sementes pequenas e que haviam sido semeadas mais profundamente. Plantas originadas de tubérculos grandes produziram maiores biomassas fresca das folhas e fresca e seca da parte aérea total com quaisquer das quantidades de palha adicionadas. Gross (1984) avaliando espécies distintas com tamanhos de semente diferentes, observou que em área onde o solo estava coberto com restos vegetais, as plantas originadas de sementes pequenas tiveram suas emergências reduzidas e as de dissemínulos médios e grandes, não. Também observou que havia correlação positiva entre as biomassas da cobertura vegetal e das sementes.

A adição de palha reduziu a biomassa fresca das folhas provenientes de tubérculos pequenos e grandes, atingindo valores mínimos com a adição de 9,2 e 8,7 
t/ha (Tabela 17). A biomassa fresca da parte aérea total proveniente de tubérculos pequenos, atingiu o menor valor com a adição de 11,0 t/ha e a de tubérculos grandes com 10,1 t/ha. Por outro lado, a biomassa seca da parte aérea total de plantas provenientes de dissemínulos pequenos e grandes atingiram seus valores mínimos com 5,0 e 10,4 t/ha, respectivamente. Teasdale (1996) relatou que a biomassa de plantas daninhas é reduzida com o aumento da quantidade de resíduo vegetal deixado sobre o solo. Concluiu que a quantidade de biomassa é mais importante que o tipo de resíduo.

Tabela 17. Efeito da interação entre tamanho dos tubérculos de tiririca e quantidade de palha adicionada ao solo nas biomassas fresca de folhas e fresca e seca e da parte aérea total

\begin{tabular}{|c|c|c|c|c|c|c|}
\hline \multirow{3}{*}{$\begin{array}{l}\text { Tamanho } \\
\text { dos } \\
\text { tubérculos }\end{array}$} & \multicolumn{6}{|c|}{ Biomassa fresca de folhas (g) } \\
\hline & \multicolumn{4}{|c|}{ Quantidade de palha } & \multirow{2}{*}{\multicolumn{2}{|c|}{$\begin{array}{l}\text { Equações de ajuste e } \\
\text { coeficiente de determinação }{ }^{1}\end{array}$}} \\
\hline & $0,0 \mathrm{t} / \mathrm{ha}$ & $5,0 \mathrm{t} / \mathrm{ha}$ & $10,0 \mathrm{t} / \mathrm{ha}$ & $15,0 \mathrm{t} / \mathrm{ha}$ & & \\
\hline Pequeno & $11,68 b^{2}$ & $10,45 \mathrm{a}$ & $8,81 \mathrm{~b}$ & $9,49 \mathrm{~b}$ & $Y=11,54-0,68 x+0,037 x^{2}$ & $\mathrm{R}^{2}=93,95 \%$ \\
\hline Grande & $15,64 \mathrm{a}$ & $8,65 \mathrm{~b}$ & $11,17 \mathrm{a}$ & $12,02 \mathrm{a}$ & $Y=15,35-1,11 x+0,064 x^{2}$ & $\mathrm{R}^{2}=89,54 \%$ \\
\hline Tamanho & \multicolumn{6}{|c|}{ Biomassa fresca da parte aérea total (g) } \\
\hline dos & \multicolumn{4}{|c|}{ Quantidade de palha } & \multirow{2}{*}{\multicolumn{2}{|c|}{$\begin{array}{c}\text { Equações de ajuste e } \\
\text { coeficiente de determinação }\end{array}$}} \\
\hline tubérculos & $0,0 \mathrm{t} / \mathrm{ha}$ & $5,0 \mathrm{t} / \mathrm{ha}$ & $10,0 t / h a$ & $15,0 t / h a$ & & \\
\hline Pequeno & $14,80 \mathrm{~b}$ & $9,81 \mathrm{~b}$ & $9,51 \mathrm{~b}$ & $9,85 \mathrm{~b}$ & $Y=14,60-1,10 x+0,05 x^{2}$ & $\mathrm{R}^{2}=95,82 \%$ \\
\hline Grande & 20,56 a & 11,98 a & $12,48 \mathrm{a}$ & 12,79 a & $Y=20,10-1,79 x+0,089 x^{2}$ & $R^{2}=91,39 \%$ \\
\hline Tamanho & \multicolumn{6}{|c|}{ Biomassa seca da parte aérea total (g) } \\
\hline dos & \multicolumn{4}{|c|}{ Quantidade de palha } & \multirow{2}{*}{\multicolumn{2}{|c|}{$\begin{array}{c}\text { Equações de ajuste e } \\
\text { coeficiente de determinação }\end{array}$}} \\
\hline tubérculos & $0,0 \mathrm{t} / \mathrm{ha}$ & $5,0 \mathrm{t} / \mathrm{ha}$ & $10,0 t / h a$ & $15,0 t /$ ha & & \\
\hline Pequeno & $2,71 \mathrm{~b}$ & $1,84 \mathrm{~b}$ & $1,74 \mathrm{~b}$ & $1,89 \mathrm{~b}$ & $Y=2,68-0,20 x+0,020 x^{2}$ & $\mathrm{R}^{2}=97,89 \%$ \\
\hline Grande & 3,69 a & $2,34 \mathrm{a}$ & $2,40 \mathrm{a}$ & $2,49 \mathrm{a}$ & $Y=3,62-0,29 x+0,014 x^{2}$ & $\mathrm{R}^{2}=92,40 \%$ \\
\hline
\end{tabular}

${ }^{1}$ Equações de regressão e coeficientes de determinação para o efeito da quantidade de palha adicionada para cada tamanho os tubérculos de tiririca.

2 Médias seguidas pela mesma letra minúscula, na coluna, que comparam o efeito do tamanho dos tubérculos de tiririca para cada quantidade de palha adicionada ao solo, não diferem entre si pelo teste de Tukey a $5 \%$.

Pelos dados da Tabela 17, verificou-se ainda que tanto para tubérculos pequenos como para grandes, no tratamento sem palha, as biomassas fresca de folhas, e fresca e seca da parte aérea total foram maiores quando foi adicionado palha. Salton \& Mielnickzuk (1995) observaram que solos sem cobertura vegetal apresentaram, geralmente, maior amplitude térmica diária do que os protegidos com algum resíduo vegetal. Theisen et al. (2000) verificaram que em solo sem cobertura vegetal, sementes de gramíneas como a de Brachiaria plantaginea situadas mais próximas da superfície, 
sofreram efeito térmico mais acentuado e passaram rapidamente de dormentes a quiescentes ficando assim aptas a germinar. Para os mesmos autores em solo onde há cobertura, ocorre redução da quantidade e da qualidade da luz que atinge os propágulos, havendo redução da brotação.

Morton \& Buchele (1960) observaram que é necessário maior quantidade de energia para as plântulas emergirem quando os propágulos estão localizados a maior profundidade. Entretanto, Mohler \& Galford (1997) verificaram que em solo com cobertura vegetal em que deveria ser esperado que mais plântulas emergissem de profundidade maiores, pois há maior porosidade e menor compactação devido à ação de raízes e organismos e portanto é necessário menos esforço mecânico para alcançar a superficie, isso não ocorria. Como há menos contato entre o solo e a semente foi observado menor número de plântulas.

Em relação ao número de brotações, de modo geral, verificou-se que este foi maior quando os dissemínulos foram plantados em setembro e menor em julho, para quaisquer das quantidades de palha adicionadas ao solo (Tabela 18). Entretanto, nas mesmas condições, a altura média das brotações foi maior em maio (Tabela 18). William (1978) observou que a altura da planta de tiririca era função do fotoperíodo; obteve plantas menores quando o fotoperíodo era maior.

No plantio de dissemínulos realizado em setembro, foram observadas maiores áreas foliares no tratamento sem palha ou com a adição de 10,0 t/ha de palha (Tabela 18). Com a adição de 5,0 e 15,0 t/ha, não houve diferença quando o plantio foi realizado em maio e setembro.

Para a biomassa fresca de folhas, houve diferença entre os plantios realizados em maio e setembro apenas no tratamento sem palha (Tabela 19). Quando foi adicionada palha, não houve diferença na biomassa fresca de folhas entre maio e setembro. A biomassa fresca da parte aérea total foi maior no plantio realizado em setembro até a adição de 10,0 t/ha de palha. Com 15,0 t/ha, não houve diferença na biomassa fresca da parte aérea total quando o plantio foi realizado em maio e setembro. As biomassas secas de folhas e da parte aérea total, para quaisquer quantidades de palha adicionada, foram sempre maiores no plantio realizado em setembro. William (1978) verificou que a biomassa seca de folhas e da parte aérea total geralmente, aumentava em épocas do ano em que o fotoperiodo era maior, como observado nesse experimento. Verificou também que plantas de tiririca com três meses de idade sob fotoperíodo de oito horas, produziram menor biomassa seca total do que quando mantidas sob doze ou dezesseis horas de luz. A área foliar das brotações e 
biomassas frescas e secas de folhas e parte aérea total, para qualquer quantidade de palha adicionada, foram sempre menores no plantio realizado em julho (Tabelas $18 \mathrm{e}$ 19).

Tabela 18. Efeito da interação entre época de plantio de tubérculos de tiririca e quantidade de palha adicionada ao solo no número, altura média e área foliar de brotações

\begin{tabular}{|c|c|c|c|c|c|c|}
\hline \multirow{3}{*}{$\begin{array}{l}\text { Época de } \\
\text { plantio } \\
\text { tubérculos }\end{array}$} & \multicolumn{6}{|c|}{ Número de brotações ${ }^{1}$} \\
\hline & \multicolumn{4}{|c|}{ Quantidade de palha } & \multirow{2}{*}{\multicolumn{2}{|c|}{$\begin{array}{l}\text { Equações de ajustes e } \\
\text { coeficientes de determinação² }\end{array}$}} \\
\hline & $0,0 \mathrm{t} / \mathrm{ha}$ & $5,0 \mathrm{t} / \mathrm{ha}$ & $10,0 t /$ ha & $15,0 t / h a$ & & \\
\hline Maio & $12,11 \mathrm{~b}^{3}$ & $9,59 \mathrm{~b}$ & $9,28 \mathrm{~b}$ & $10,20 \mathrm{~b}$ & $Y=3,62-0,09 x+0,0051 x^{2}$ & $\mathrm{R}^{2}=99,13 \%$ \\
\hline Julho & $7,28 \mathrm{~b}$ & $6,76 \mathrm{c}$ & $6,42 \mathrm{c}$ & $7,13 \mathrm{c}$ & \multicolumn{2}{|l|}{ Não significativo } \\
\hline Setembro & 23,05 a & 18,76 a & 16,86 a & 15,36 a & $Y=4,82-0,056 x$ & $\mathrm{R}^{2}=94,87 \%$ \\
\hline Época de & \multicolumn{6}{|c|}{ Altura média das brotações $(\mathrm{cm})$} \\
\hline plantio & \multicolumn{4}{|c|}{ Quantidade de palha } & \multirow{2}{*}{\multicolumn{2}{|c|}{$\begin{array}{c}\text { Equações de ajustes e } \\
\text { coeficientes de determinação }\end{array}$}} \\
\hline tubérculos & $0,0 \mathrm{t} / \mathrm{ha}$ & $5,0 \mathrm{t} / \mathrm{ha}$ & $10,0 t / h a$ & $15,0 t / h a$ & & \\
\hline Maio & $22,73 \mathrm{a}$ & 23,17 a & $23,27 \mathrm{a}$ & 25,75 a & $Y=22,87+0,12 x$ & $\mathrm{R}^{2}=93,45 \%$ \\
\hline Julho & $17,25 \mathrm{c}$ & $18,18 \mathrm{~b}$ & $20,55 \mathrm{~b}$ & $22,00 \mathrm{~b}$ & $Y=16,99+0,33 x$ & $\mathrm{R}^{2}=97,56 \%$ \\
\hline Setembro & $20,90 \mathrm{~b}$ & $18,28 \mathrm{~b}$ & $19,66 \mathrm{~b}$ & $19,81 \mathrm{c}$ & $Y=20,64-0,45 x+0,027 x^{2}$ & $\mathrm{R}^{2}=60,44 \%$ \\
\hline Época de & \multicolumn{6}{|c|}{ Área foliar $\left(\mathrm{cm}^{2}\right)$} \\
\hline plantio & \multicolumn{4}{|c|}{ Quantidade de palha } & \multirow{2}{*}{\multicolumn{2}{|c|}{$\begin{array}{c}\text { Equações de ajustes e } \\
\text { coeficientes de determinação }\end{array}$}} \\
\hline tubérculos & $0,0 \mathrm{t} / \mathrm{ha}$ & $5,0 \mathrm{t} / \mathrm{ha}$ & $10,0 t / h a$ & $15,0 t /$ ha & & \\
\hline Maio & $298,75 \mathrm{~b}$ & 238,29 a & $262,92 \mathrm{~b}$ & $272,44 a$ & $Y=293,74-1,58 x+0,69 x^{2}$ & $\mathrm{R}^{2}=73,20 \%$ \\
\hline Julho & $101,79 \mathrm{c}$ & $88,43 \mathrm{~b}$ & $105,43 \mathrm{c}$ & $130,09 \mathrm{~b}$ & $Y=100,65-3,67 x+0,38 x^{2}$ & $\mathrm{R}^{2}=97,16 \%$ \\
\hline Setembro & 405,88 a & 269,63 a & 329,70 a & 268,39 a & $Y=389,99-18,29 x+0,75 x^{2}$ & $\mathrm{R}^{2}=60,13 \%$ \\
\hline \multicolumn{7}{|c|}{$\begin{array}{l}1 \text { Os dados foram transformados em raiz de } \mathrm{x}+1 \text { para análise estatística mas são apresentados } \\
\text { os dados originais. } \\
2 \text { Equações de regressão e coeficientes de determinação para o efeito da quantidade de palha } \\
\text { adicionada dentro de cada época de plantio do disseminulo de tiririca } \\
3 \text { Médias seguidas pela mesma letra minúscula, na coluna, que comparam o efeito da época de } \\
\text { plantio dos tubérculos de tiririca dentro de cada quantidade de palha adicionada ao solo, não } \\
\text { diferem entre si pelo teste de Tukey a } 5 \% \text {. }\end{array}$} \\
\hline
\end{tabular}

Quanto ao efeito da quantidade de palha adicionada em cada época de plantio, verificou-se que em maio, o número de brotações diminuiu até a adição de 9,0 t/ha (Tabela 18). Em julho, não foi observada diferença quanto ao número de brotações em função da palha adicionada. Em setembro, com a adição crescente de palha, foi observada uma redução linear no número de brotações. Medeiros (2001) relatou que a emergência das plantas daninhas pode ser reduzida pelos resíduos vegetais deixados 
sobre o solo por diminuir a alternância de temperatura, impedir que as sementes recebam luz solar, podendo ainda dificultar a elongação do hipocótilo. Os dados de temperatura do ar, solo sem e com 10,0 e 15,0 t/ha de palha mostram a menor amplitude térmica no tratamento com essa cobertura vegetal.

Tabela 19. Efeito da interação entre quantidade de palha adicionada ao solo e época de plantio dos tubérculos de tiririca nas biomassas frescas e secas de folhas e da parte aérea total

\begin{tabular}{|c|c|c|c|c|c|c|}
\hline \multirow{3}{*}{$\begin{array}{l}\text { Época de } \\
\text { plantio } \\
\text { tubérculo }\end{array}$} & \multicolumn{6}{|c|}{ Biomassa fresca de folhas (g) } \\
\hline & \multicolumn{4}{|c|}{ Quantidade de palha } & \multirow{2}{*}{\multicolumn{2}{|c|}{$\begin{array}{l}\text { Equações de ajuste e } \\
\text { coeficiente de determinação }{ }^{1}\end{array}$}} \\
\hline & $0,0 \mathrm{t} / \mathrm{ha}$ & $5,0 \mathrm{t} / \mathrm{ha}$ & $10,0 t / h a$ & $15,0 t / h a$ & & \\
\hline Maio & $14,57 b^{2}$ & $10,71 \mathrm{a}$ & $11,20 \mathrm{a}$ & $12,39 \mathrm{a}$ & $Y=14,38-0,88 x+0,051 x^{2}$ & $\mathrm{R}^{2}=92,48 \%$ \\
\hline Julho & $65 \mathrm{c}$ & $6,26 \mathrm{~b}$ & $7,07 \mathrm{~b}$ & $7,83 \mathrm{~b}$ & $Y=26,30+0,087 x$ & $\mathrm{R}^{2}=69,46 \%$ \\
\hline Setembro & 19,76 a & $11,69 \mathrm{a}$ & $11,69 \mathrm{a}$ & $12,04 \mathrm{a}$ & $Y=19,37-1,73 x+0,084 x^{2}$ & $\mathrm{R}^{2}=93,70 \%$ \\
\hline Época de & \multicolumn{6}{|c|}{ Biomassa fresca de parte aérea (g) } \\
\hline plantio & \multicolumn{4}{|c|}{ Quantidade de palha } & \multirow{2}{*}{\multicolumn{2}{|c|}{$\begin{array}{c}\text { Equações de ajuste e } \\
\text { coeficiente de determinação }\end{array}$}} \\
\hline tubérculo & $0,0 \mathrm{t} / \mathrm{ha}$ & $5,0 \mathrm{t} / \mathrm{ha}$ & $10,0 t / h a$ & $15,0 t / h a$ & & \\
\hline Maio & $17,19 \mathrm{~b}$ & $11,19 \mathrm{~b}$ & $11,69 \mathrm{~b}$ & $12,72 \mathrm{a}$ & $Y=16,89-1,31 x+0,07 x^{2}$ & $\mathrm{R}^{2}=92,07 \%$ \\
\hline Julho & $6,74 \mathrm{c}$ & $6,32 \mathrm{c}$ & $7,21 \mathrm{c}$ & $7,83 \mathrm{~b}$ & \multicolumn{2}{|c|}{ Não significativo } \\
\hline Setembro & $29,11 \mathrm{a}$ & 15,18 a & $14,08 \mathrm{a}$ & $13,41 \mathrm{a}$ & $Y=28,49-2,95 x+0,13 x^{2}$ & $\mathrm{R}^{2}=\mathrm{c}$ \\
\hline Época de & \multicolumn{6}{|c|}{ Biomassa seca de folhas (g) } \\
\hline plantio & \multicolumn{4}{|c|}{ Quantidade de palha } & \multirow{2}{*}{\multicolumn{2}{|c|}{$\begin{array}{l}\text { Equações de ajuste e } \\
\text { coeficiente de determinação }\end{array}$}} \\
\hline tubérculo & $0,0 \mathrm{t} / \mathrm{ha}$ & $5,0 \mathrm{t} / \mathrm{ha}$ & $10,0 t / h a$ & $15,0 t / h a$ & & \\
\hline Maio & $2,28 \mathrm{~b}$ & $1,90 \mathrm{~b}$ & $1,96 \mathrm{~b}$ & $2,29 \mathrm{~b}$ & $Y=2,27-0,21 x+0,007 x^{2}$ & $\mathrm{R}^{2}=98,98 \%$ \\
\hline Julho & $0,75 \mathrm{c}$ & $0,69 \mathrm{c}$ & $0,84 \mathrm{c}$ & $0,96 \mathrm{c}$ & $Y=0,69+0,0162 x$ & $\mathrm{R}^{2}=72,39 \%$ \\
\hline Setembro & 3,65 a & $2,41 \mathrm{a}$ & $2,39 \mathrm{a}$ & $2,58 \mathrm{a}$ & $Y=3,60-0,28 x+0,014 x^{2}$ & $R^{2}=95,24 \%$ \\
\hline Época de & \multicolumn{6}{|c|}{ Biomassa seca de parte aérea total (g) } \\
\hline plantio & \multicolumn{4}{|c|}{ Quantidade de palha } & \multirow{2}{*}{\multicolumn{2}{|c|}{$\begin{array}{l}\text { Equações de ajuste e } \\
\text { coeficiente de determinação }\end{array}$}} \\
\hline tubérculo & $0,0 \mathrm{t} / \mathrm{ha}$ & $5,0 \mathrm{t} / \mathrm{ha}$ & $10,0 t /$ ha & $15,0 t / h a$ & & \\
\hline Maio & $2,82 \mathrm{~b}$ & $2,02 \mathrm{~b}$ & $2,08 \mathrm{~b}$ & $2,36 \mathrm{~b}$ & $Y=2,79-0,19 x+0,0108 x^{2}$ & $\mathrm{R}^{2}=94,77 \%$ \\
\hline Julho & $1,10 \mathrm{c}$ & $1,14 \mathrm{c}$ & $1,20 \mathrm{c}$ & $1,41 \mathrm{c}$ & $Y=1,07+0,020 x$ & $\mathrm{R}^{2}=84,27 \%$ \\
\hline Setembro & $5,67 \mathrm{a}$ & $3,11 \mathrm{a}$ & $2,92 \mathrm{a}$ & $2,79 \mathrm{a}$ & $Y=5,56-0,54 x+0,024 x^{2}$ & $\mathrm{R}^{2}=95,30 \%$ \\
\hline
\end{tabular}

1 Equações de regressão e coeficientes de determinação para o efeito da quantidade de palha adicionada dentro de cada época de plantio do dissemínulo de tiririca.

2 Médias seguidas pela mesma letra minúscula, na coluna, que comparam o efeito da época de plantio dos disseminulos de tiririca para cada quantidade de palha adicionada, não diferem entre si pelo teste de Tukey a $5 \%$. 
Em maio e julho, a altura média das brotações aumentou linearmente com a adição de palha (Tabela 18) e em setembro, até a adição de 8,3 t/ha. A área foliar seguiu uma equação do segundo grau, ocorrendo redução com a adição de palha, observando-se valores mínimos nos plantios de maio, julho e setembro com a adição de, respectivamente, 1,1, 4,8 e 12,2 t/ha.

Para o plantio realizado em maio, verificou-se que as biomassas frescas e secas de folhas e da parte aérea total diminuíram de acordo com uma equação do segundo grau, atingindo valores mínimos com 8,6, 9,4, 14,6 e 8,6 t/ ha, respectivamente (Tabela 19). Quando os dissemínulos foram plantados em julho, constatou-se que as biomassas fresca e seca das folhas e seca da parte aérea total aumentaram linearmente com a adição de quantidades crescentes de palha. No plantio realizado em setembro houve diminuição na biomassa seca da folha e da parte aérea total, atingindo valores minimos com quantidade de palha igual ou superior a 10,0 t/ha (Tabela 19).

Em relação ao efeito da quantidade de palha dentro de cada época de avaliação, verificou-se que, aos 28 e 56 dias, houve redução linear no número de brotações com o aumento da quantidade de palha (Tabela 20). Aos 84 dias, o número de brotações foi o menor com a adição de 12,1 t/ha. A altura média das brotações, aos 28 e 56 dias, aumentou linearmente com o aumento da palha adicionada. Aos 84 dias, o valor mínimo ocorreu com 5,3 t/ha; entretanto, com a adição de palha em quantidades superiores a 10,0 e 15,0 t/ha, a altura média das brotações foi superior àquela sem palha. Quanto à área foliar das brotações, verificou-se que a interação entre quantidade de palha adicionada dentro de cada época de amostragem foi significativa apenas aos 56 dias, sendo observado redução com a adição de palha até a quantidade estimada de 8,6 t/ha (Tabela 20)

O efeito da interação de época de avaliação dentro de cada quantidade de palha adicionada para número, altura média e área foliar das brotações é apresentado na Tabela 20. O número de brotações aumentou linearmente em função do tempo; o mesmo foi observado para área foliar das brotações quando foi adicionada palha. No tratamento sem palha, a área foliar aumentou até 67 dias. A altura média das brotações, devido à competição entre plantas, diminuiu linearmente com o tempo quando foi adicionada quantidade de palha igual ou superior a 5,0 t/ha. No tratamento sem palha, a menor altura média foi observada aos 70 dias. 
Tabela 20. Efeito da interação entre quantidade de palha adicionada ao solo e época de avaliação (dias após o plantio) no número, altura média e área foliar das brotações de tiririca

\begin{tabular}{|c|c|c|c|c|c|}
\hline \multirow{3}{*}{$\begin{array}{l}\text { Dias após o } \\
\text { plantio dos } \\
\text { tubérculos }\end{array}$} & \multicolumn{5}{|c|}{ Número de brotações ${ }^{1}$} \\
\hline & \multicolumn{4}{|c|}{ Quantidade de palha } & \multirow{2}{*}{$\begin{array}{c}\text { Equações de ajustes e } \\
\text { coeficientes de determinação }{ }^{2}\end{array}$} \\
\hline & $0,0 \mathrm{t} / \mathrm{ha}$ & $5,0 \mathrm{t} / \mathrm{ha}$ & $10,0 t / h a$ & $15,0 \mathrm{t} / \mathrm{ha}$ & \\
\hline 28 dias & 7,25 & 6,84 & 6,09 & 5,76 & $Y=2,88-0,019 x$ \\
\hline 56 dias & 14,88 & 10,94 & 10,71 & 11,56 & $Y=3,97-0,13 x$ \\
\hline 84 dias & 19,67 & 16,88 & 15,56 & 15,80 & $Y=4,55-0,082 x+0,0034 x^{2} R^{2}=99,97 \%$ \\
\hline$a^{3}$ & 2,13 & 2,06 & 1,98 & 1,91 & \\
\hline $\mathrm{b}$ & 0,0300 & 0,0255 & 0,0251 & 0,0268 & \\
\hline $\mathrm{c}$ & - & - & - & - & \\
\hline $\mathrm{R}^{2}(\%)$ & 96,51 & 99,77 & 99,80 & 97,80 & \\
\hline Dias após o & \multicolumn{5}{|c|}{ Altura média das brotações $(\mathrm{cm})$} \\
\hline plantio dos & \multicolumn{4}{|c|}{ Quantidade de palha } & \multirow{2}{*}{$\begin{array}{c}\text { Equações de ajustes e } \\
\text { coeficientes de determinação }\end{array}$} \\
\hline tubérculos & $0,0 \mathrm{t} / \mathrm{ha}$ & $5,0 \mathrm{t} / \mathrm{ha}$ & $10,0 \mathrm{t} / \mathrm{ha}$ & $15,0 t / h a$ & \\
\hline 28 dias & 22,32 & 22,66 & 23,05 & 23,69 & $Y=22,25+0,090 x$ \\
\hline 56 dias & 19,24 & 19,56 & 20,87 & 22,23 & $\mathrm{Y}=18,93+0,21 \mathrm{x}$ \\
\hline 84 dias & 19,32 & 17,41 & 19,56 & 21,64 & $Y=19,11-0,42 x+0,040 x^{2} \quad R^{2}=90,58 \%$ \\
\hline$a^{3}$ & 28,55 & 25,13 & 24,66 & 24,58 & \\
\hline $\mathrm{b}$ & $-0,2787$ & $-0,0938$ & 0,0625 & $-0,0367$ & \\
\hline $\mathrm{c}$ & 0,0020 & - & - & - & \\
\hline $\mathrm{R}^{2}(\%)$ & 100 & 98,90 & 98,03 & 94,39 & \\
\hline Dias após o & & & & Área fo & $\operatorname{iar}\left(\mathrm{cm}^{2}\right)$ \\
\hline plantio dos & & Quantida & e de palha & & Equações de ajustes e \\
\hline tubérculos & $0,0 \mathrm{t} / \mathrm{ha}$ & $5,0 \mathrm{t} / \mathrm{ha}$ & $10,0 \mathrm{t} / \mathrm{ha}$ & $15,0 t / h a$ & coeficientes de determinação \\
\hline 28 dias & 194,999 & 164,43 & 163,94 & 163,82 & Não significativo \\
\hline 56 dias & 314,29 & 190,83 & 228,29 & 248,96 & $Y=305,4-24,79 x+1,44 x^{2} R^{2}=80,33 \%$ \\
\hline 84 dias & 297,13 & 241,09 & 305,82 & 158,14 & Não significativo \\
\hline$a^{3}$ & $-60,75$ & 122,12 & 90,81 & 129,32 & \\
\hline $\mathrm{b}$ & 11,5707 & 1,3688 & 2,5335 & 1,6842 & \\
\hline $\mathrm{c}$ & $-0,0870$ & - & - & - & \\
\hline $\mathrm{R}^{2}(\%)$ & 100 & 96,87 & 99,71 & 82,22 & \\
\hline
\end{tabular}

1 Os dados foram transformados em raiz de $\mathrm{x}+1$ para análise estatística mas são apresentados os dados originais.

2 Equações de regressão e coeficientes de determinação para o efeito da quantidade de palha adicionada dentro de cada época de amostragem.

${ }^{3}$ Os valores de a, b e c são respectivamente o intercepto e os coeficientes linear e quadrático das equações de regressão. 
A biomassa fresca das folhas nas amostragens realizadas aos 28,56 e 84 dias, diminuiu com a adição de palha até as quantidades correspondentes a 11,1, 0,9 e 9,2 t/ha, respectivamente (Tabela 21). Aos 28 dias, a biomassa fresca da parte aérea diminuiu linearmente com a adição de quantidades crescentes de palha. Já aos 56 e 84 dias, a biomassas fresca da parte aérea diminuiu até a adição de palha correspondente a 9,9 e 10,2 t/ha. Quanto à biomassa seca das folhas, apenas a partir dos 56 dias houve resposta à adição de palha. Aos 56 e 84 dias, a biomassa seca de folhas diminuiu até a adição de 7,9 e 9,0 t/ha de palha respectivamente. A biomassa seca da parte aérea total também foi reduzida com a adição de palha, sendo observados os menores valores com 11,4, 9,5 e 10,3 t/ha, respectivamente, aos 28, 56 e 84 dias. Mohler \& Teasdale (1993) verificaram que em área com resíduo vegetal, no início da estação de crescimento, quando o resíduo ainda não teve tempo para se decompor, é observada maior emergência de plântulas. Posteriormente, a resposta ao resíduo vegetal varia muito entre espécies.

O efeito da época de avaliação em cada quantidade de palha adicionada ao solo para biomassas frescas e secas das folhas e da parte aérea total é apresentado na Tabela 21. A biomassa fresca das folhas, com a adição de 0,0,5,0 e 15,0 t/ha aumentou até 69,50 e 68 dias, respectivamente, não havendo resposta quando se adicionou 10,0 t/ha. No tratamento sem palha, foi observado que a biomassa fresca da parte aérea total aumentou até 66 dias. Com a adição de 5,0, 10,0 e 15,0 t/ha, houve aumento linear da biomassa fresca da parte aérea total em função do tempo. Para as biomassas secas das folhas e da parte aérea total tanto com a adição de palha como sem, houve aumento linear em função do tempo.

Nos plantios de dissemínulos de maio, julho e setembro, foi verificado aumento linear no número de brotações em função do tempo (Tabela 22). Para a altura média das brotações, apenas quando os dissemínulos foram plantados em maio e julho, foi observada redução linear em função do tempo. Para o plantio realizado em setembro, constatou-se redução na altura das brotações até 45 dias. A área foliar foi aumentou linearmente em função do tempo nos plantios de maio e setembro e em julho, houve aumento até 57 dias.

Aos 28, 56 e 84 dias, houve maior número de brotações e área foliar quando os disseminulos foram plantados em setembro (Tabela 22). Entretanto, a altura média das brotações foi maior aos 28 e 56 dias quando os dissemínulos foram plantados em setembro. Aos 84 dias, não houve diferença na altura média das brotações nos plantios de maio e de setembro. 
As biomassas fresca das folhas e fresca e seca da parte aérea, exceto na amostragem aos 28 dias, foram maiores no plantio realizado em setembro (Tabela 23). Aos 28 dias, as biomassa fresca das folhas dos plantios realizado em maio e julho foram estatísticamente iguais. Para a biomassa fresca da parte aérea, aos 28 dias, não houve diferença entre as três épocas de plantio e a biomassa seca da parte aérea, nos plantios de setembro e maio foram estatísticamente iguais e no de julho, inferior. William et al. (1977) observaram que plantios de tiririca realizados no meio do verão produziram mais biomassa seca que os de inverno. Atribuíram essa diferença à quantidade de radiação solar disponivel pois a tiririca é uma planta fotossintéticamente eficiente $\left(\mathrm{C}_{4}\right)$ que alcança o seu máximo crescimento durante os períodos de alta intensidade de luz e quando as temperaturas são mais elevadas. A diferença na radiação solar disponivel entre os meses de julho e setembro é função do comprimento do dias, sendo que nos meses de inverno este é mais curto.

As biomassas fresca de folhas e da parte aérea total das plantas originadas de dissemínulos plantados em maio e setembro aumentaram linearmente em função do tempo; por outro lado, naqueles plantados em julho ocorreu redução linear em função do tempo. A biomassa seca da parte aérea, para qualquer das épocas de plantio aumentou linearmente em função do tempo.

\subsection{Conclusões}

Concluiu-se que:

1) Os tubérculos plantados em maio emergiram em menos tempo e mais uniformemente que os de julho e setembro.

2) O número de brotações emergidas não foi afetado pelo tamanho de tubérculos; no entanto, a altura, área foliar e as biomassas fresca e seca das folhas e parte aérea foram maiores quando originadas de tubérculos de tamanho grande.

3) A adição de palha de cana-de-açúcar ao solo afetou mais plantas originadas de tubérculos pequenos que de grandes.

4) O plantio em setembro resultou em plantas com maior número de brotações, área foliar e biomassas fresca e seca de folhas e da parte aérea total. Para altura média, os melhores resultados foram observados no plantio de maio. Para todas as variáveis analisadas, o plantio dos tubérculos realizado em julho resultou sempre em menores valores. 
5) A adição de palha nas quantidades de 5,0 a 11,0 t/ ha reduziu a biomassa fresca e seca das folhas e da parte aérea total.

6) O número, a área foliar e a altura média das brotações assim como as biomassas frescas e secas de folhas e da parte aérea total aumentaram linearmente em função do tempo. 
Tabela 21. Efeito da interação entre época de avaliação e quantidade de palha adicionada ao solo nas biomassas fresca e secas de folhas e da parte aérea total de tiririca

\begin{tabular}{|c|c|c|c|c|c|}
\hline \multirow{3}{*}{$\begin{array}{l}\text { Dias após } \\
\text { o } \\
\text { plantio dos } \\
\text { tubérculos }\end{array}$} & \multicolumn{5}{|c|}{ Biomassa fresca das folhas (g) } \\
\hline & \multicolumn{4}{|c|}{ Quantidade de palha } & \multirow{2}{*}{$\begin{array}{c}\text { Equações de ajustes e } \\
\text { coeficientes de determinação }{ }^{1}\end{array}$} \\
\hline & $0,0 \mathrm{t} / \mathrm{ha}$ & $5,0 \mathrm{t} / \mathrm{ha}$ & $10,0 \mathrm{t} / \mathrm{ha}$ & $15,0 t /$ ha & \\
\hline 28 dias & 11,91 & 9,53 & 9,38 & 9,18 & $Y=11,80-0,49 x+0,022 x^{2} \quad R^{2}=94,64 \%$ \\
\hline 56 dias & 14,60 & 8,80 & 10,06 & 11,64 & $\mathrm{Y}=14,26-0,13 \mathrm{x}+0,074 \mathrm{x}^{2} \quad \mathrm{R}^{2}=87,92 \%$ \\
\hline 84 dias & 14,47 & 10,32 & 10,52 & 11,45 & $Y=14,28-0,94 x+0,051 x^{2} \quad R^{2}=94,06 \%$ \\
\hline$a^{2}$ & 6,41 & 12,50 & - & 4,05 & \\
\hline $\mathrm{b}$ & 0,25 & $-0,14$ & - & 0,23 & \\
\hline $\mathrm{c}$ & $-0,0018$ & 0,0014 & - & $-0,0017$ & \\
\hline $\mathrm{R}^{2}(\%)$ & 100,00 & 100,00 & - & 67,9 & \\
\hline Dias após & \multicolumn{5}{|c|}{ Biomassa fresca da parte aérea total (g) } \\
\hline $\begin{array}{l}\text { o } \\
\text { plantio dos }\end{array}$ & \multicolumn{4}{|c|}{ Quantidade de palha } & \multirow{2}{*}{$\begin{array}{c}\text { Equações de ajustes e } \\
\text { coeficientes de determinação }\end{array}$} \\
\hline tubérculos & $0,0 \mathrm{t} / \mathrm{ha}$ & $5,0 \mathrm{t} / \mathrm{ha}$ & $10,0 \mathrm{t} / \mathrm{ha}$ & $15,0 t /$ ha & \\
\hline 28 dias & 12,94 & 9,80 & 9,82 & 9,18 & $Y=12,11-0,23 x$ \\
\hline 56 dias & 20,88 & 10,72 & 11,00 & 12,36 & $Y=-20,36-2,17 x+0,11 x^{2} \quad R^{2}=91,94 \%$ \\
\hline 84 dias & 19,22 & 12,17 & 12,17 & 12,43 & $Y=18,91-1,53 x+0,075 x^{2} R^{2}=94,73 \%$ \\
\hline$a^{2}$ & $-4,61$ & 8,52 & 8,64 & 8,07 & \\
\hline $\mathrm{b}$ & 0,80 & 0,04 & 0,04 & 0,06 & \\
\hline c & $-0,0061$ & - & - & - & \\
\hline $\mathrm{R}^{2}(\%)$ & 100,00 & 98,34 & 93,30 & 76,47 & \\
\hline Dias após & \multirow{2}{*}{\multicolumn{5}{|c|}{ Biomassa seca das folhas (g) }} \\
\hline o & Quantidade de palha & & & & \multirow{2}{*}{$\begin{array}{c}\text { Equações de ajustes e } \\
\text { coeficientes de determinação }\end{array}$} \\
\hline tubérculos & $0,0 \mathrm{t} / \mathrm{ha}$ & $5,0 \mathrm{t} / \mathrm{ha}$ & $\begin{array}{l}\text { e de palha } \\
10,0 t / \text { ha }\end{array}$ & $15,0 t / h a$ & \\
\hline 28 dias & 1,04 & 0,91 & 0,90 & 0,91 & Não significativo \\
\hline 56 dias & 2,51 & 1,65 & 1,88 & 2,22 & $\mathrm{Y}=2,46-0,19 \mathrm{x}+0,012 \mathrm{x}^{2} \quad \mathrm{R}^{2}=80,33 \%$ \\
\hline 84 dias & 3,13 & 2,43 & 2,40 & 2,71 & $\mathrm{Y}=3,12-0,18 \mathrm{x}+0,010 \mathrm{x}^{2}$ \\
\hline$a^{2}$ & 0,14 & 0,14 & 0,23 & 0,15 & \\
\hline $\mathrm{b}$ & 0,037 & 0,027 & 0,027 & 0,03 & \\
\hline $\mathrm{c}$ & - & - & - & - & \\
\hline $\mathrm{R}^{2}(\%)$ & 94,70 & 99,99 & 96,86 & 93,60 & \\
\hline Dias após & \multicolumn{5}{|c|}{ Biomassa seca da parte aérea total (g) } \\
\hline $\begin{array}{l}\text { o } \\
\text { plantio dos }\end{array}$ & \multicolumn{4}{|c|}{ Quantidade de palha } & \multirow{2}{*}{$\begin{array}{c}\text { Equações de ajustes e } \\
\text { coeficientes de determinação }\end{array}$} \\
\hline tubérculos & $0,0 \mathrm{t} / \mathrm{ha}$ & $5,0 \mathrm{t} / \mathrm{ha}$ & $10,0 \mathrm{t} / \mathrm{ha}$ & $15,0 t /$ ha & \\
\hline 28 dias & 1,17 & 0,93 & 0,93 & 0,90 & $Y=1,15-0,05 x+0,0022 x^{2} \quad R^{2}=93,40 \%$ \\
\hline 56 dias & 3,95 & 2,17 & 2,32 & 2,52 & $\mathrm{Y}=3,86-0,38 \mathrm{x}+0,020 \mathrm{x}^{2} \quad \mathrm{R}^{2}=91,35 \%$ \\
\hline 84 dias & 4,48 & 3,16 & 2,95 & 3,15 & $Y=4,44-0,31 x+0,015 x^{2}$ \\
\hline$a^{2}$ & $-0,11$ & $-0,14$ & 0.04 & $-0,06$ & \\
\hline $\mathrm{b}$ & 0,059 & 0,040 & 0,04 & 0,04 & \\
\hline c & - & - & - & - & \\
\hline $\mathrm{R}^{2}(\%)$ & 86,58 & 99,58 & 95,57 & 93,88 & \\
\hline
\end{tabular}

1 Equações de regressão e coeficientes de determinação para o efeito da quantidade de palha adicionada dentro de cada época de amostragem.

2 Os valores de a, b e c são respectivamente o intercepto e os coeficientes linear e quadrático das equações de regressão. 
Tabela 22. Efeito da interação entre época de plantio dos tubérculos de tiririca e época de avaliação no número, altura média e área foliar das brotações

\begin{tabular}{|c|c|c|c|c|c|}
\hline \multirow{3}{*}{$\begin{array}{l}\text { Época de } \\
\text { plantio } \\
\text { tubérculos }\end{array}$} & \multicolumn{5}{|c|}{ Número de brotações ${ }^{1}$} \\
\hline & \multicolumn{3}{|c|}{ Dias após a instalação } & \multirow{2}{*}{\multicolumn{2}{|c|}{$\begin{array}{l}\text { Equações de ajustes e } \\
\text { coeficientes de determinação² }\end{array}$}} \\
\hline & 28 dias & 56 dias & 84 dias & & \\
\hline Maio & $5,73 \mathrm{~b}^{3}$ & $10,43 \mathrm{~b}$ & $15,77 \mathrm{~b}$ & $Y=1,8559+0,0268 x$ & $\mathrm{R}^{2}=99,92 \%$ \\
\hline Julho & $5,36 \mathrm{~b}$ & $7,49 \mathrm{c}$ & $7,95 \mathrm{c}$ & $Y=2,3410+0,0084 x$ & $\mathrm{R}^{2}=86,92 \%$ \\
\hline Setembro & 8,52 a & $19,34 \mathrm{a}$ & $30,60 \mathrm{a}$ & $Y=1,8687+0,0453 x$ & $\mathrm{R}^{2}=99,50 \%$ \\
\hline Época de & \multicolumn{5}{|c|}{ Altura média das brotações $(\mathrm{cm})$} \\
\hline plantio & \multicolumn{3}{|c|}{ Dias após a instalação } & \multicolumn{2}{|c|}{ Equações de ajustes e } \\
\hline tubérculos & 28 dias & 56 dias & 84 dias & \\
\hline Maio & $26,53 \mathrm{a}$ & 23,78 a & $20,88 \mathrm{a}$ & $Y=29,3772-0,10 x$ & $\mathrm{R}^{2}=99,98 \%$ \\
\hline Julho & $23,15 \mathrm{~b}$ & $18,96 \mathrm{~b}$ & $16,38 \mathrm{~b}$ & $Y=26,2640-0,12 x$ & $\mathrm{R}^{2}=98,16 \%$ \\
\hline Setembro & $19,12 \mathrm{c}$ & $18,69 \mathrm{~b}$ & $21,18 \mathrm{a}$ & $Y=22,46-0,17 x+0,0019 x^{2}$ & $\mathrm{R}^{2}=100,00 \%$ \\
\hline Época de & \multicolumn{5}{|c|}{ Área foliar $\left(\mathrm{cm}^{2}\right)$} \\
\hline plantio & \multicolumn{3}{|c|}{ Dias após a instalação } & \multirow{2}{*}{\multicolumn{2}{|c|}{$\begin{array}{c}\text { Equações de ajustes e } \\
\text { coeficientes de determinação }\end{array}$}} \\
\hline tubérculos & 28 dias & 56 dias & 84 dias & & \\
\hline Maio & $194.27 \mathrm{~b}$ & $281,78 \mathrm{~b}$ & $328,26 \mathrm{~b}$ & $Y=134,11+2,39 x$ & $R^{2}=96,97 \%$ \\
\hline Julho & $87,73 \mathrm{c}$ & $138,04 \mathrm{c}$ & $93,54 \mathrm{c}$ & $Y=-57,38+6,87 x-0,06 x^{2}$ & $\mathrm{R}^{2}=100,00 \%$ \\
\hline Setembro & $233,40 \mathrm{a}$ & $316,97 \mathrm{a}$ & $404,84 \mathrm{a}$ & $Y=146,96+3,66 x$ & $\mathrm{R}^{2}=99,98 \%$ \\
\hline \multicolumn{6}{|c|}{$\begin{array}{l}1 \text { Os dados foram transformados em raiz de } \mathrm{x}+1 \text { para análise estatística mas são apresentados } \\
\text { os dados originais. } \\
2 \text { Equações de regressão e coeficientes de determinação para o efeito da época de amostragem } \\
\text { dentro de cada época de plantio do disseminulo de tiririca } \\
{ }^{3} \text { Médias seguidas pela mesma letra minúscula, na coluna, que comparam o efeito da época de } \\
\text { plantio dos tubérculos de tiririca dentro de cada época de amostragem, não diferem entre si } \\
\text { pelo teste de Tukey a } 5 \% \text {. }\end{array}$} \\
\hline
\end{tabular}


Tabela 23. Efeito da interação entre época de plantio dos tubérculos de tiririca e época de avaliação nas biomassas fresca de folhas e fresca e seca da parte aérea total.

\begin{tabular}{|c|c|c|c|c|c|}
\hline \multirow{2}{*}{$\begin{array}{l}\text { Época de plantio } \\
\text { dos tubérculos }\end{array}$} & \multicolumn{3}{|c|}{ Biomassa fresca de folhas (g) } & \multirow{2}{*}{\multicolumn{2}{|c|}{$\begin{array}{c}\text { Equações de ajuste e } \\
\text { coeficiente de determinação }{ }^{1}\end{array}$}} \\
\hline & 28 dias & 56 dias & 84 dias & & \\
\hline Maio & $9,64 \mathrm{ab}^{2}$ & $13,15 \mathrm{~b}$ & $13,86 \mathrm{~b}$ & $\mathrm{Y}=7,99+0,076 \mathrm{x}$ & $\mathrm{R}^{2}=87,27 \%$ \\
\hline Julho & $10,80 \mathrm{a}$ & $5,74 \mathrm{c}$ & $4,33 \mathrm{~b}$ & $Y=13,43-0,116 x$ & $\mathrm{R}^{2}=90,42 \%$ \\
\hline Setembro & $9,57 \mathrm{~b}$ & $14,94 \mathrm{a}$ & $16,87 \mathrm{a}$ & $Y=6,50+0,13 x$ & $R^{2}=93,07 \%$ \\
\hline Época de plantio & \multicolumn{3}{|c|}{ Biomassa fresca da parte aérea (g) } & \multicolumn{2}{|c|}{ Equações de ajuste e } \\
\hline dos tubérculos & 28 dias & 56 dias & 84 dias & \multicolumn{2}{|c|}{ coeficiente de determinação } \\
\hline Maio & $9,64 \mathrm{a}$ & $14,60 \mathrm{~b}$ & $15,05 \mathrm{~b}$ & $Y=7,78+0,097 x$ & $\mathrm{R}^{2}=77,04 \%$ \\
\hline Julho & $10,80 \mathrm{a}$ & $5,82 \mathrm{c}$ & $4,47 \mathrm{c}$ & $Y=13,36-0,11 x$ & $\mathrm{R}^{2}=90,11 \%$ \\
\hline Setembro & $10,73 \mathrm{a}$ & $20,77 \mathrm{a}$ & $22,34 \mathrm{a}$ & $Y=6,34+0,21 x$ & $\mathrm{R}^{2}=84,90 \%$ \\
\hline Época de plantio & \multicolumn{3}{|c|}{ Biomassa fresca de folhas (g) } & \multirow{2}{*}{\multicolumn{2}{|c|}{$\begin{array}{c}\text { Equações de ajuste e } \\
\text { coeficiente de determinação }\end{array}$}} \\
\hline dos tubérculos & 28 dias & 56 dias & 84 dias & & \\
\hline Maio & $1,22 \mathrm{a}$ & $2,78 \mathrm{~b}$ & $2,97 \mathrm{~b}$ & $\mathrm{Y}=0,57+0,031 \mathrm{x}$ & $\mathrm{R}^{2}=82,89 \%$ \\
\hline Julho & $0,41 \mathrm{~b}$ & $1,44 \mathrm{c}$ & $1,78 \mathrm{c}$ & $Y=-0,16+0,025 x$ & $\mathrm{R}^{2}=92,33 \%$ \\
\hline Setembro & $1,32 \mathrm{a}$ & $4,00 \mathrm{a}$ & $5,56 \mathrm{a}$ & $Y=-0,62+0,076 x$ & $\mathrm{R}^{2}=97,67 \%$ \\
\hline
\end{tabular}

1 Equações de regressão e coeficientes de determinação para o efeito da época de amostragem dentro de cada época de plantio do dissemínulo de tiririca.

2 Médias seguidas pela mesma letra minúscula, na coluna, que comparam o efeito da época de plantio de tubérculos de tiririca dentro de cada época de amostragem, não diferem entre si pelo teste de Tukey a $5 \%$. 


\section{CONCLUSÕES GERAIS}

Concluiu-se que:

1 De modo geral, o tamanho maior dos dissemínulos favoreceu o desenvolvimento da parte subterrânea sendo observado que plantas originadas de tubérculos de tamanho grande produziram maior número de rizomas e de tubérculos + bulbos basais e apresentaram maiores biomassas fresca e seca.

2 O número de brotações emergidas não foi afetado pelo tamanho de tubérculos; mas a altura, área foliar e as biomassas fresca e seca das folhas e parte aérea foram maiores quando originadas de tubérculos de tamanho grande.

3 A adição de quantidades crescentes de palha de cana-de-açúcar causou redução no desenvolvimento de rizoma e de tubérculos + bulbos basais.

4 A adição de palha de cana-de-açúcar afetou mais a brotação e a emergência da parte aérea de originadas de tubérculos pequenos quando comparadas aos grandes. A adição de palha reduziu a biomassa fresca e seca das folhas e da parte aérea total em valores variando de 5,0 a 11,0 t/ha.

5 Os tubérculos plantados em maio emergiram em menos tempo e mais uniformemente que os de julho e setembro.

6 O plantio realizado em setembro possibilitou ocorrência de plantas com maior número de rizomas e de tubérculos + bulbos basais, de brotações, área foliar e biomassas fresca e seca de raizes, rizomas, folhas e parte aérea total. Para altura média e biomassa fresca de tubérculos, os melhores resultados foram observados na instalação de maio. Para todas as variáveis analisadas, o plantio dos tubérculos 
realizado em julho apresentou sempre os menores valores.

7 Para o efeito de época de avaliação foram observados aumentos lineares em função do tempo para todas as variáveis analisadas. 


\section{REFERÊNCIAS BIBLIOGRÁFICAS}

ABRAMO FILHO, J.; MATSUOKA, S.; SPERANDIO, M.L.; RODRIGUES, R.C.D.; MARCHETTI, L.L. Resíduos da colheita mecanizada de cana crua. Álcool \& Açúcar, v.67, p.23-25, 1993.

ALM, D.M.; STOLLER, E.W; WAX, L.M. An index model for predicting seed germination and emergence rates. Weed Technology, v.7, p.560-569, 1993.

ALMEIDA, F.S. Controle de ervas. In: FUNDAÇÃO INSTITUTO AGRONÔMICO DO PARANÁ Plantio direto no Estado do Paraná. Londrina: IAPAR. 1981. 244p. (Circular, 23):

ALMEIDA. F.S. ; RODRIGUES, B.N. Guia de herbicidas: contribuição para o uso adequado em plantio direto e convencional. Londrina: Fundação Instituto Agronômico do Paraná, 1985. 482p.

ALVAREZ, I.A.A. ; CASTRO, P.R.C. Crescimento da parte aérea de cana crua e queimada. Scientia Agricola, v. 56, p.1069-1079, 1999.

ANDERSEN, R.N. Influence of soybean seed size on response to atrazine. Weed Science, v.18, p. 162-164, 1970.

ARÉVALO, R.A. Manejo de plantas daninhas em áreas de colheita de cana crua. In: SEMANA DA CANA-DE-AÇÚCAR DE PIRACICABA, 3., Piracicaba, 1997. Anais. Piracicaba: STAB-SECAPI, 1998. p.26-28.

ARÉVALO, R.A. ; BERTONCINI, E.I. Manejo químico de plantas daninhas nos resíduos de colheita de cana crua. STAB, v.17, p.36-38, 1999. 
AZANIA, A.A.P.M.; AZANIA, C.A.M.; GRAVENA, R.; PAVANI, M.C.M.D. PITELLI, R.A. Influência da palha de cana-de-açúcar (Saccharum spp) na emergência de espécies de plantas daninhas da família Convolvulaceae. Planta Daninha, v.20, p.207-212, 2002.

BAKER, H.G. Seed weight in relation to environmental conditions in California. Ecology, v.53, p.997-1010, 1972.

BALBINOT JÚNIOR, A. A.; FLECK, N.G.; AGOSTINETTO, D.; RIZZARDI, M. A.; MEROTTO JÚNIOR, A.; VIDAL, R. A. Velocidade de emergência e crescimento inicial de cultivares de arroz irrigado influenciando a competitividade com plantas daninhas. Planta Daninha, v.19, p.305-316, 2001.

BARUIAN, J.V.; REDDY, K.N.; WILLS, G.D. Glyphosate injury, rainfastness, absorption, and translocation in purple nutsedge (Cyperus rotundus). Weed Technology, v.13, p.112-119, 1999.

BENDIXEN, L.E. Cytokinin effects induced in purple nutsedge by perfluidone. Weed Science, v.23, p.445-447, 1975.

BENDIXEN, L.E. ; NANDIHALLI, U.B. Worldwide distribution of purple and yellow nutsedge (Cyperus rotundus and C. esculentus). Weed Technology, v.1, p.61-65, 1987.

BETRIA, A.I. ; MONTALDI, E.R. Tuber production by purple nutgrass (Cyperus rotundus L.) in darkness. Weed Research, v.1, p.73-76, 1975.

BEVERIDGE, J.L. ; WILSIE, C.P. Influence of depth of planting, seed size, and variety on emergence and seedling vigor in alfalfa. Agronomy Journal, v.51, p.731-734, 1959.

BHARDWAJ, R.B.L. ; VERMA, R.D. Seasonal development of nutgrass (Cyperus rotundus L.) under Delhi conditions. Indian Journal of Agricultural Science, v.38, p.950-957, 1968. 
BLACK JUNIOR, C.C.; CHEN, I.M.; BROWN, R.N. Biochemical basis for plant competition. Weed Science, v.17, p.338-344, 1969.

BLACK, J.N. The influence of seed size and depth of sowing on preemergence and early vegetative growth of subterranean clover (Trifolium subterraneun L.). Australian Journal of Agricultural Research, v.7, p.98-109, 1956.

BLACK, J.N. The early vegetative growth of three strains of subterranean clover (Trifolium subterraneum L.) in relation to size of seed. Australian Journal of Agriculture Research, v.8, p.1-14, 1957a.

BLACK, J.N. The influence of varying light intensity on the growth of herbage plants. Herbage Abstracts, v.27, p.89, 1957b.

BLACK, J.N. Seed size as a factor in the growth of subterranean clover (Trifolium subterraneum) under spaced and sward conditions. Australian Journal of Agriculture Research, v.8, p.335-351, 1957c.

BLACK, J.N. Competition between plants of different initial seed sizes in swards of subterranean clover (Trifolium subterraneum L.) with particular reference to leaf area and the light microclimate. Australian Journal of Agricultural Research, v.9, p.299-318, 1958.

BLANCO, H.G; ARÉVALO, R.A.; CHIBA, S. Convivência de populações de Cyperus rotundus L. com plantas de algodoeiro herbáceo. Pesquisa Agropecuária Brasileira, v.26, p.169-176, 1991.

BLEVINS, R.L.; COOK, D.; PHILLIPS, S.H.; PHILLIPS, R.E. Influence of no-tillage on soil moisture. Agronomy Journal, v. 63, p.593-596, 1971.

BREDEMEIER, C.; MUNDSTOCK, C.M.; BÜTTENBENDER, D. Efeito do tamanho das sementes de trigo no desenvolvimento inicial das plantas e no rendimento dos grãos. Pesquisa Agropecuária Brasileira, v.36, p.1061-1068, 2001. 
BREMNER, P.M.; ECKERSALL, R.N.; SCOTT, R.K. The relative importance of embryo size and endosperm size in causing the effects associated with seed size in wheat. Journal of Agricultural Science, v.61, p.139-145, 1963.

BRIGHENTI, A.M.; SILVA, J.F.; SEDIYAMA, T.; SILVEIRA, J.S.M.; SEDIYAMA, C.S. Análise de crescimento da tiririca (Cyperus rotunds L.). Revista Ceres, v.44, p.94110, 1997a.

BRIGHENTI, A.M.; SILVA, J.F.; SEDIYAMA, T.; SILVEIRA, J.S.M.; SEDIYAMA, C.S. Manejo da tiririca em cultivos sucessivos de milho e feijão. Revista de Agricultura, v.72, p.331-349, 1997b.

BURRIS, J.S.; WAHAB, A.H.; EDJE, O.T. Effects of seed size on seedling performance in soybeans. I. Seedling growth and respiration in the dark. Crop Science, v.11, p.492-496, 1971.

BURRIS, J.S. ; EDJE, O.T.; WAHAB, A.H. Effects of seed size on seedling performance in soybeans. II. Seedling growth and photosynthesis and field performance. Crop Science, v.13, p.207-210, 1973.

CASTRO, P.R.C.; RODRIGUES, J.D.; MORAES, M.A.; CARVALHO, V.L.M. Efeitos alelopáticos de alguns extratos vegetais na germinação do tomateiro (Lycopersicon esculentum Mill. cv. Santa Cruz). Planta Daninha, v.6, p.79-85, 1983.

CAZETTA, J.O.; SADER, R.; IKEDA, M. Efeito do tamanho no desempenho germinativo de sementes de feijoeiro (Phaseolus vulgaris L.). Cientifica, v.23, p.65-71, 1995.

CENTRO INTERNACIONAL DE AGRICULTURA TROPICAL (CIAT) Annual Report, 1974. Cali: CIAT, 1975. 260p.

CHETRAM R.S. ; BENDIXEN, L.E. Phytochrome controlled basal bulb formation in purple nutsedge. Weed Science, v.22, p.269-272, 1974.

CORREIA, N.M. ; DURIGAN, J.C. Emergência de plantas daninhas em solo coberto com palha de cana-de-açúcar. Planta Daninha, v.22, p.11-17, 2004. 
COSTA , A.V.; FONTES, L.A.N.; SEDIYAMA, T.; GALVÃO, J.D. Efeito da profundidade de plantio e do tamanho da semente sobre a emergência e sobre algumas características agronômicas da soja. Experimentiae, v.16, p.151-172, 1973.

CRUZ, A.P.F. A tutela penal das queimadas: o problema da cana-de-açúcar no nordeste paulista. Justitia: matérias aprovadas para publicação futura. sd. 16p.

CRUZ, L.S.P.; WEICHERT, M.A., UCHÔA, P.L. Avaliação da ação de imazapyr no controle da tiririca (Cyperus rotundus L.) em cana-de-açúcar. STAB, v.12, p.40-44, 1993.

CUDNEY, D. Nutsedge: history, economic importance, and distribution. In: NUTSEDGE MANAGMENT WORKSHOP: a day with the world's worst weed. Riverside: University of California, 1997. p.2-3.

DAY, B.E.. ; RUSSELL, R.C. The effect of drying on survival of nutgrass tubers. California Agricultural Experiment Station/University of California/College of Agriculture, 1955. 8p. (Bulletin, 751).

DURIGAN, J.C. Manejo da tiririca (Cyperus rotundus L.) antes e durante a implantação da cultura de cana-de-açúcar (Saccharum spp). Jaboticabal, 1991. 336p. Tese (Livre-Docência). Faculdade de Ciências Agrárias e Veterinárias, Universidade Estadual Paulista “Júlio de Mesquita Filho".

EAMES, A.J. Comparative effects of spray treatments with growth-regulating substances on the nut grass, Cyperus rotundus L., and anatomical modifications following treament with butyl 2,4-dichlorophenoxyacetate. American Journal of Botany, v.36, p.571-584, 1949.

EDWARDS JUNIOR, C.J. ; HARTWIG, E.E. Effect of seed size upon rate of germination in soybeans. Agronomy Journal, v.63, p.429-430, 1971.

ERICKSON, L.C. The effect of alfalfa seed size and depth of seeding upon the subsequent procurement of stand. Journal of American Society of Agronomy, v.38, p.964-973, 1946. 
EVANS, L.E. ; BHATT, G.M. Influence of seed size, protein content, and cultivar on early seedling vigor in wheat. Canadian Journal of Plant Science, v.57, p.929936, 1977.

FACELLI, J.M. ; PICKETT, S.T.A. Plant litter: light interception and effects of an oldfield plant community. Ecology, v.72, p.1024-1031, 1991.

FEHR, W.R. ; PROBST, A. H. Effect of seed source on soybean strain performance for two sucessive generations. Crop Science, v.11, p.865-867, 1971.

FENNER, M. Germination tests on thirty-two East African weed species. Weed Research, v.20, p.135-138,1980.

FENNER, M. Relationships between seed weight, ash content and seedling growth in twenty-four species of Compositae. New Phytologist, v.95, p.697-706, 1983.

FERNANDES-QUINTANILLA, C. Studying the population dynamics of weeds. Weed Research, v.28, p.443-447, 1988.

FIGUEIREDO, M.S. ; VIEIRA, C. Efeito do tamanho das sementes sobre o "stand", produção e altura das plantas, na cultura do feijão (Phaseolus vulgaris L.). Revista Ceres, v.17, p.47-60, 1970.

FIRBANK, L.G. ; WATKINSON, A.R. On the analysis of competition within two-species mixtures of plants. Journal of Applied Ecology, v.22, p.503-517, 1985.

FISHER, J.B. Control of the internodal intercalary meristem of Cyperus alternifolius. American Journal of Botany, v.57, p.1017-1026, 1970.

FISHER, J.B. Control of bud inhibition in Cyperus. Planta, v.97, p.257-268, 1971.

FRIEDMAN, T. ; HOROWITZ, M. Phytotoxicity of subterranean residues of three perennial weeds. Weed Research, v. 10, p.382-385, 1970. 
FRIEDMAN, T. ; HOROWITZ, M. Biologically active substances in subterranean parts of purple nutsedge. Weed Science, v.19, p.398-401, 1971.

FRIESEN, G.H. ; HAMILL, A.S. Sprouting and development of yellow nut sedge tubers. Canadian Journal of Plant Science, v.57, p.509-514, 1977.

FURLANI NETO, V.L. Colheita mecanizada da cana-de-açúcar. STAB, v.12, p.8-9, 1994.

GARG, D.K.; BENDIXEN, L.E.; ANDERSON, S.R. Rhizome differentiation in yellow nutsedge. Weeds, v.15, p.124-128, 1967.

GELMOND, H. Physiological aspects of seed germination. Seed Science and Technology, v.6, p.625-639, 1978.

GONÇALVES, D.B. A regulamentação das queimadas e as mudanças nos canaviais paulistas. São Carlos: RiMa, 2002. 127p.

GONÇALVES, J.S. ; SOUZA, S.A.M. Proibição da queima de cana no Estado de São Paulo: simulações dos efeitos na área cultivada e na demanda pela força de trabalho. Informações Econômicas, v.28, p.21-40, 1998.

GROSS, K.L. Effects of seed size and growth form on seedling establishment of six monocarpic perennial plants. Journal of Ecology, v. 72, p.369-387, 1984.

GUEDES, S.N.R. ; RÉ, R.M. Os determinantes da decisão microeconômica de mecanizar o corte da cana: um estudo de caso. Piracicaba: UNIMEP, 2000. 8p. <http://www.unimep.br/fgn/economia/ecosober.html>. [6 mar. 2003].

HAMMERTON, J.L. Studies on weed species on the genus Polygonum L. IV. Variations in seed weight and germination behaviour in P. lapathifolium. Weed Reseach, v.7, p.1-21, 1967a. 
HAMMERTON, J.L. Studies on weed species on the genus Polygonum L. V. Variations in seed weight, germination behaviour and seed polymorphism in P. persicaria. Weed Reseach, v.7, p.331-348, 1967b.

HAMMERTON, J.L. Experiments with Cyperus rotundus L. I. Growth and development and effects of 2,4-D and paraquat. Weed Research, v.14, p.365-370, 1974.

HAMMERTON, J.L. Experiments with Cyperus rotundus L. II. Effects of some herbicides and growth regulators. Weed Research, v.15, p.177-183, 1975a.

HAMMERTON, J.L. Experiments with Cyperus rotundus L. III. Seasonal variations in growth. Weed Research, v.15, p.339-348, 1975b.

HAMMERTON, J.L. Effects of desiccation, chemicals and defoliation on nutgrass (Cyperus rotundus L.). In: BRAITHWAITE, C.W.D; PHELPS, R.H. ; BENNETT, F.D. Crop protection in the Caribbean. Trinidad: University of West Indies. p.195-209. 1975c.

HARPER, J.L.; LOVELL, P.H.; MOORE, K.G. The shapes and sizes of seeds. Annual Review of Ecology and Systematics, v.1, p.327-356, 1970.

HAUSER, E.W. Development of purple nutsedge under field conditions. Weeds, v.10, p.315-321, 1962a.

HAUSER, E. W. The establishment of nutsedge from space-planted tubers. Weeds, v.10, p.209-212, 1962b.

HERNANDEZ, D.D.; ALVES, P.L.C.A.; MARTINS, J.V.F. Influência do resíduo da colheita de cana-de-açúcar sem queima sobre a eficiência dos herbicidas imazapic e imazapic + pendimethalin. Planta Daninha, v.19, p.419-426, 2001.

HOLM, L.G.; PLUCKETT, D.L., PANCHO, J.W.; HERBERGER, J.P. The world's worst weeds: distribution and biology. Honolulu: Univ. Press Hawaii, 1977. 609p. 
HOLT, J. Biology of nutsedge. In: NUTSEDGE MANAGMENT WORKSHOP: a day with the world's worst weed, Riverside: University of California, 1997. p.4.

HOLT, J.S. ; ORCUTT, D.R. Functional relationships of growth and competitiveness in perennial weeds and cotton (Gossypium hirsutum). Weed Science, v.39, p.575-584, 1991.

HOPPER, N.W.; OVERHOLT, J.R.; MARTIN, J.R. Effect of cultivar, temperature and seed size on the germination and emergence of soya beans (Glycine max (L.) Merr.). Annals of Botany, v.44, p.301-308, 1979.

HOROWITZ, M. Effects of frequent clipping on three perennial weeds, Cynodon dactylon (L.) Pers., Sorghum halepense (L.) Pers. and Cyperus rotundus L. Experimental Agriculture, v.8, p.225-234, 1972a.

HOROWITZ, M. Growth, tuber formation and spread of Cyperus rotundus from single tubers. Weed Research, v.12, p.348-363, 1972b.

HOROWITZ, M. Competitive effects of three perennial weeds, Cynodon dactylon (L.) Pers., Cyperus rotundus L. and Sorghum halepense (L.) Pers., on young citrus. Journal of Horticultural Science, v.48, p.135-147, 1973.

JACKSON, N.E. Nutsedge in turfgrass: distribution and management in residential and commercial turfgrass. In: NUTSEGDE MANAGEMENT WORKSHOP. Riverside, University of California, 1997. p.4-5.

JANSEN, L.L. Morphology and photoperiodic responses of yellow nutsedge. Weed Science, v. 19, p. 210-219, 1971.

JORDAN-MOLERO, J.E. ; STOLLER, E.W. Seasonal development of yellow and purple nutsedges (Cyperus esculentus and C. rotundus) in Illinois. Weed Science, v.26, p.614-618, 1978.

JURADO, E ; WESTOBY, M. Seedling growth in relation to seed size among species of arid Australia. Journal of Ecology, v.80, p.407-416, 1992. 
JUSTICE, O.L. ; WHITEHEAD, M.O. Seed production, viabilitity, and dormancy in the nutgrasses Cyperus rotundus and C. esculentus. Journal of Agricultural Research, v.7, p.303-318, 1946.

KEELEY, P.E. Interference and interaction of purple and yellow nutsedges (Cyperus rotundus and C. esculentus) with crops. Weed Technology, v.1, p.74-81, 1987.

KISSMAN, K.G. Plantas infestantes e nocivas. 2. ed. São Paulo: Basf, 1997. v.1. p.222-229.

KUVA, M.A.; PITELlI, R.A.; CHRISTOFFOLETI, P.J.; ALVES, P.L.C.A. Períodos de interferência das plantas daninhas na cultura da cana-de-açúcar. I - Tiririca. Planta Daninha, v.18, p.241-251, 2000.

LAFOND, G.P. ; BAKER, R.J. Effects of genotype and seed size on speed of emergence and seedling vigor in nine spring wheat cultivars. Crop Science, v. 26, p.341-346, 1986.

LAWSON, E.H. ; ROSSITER, R.C. The influence of seed size and seeding rate on the growth of two strains of subterranean clover (Trifolium subterrraneum L.). Australian Journal of Agricultural Research, v.9, p.286-298, 1958.

LEISHMAN, M.R. ; WESTOBY, M. The role of seed size in seedling establishment in dry soil conditions - experimental evidence from semi-arid species. Journal of Ecology, v.82, p.249-258, 1994.

LIU, M.C. ; OWEN, M.D.K. Effect of seed reserve utilization on wooly cupgrass (Eriochloa villosa) development. Weed Science, v.51, p.78-82, 2003.

LÓPES-CASTAÑEDA, C.; RICHARDS, R.A.; FARQUHAR, G.D.; WILLIAMSON, R.E. Seed and seedling characteristics contributing to variation in early vigor among temperate cereals. Crop Science, v.36, p.1257-1266, 1996. 
LORENZI, H. Controle de plantas daninhas em cana-de-açúcar. IN: SEMINÁRIO DE TECNOLOGIA AGRONÔMICA, Piracicaba, 1982. Anais. Piracicaba: Centro de Tecnologia da Copersucar, 1982. p.179-188.

LORENZI, H. Plantas daninhas do Brasil: terrestres, aquáticas, parasitas e tóxicas. 3. ed. Nova Odessa: Instituto Plantarum, 2000. p.251.

LORENZI, H.J.; BRUNELLI NETO, V.; OLIVEIRA, J.E. Estudo do efeito do herbicida oxyfluorfen, aplicado em pré-emergência, sobre o crescimento e produtividade da cana-de-açúcar (Saccharum officinarum) cv. SP71-6163. STAB, v.12, p.24-26, 1994.

LOWE, L.B. ; RIES, S.K. Endosperm protein of wheat seed as a determinant of seedling growth. Plant Physiology, v.51, p.57-60, 1973.

MARTINS, C.C. ; SILVA, W.R. Estudos de banco de sementes no solo. Informativo ABRATES, v.4, p.49-56, 1994.

MARTINS, D.; VELINI, E.D.; MARTINS, C.; SOUZA, L.S. Emergência em campo de dicotiledôneas infestantes em solo coberto com palha de cana-de-açúcar. Planta Daninha, v.17, p.151-161, 1999.

MASCARENHAS, M.H.T.; GALLI, A.J.B.; VIANA, M.C.M.; MACEDO, G.A.R.; LARA, J.F.R. Eficácia do halosulfuron no controle de tiririca (Cyperus rotundus) na cultura da cana-de-açúcar. Planta Daninha, v. 13, n.2, p.69-80, 1995.

MATTHIESEN, R.L. ; STOLLER, E.W. Tuber composition in yellow nutsedge (Cyperus esculentus) variants. Weed Research, v. 18, p.373-377, 1978.

MATTOS, E.D.; ALVES, P.L.C.A.; MÔRO, F.V.; SOUZA, J.C.; MARTINS, J.V.F.; RIGLER NETO, F. Controle químico de parreira-brava (Cissampelos glaberrima). Revista Brasileira de Herbicidas, v.2, p.57-64, 2001. 
MAUN, M.A. ; CAVERS, P.B. Seed production and dormancy in Rumex crispus. I. The effects of removal of cauline leaves at anthesis. Canadian Journal of Botany, v.49, p.1123-1130, 1971.

McGIFFEN JUNIOR, M.E. Alternatives for purple and yellow nutsedge management. In: NUTSEDGE MANAGMENT WORKSHOP: a day with the world's worst weed. Riverside: University of California, 1997. p. 9-10.

McWILLIAMS, E.L.; LANDERS, R.Q.; MAHLSTEDE, J.P. Variation in seed weight and germination in population of Amaranthus retroflexus L. Ecology, v.49, p.290-296, 1968.

MEDEIROS, D. Efeitos da palha de cana-de-açúcar (Saccharum spp.) sobre o manejo de plantas daninhas e dinâmica do banco de sementes. Piracicaba, 2001. 126p. Dissertação (Mestrado) - Escola Superior de Agricultura "Luiz de Queiróz", Universidade de São Paulo.

MERO-MACIAS, H. The weedy nutsedges (Cyperus spp) outline. Iowa State University, 1996. http://www.public.iastate.edu/ jdekker/u4nutsg1.html. [21 maio 1997].

MIAN, M.A.R. ; NAFZIGER, E.D. Seed size and water potential effects on germination and seedling growth of winter wheat. Crop Science, v.34, p.169-171, 1994.

MILES, J.E.; NISHIMOTO, R.K.; KAWABATA, O. Diurnally alternating temperatures stimulate sprouting of purple nutsedge (Cyperus rotundus) tubers. Weed Science, v.44, p.122-125, 1996.

MILES, J.E.; KAWABATA, O.; NISHIMOTO, R. K. Modelling purple nutsedge sprouting under soil solarization. Weed Science, v.50, p.64-71, 2002.

MOHLER, C.L. ; TEASDALE, J.R. Response of weed emergence to rate of Vicia villosa Roth and Secale cereale L. residue. Weed Research, v.33, p.487-499, 1993. 
MOHLER, C.L. ; GALFORD, A.E. Weed seedling emergence and seed survival: separating the effects of seed position and soil modification by tillage. Weed Research, v.37, p.139-155, 1997.

MORTON, C.T. ; BUCHELE, W.F. Emergence energy of plant seedlings. Agricultural Engineering, v.41, p.428-455, 1960.

NEESER, C.; AGUERO, R.; SWANTON, C.J. Survival and dormancy of purple nutsedge (Cyperus rotundus) tubers. Weed Science, v. 45, p.784-790, 1997.

NISHIMOTO, R.K. Cyperus rotundus L.: current and needed research on its biology. In: THIRD INTERNATIONAL WEED SCIENCE CONGRESS, Fóz do Iguassu, 2000. Abstracts. Corvallis: International Weed Science Society, 2000. p.255-256.

OGG JUNIOR, A.G. ; DAWSON, J.H. Time of emergence of eight weed species. Weed Science, v.32, p.327-335, 1984.

OHIRA, S.; HASEGAWA, T.; HAYASHI, K.I.; HOSHINO, T.; TAKAOKA, D.; NOZAKI, H. Sesquiterpenoids from Cyperus rotundus. Phytochemistry, v.47, p.1577-1581, 1981.

OKASAWA, Y.; CHAPMAN, H.W. Regulation of tuber formation in the potato plant. Physiologia Plantarum, v.15, p.413-419, 1962.

OKOLI, C.A.N.; SHILlING, D.G.; SMITH, R.L.; BEWICK, T.A. Genetic diversity in purple nutsedge (Cyperus rotundus L.) and yellow nutsedge (Cyperus esculentus L.). Biological Control, v.8, p.111-118, 1997.

OMETTO, M.C. Desempenho da colhedora ENGEAGRO. STAB, v.12, p.21-24, 1994.

PANDEY, H.N. ; DUBEY, S.K. Achene germination of Parthenium hysterophorus L.: effects of light, temperature, provenance and achene size. Weed Research, v.28, p.185-190, 1988. 
PATTERSON, D.T. Shading responses of purple and yellow nutsedges (Cyperus rotundus and C. esculentus). Weed Science, v.30, p.25-30, 1982.

PERIN, A.; ARAÚJO, A.P.; TEIXEIRA, M.G. Efeito do tamanho da semente na acumulação de biomassa e nutrientes e na produtividade do feijoeiro. Pesquisa Agropecuária Brasileira, v.37, p.1711-1718, 2002.

PITELKA, L.F.; THAYER, M.E.; HANSEN, S.B. Variation in achene weight in Aster acuminatus. Canadian Journal of Botany, v.61, p.1415-1420, 1983.

PITELLI, R.A. Interferência de plantas daninhas em culturas agrícolas. Informe Agropecuário, v.11, p.16-27, 1985.

PITELLI, R.A. Dinâmica de plantas daninhas no sistema de plantio direto. In: CONGRESSO BRASILEIRO DA CIENCIA DAS PLANTAS DANINHAS, 20. Florianópolis, 1995. Palestras. Londrina: SBCPD, 1995. p. 5-12.

POLLOCK, C.J. The response of plants to temperature change. Journal of Agricultural Science, v.115, p.1-5, 1990.

POPINIGIS, F. Fisiologia da semente. Brasília: Ministério da Agricultura/ Agiplan/ Banco Interamericano de Desenvolvimento, 1977. 289p.

PROCÓPIO, S.O.; SILVA, A.A.; ARAÚJO, E.F.; RIBEIRO JÚNIOR, J.I.; FERREIRA, L.R. Efeito do tamanho de sementes sobre a tolerância do feijoeiro ao s-metolachlor em condições de baixa temperatura. Revista Brasileira de Herbicidas, v.2, p.133-141, 2001.

QUINTELA, A.C.R.; ANDRADE, L.A.B.; CORRÊA, J.B.D.; RESENDE, P.M.; VIEIRA, G.G. Controle de plantas daninhas em cana crua (cultivar RB 8835089) no sistema integrado palhiço, herbicida e vinhaça. STAB, v.20, p.38-42, 2002.

RADOSEVICH, S.R. ; HOLT, J.S. Weed ecology: implications for vegetation management. New York: John Wiley, 1984. p.195-241. 
RAMIREZ, S.A. ; BENDIXEN, L.E. Espécies de Cyperus como hospedeiro de artrópodos y nematodos destructivos de cultivos. In: CONGRESSO BRASILEIRO DE HERBICIDAS E ERVAS DANINHAS, 14 ; CONGRESO DE LA ASOCIACIÓN LATINOAMERICANA DE MALEZAS, 6, Campinas, 1982. Resumos. São Paulo: Sociedade Brasileiro de Herbicidas e Ervas Daninhas. 1982. p.13.

RATNAYAKE, S. ; SHAW, D.R. Influence of seed vigor, herbicides rates, and incorporation depths on emergence and seedling development of soybean (Glycine max). Weed Technology, v.6, p.801-806, 1992.

READER, R.J. Control of seedling emergence by ground cover and seed predation in relation to seed size for some old-field species. Journal of Ecology, v. 81, p.169175, 1993.

REDDY, K.N. Impact of rye cover crop and herbicides on weeds, yield, and net return in narrow-row transgenic and conventional soybean (Glycine max). Weed Technology, v.17, p.28-35, 2003.

REUNiÃo DE PESQUiSA DE SOJA DA REGIÃO SUL, 28., Santa Maria, 2000. Anais. Santa Maria: UFSM/CCR/Departamento de Defesa Fitossanitária, 2000. 148p.

RODRIGUES, B.N.; LIMA, J.; YADA, I.F.V.; FORNAROLLI, D.A. Influência da cobertura morta no comportamento do herbicida trifluralin. Planta Daninha, v.16, p.163173, 1998.

ROGLER, G.A. Seed size and seedling vigor in crested wheatgrass.

Agronomy Journal, v.46, p.216-220, 1954.

ROWSELL, J.; BOWMAN, M.; FALK, D.; SZLAVNICS, Z.; SMID, A.; HORN, J.; HOEKSTRA, G.; WIGHTMAN, C. Spring wheat seed size, seed treatment rate and seeding rate. Guelph: University of Guelph, 2003. 9p. (Final Report, NLARS Report, 2003-2).

ROZEFF, N. Harvest comparisons of green and burned sugarcane in Texas. International Sugar Journal, v. 97, p.501-506, 1995. 
RUIZ DE CLAVIJO, E. Role of within-individual variation in capitulum size and achene mass in the adaptation of the annual Centaurea eriphora to varying water supply in a Mediterranean environment. Annals of Botany, v.90, p.279-286, 2002.

SALTON, J.C. ; MIELNICKZUK, J. Relações entre sistemas de preparo, temperatura e umidade de um podzólico vermelho escuro de Eldorado do Sul (RS). Revista Brasileira de Ciência do Solo, v.19, p.313-319, 1995.

SCHAAL, B.A. Reproductive capacity and seed size in Lupinus texensis. American Journal of Botany, v.67, p.703-709, 1980.

SCHIMPF, D.J. Seed weigth of Amaranthus retroflexus in relation to moisture and length of growing season. Ecology, v.58, p.450-453, 1977.

SEIBERT, A.C. ; PEARCE, R.B. Growth analysis of weed and crop species with reference to seed weight. Weed Science, v.41, p.52-56, 1993.

SEIFERT, G. ; VOLL, E. Cobertura de aveia e calagem sobre amendoim-bravo em semeadura direta de soja. Planta Daninha, v.18, p.309-322, 2000.

SHAMSI, S.R.A.; AL-ALI, F.A.; HUSSAIN, S.M. Temperature and light requirements for the sprouting of chilled and unchilled tubers of the purple nutsedge, Cyperus rotundus. Physiologia Plantarum, v.44, p.193-196, 1978.

SILVA, J.R.V.; COSTA, N.V.; MARTINS, D. Efeito da palhada de cultivares de cana-deaçúcar na emergência de Cyperus rotundus L.. Planta Daninha, v. 21, p. 375-380, 2003.

SINGH, S.P. Presence of a growth inhibitor in the tubers of nutgrass (Cyperus rotundus L.) Proceeding of Indian Academic Science, v.67, p.18-23, 1968.

SIRIWARDANA, G. ; NISHIMOTO, R.K. Propagules of purple nutsedge (Cyperus rotundus L.) in soil. Weed Technology, v.1, p.217-220, 1987. 
SMITH, E.V. ; MAYTON, E.L. Nut grass eradication studies: III. The control of nut grass, Cyperus rotundus L., on several soil types by tillage. Journal of American Society of Agronomy, v.34, p. 151-159, 1942.

SMITH, T.J. ; CAMPER JR, H.M. Effects of seed size on soybean performance. Agronomy Journal, v.67, p.681-684, 1975.

STEPHENSON, A.G. Fruit set, herbivory, fruit reduction, and the fruiting strategy of Catalpa speciosa (Bignoniaceae). Ecology, v. 61, p.57-64, 1980.

STOCK, W.D.; PATE, J.S.; DELFS, J. Influence of seed size and quality on seedling development under low nutrient conditions in five Australian and South African members of the Proteaceae. Journal of Ecology, v.78, p.1005-1020, 1990.

STOLLER, E.W. ; WAX, L.M. Periodicity of germination and emergence of some annual weeds. Weed Science, v.21, p.574-580, 1973.

STOLLER, E.W. Effect of minimum soil temperature on differential distribution of Cyperus rotundus and C. esculentus in the United States. Weed Research, v.13, p.209-217, 1973.

STOLLER, E.W. ; SWEET, R.D. Biology and life cycle of purple and yellow nutsedges (Cyperus rotundus and C. esculentus). Weed Technology, v.1, p.66-73, 1987.

STOLLER, E.W. ; NEMA, D.P.; BHAN, V.M. Yellow nutsedge tuber germination and seedling development. Weed Science, v.20, p.93-97, 1972.

TANIMOTO, O.S. Plantio da soja na palha traz sustentabilidade à agricultura. Revista Cultivar, v.4, p.31-32, 2002.

TAYLORSON, R.B. ; BORTHWICK, H.A. Light filtration by foliar canopies: significance for light-controlled weed seed germination. Weed Science, v. 17, p.48-51, 1969.

TEASDALE, J.R. Contribution of cover crops to weed management in sustainable agricultural systems. Journal of Production Agriculture, v.9, p.475-479, 1996. 
TEASDALE, J.R. ; MOHLER, C.L. Light transmittance, soil temperature, and soil moisture under residue of hairy vetch and rye. Agronomy Journal, v.85, p.673680, 1993.

TEASDALE, J.R.; BESTE, C.E.; POTTS, W.E. Response of weeds to tillage and cover crop residue. Weed Science, v. 39, p.195-199, 1991.

TEMME, D.H. Seed size variability: a consequence of variable genetic quality among offspring? Evolution, v.40, p.414-417, 1986.

TEO, C.K.H.; BENDIXEN, L.E.; NISHIMOTO, R.K. Bud sprouting and growth of purple nutsedge altered by benzyladenine. Weed Science, v.21, p.19-23, 1973.

THE OJOS NEGROS RESEARCH GROUP. Coquillo facts: 3. Purple nutsedge. $<$ http://ponce.sdsu.edu/protected2/coquillofacts03.html. (2 dez. 2002).

THEISEN, G. ; VIDAL, R.A. Efeito da cobertura do solo com resíduos de aveia-preta nas etapas do ciclo de vida do capim-marmelada. Planta Daninha, v.17, p.189196, 1999a.

THEISEN, G. ; VIDAL, R.A. Viabilidade de sementes de papuã (Brachiaria plantaginea) e a cobertura do solo com palha. Ciência Rural, v.28, p.449-452, 1999b.

THEISEN, G.; VIDAL, R.A.; FLECK, N.G. Redução da infestação de Brachiaria plantaginea em soja pela cobertura do solo com palha de aveia-preta. Pesquisa Agropecuária Brasileira, v.35, p.753-756, 2000.

THUMBLESON, M.E. ; KOMMEDAHL, T. Factors affecting dormancy in tubers of Cyperus esculentus. Botanical Gazette, v. 123, p.186-190, 1962.

TREZZI, M.M. ; VIDAL, R.A. Potencial de utilização de cobertura vegetal de sorgo e milheto na supressão de plantas daninhas em condição de campo: II - Efeitos da cobertura morta. Planta Daninha, v.22, p. 1-10, 2004. 
TURNER, D.J. Agropyron repens (L.) Beauv - some aspects of rhizome fragmentation, rhizome burial and defoliation. Weed Research, v.8, p.298-308, 1968.

URBATSCH, L. ; SKINNER, M. Exotic weed species: purple nutsedge Cyperus rotundus. USDA/NRCS Plant Guide, 2000. 9p.

USTULIN, E.J. ; SEVERO, J.R. Cana de açúcar: proteger o ambiente e continuar gerando empregos. Revista Gleba, setembro de 2001. <http://www.cna.org.br/Gleba99/2001/Set/cana01.htm>. [13 mar. 2003].

UTIYAMA, S.Y.; HIDALGO, E.; SANOMYA, R.M. Eficiência do herbicida DPX-KG.333 no controle de Digitaria horizontalis em cana-de-açúcar. Saccharum, v.1, p.6, 1999.

VELINI, E.D. ; NEGRISOLI, E. Controle de plantas daninhas em canacrua. In: CONGRESSO BRASILEIRO DA CIÊNCIA DAS PLANTAS DANINHAS, 22., Fóz do Iguaçú, 2000. Palestras. Londrina: SBCPD, 2000. p. 148-164.

VENABLE, D.L. Size-number tradeoffs and the variation of seed size with plant resource status. American Naturalist, v.140, p.287-304, 1992.

VICTÓRIA FILHO, R. Potencial de ocorrência de plantas daninhas em plantio direto. IN; FANCELLI, A.L.; VIDAL TORRADO, P.; MACHADO, J. Atualização em plantio direto. Campinas: Fundação Cargill, 1985. p.31-48a.

VICTÓRIA FILHO, R. Cyperus rotundus L.: current and needed research on purple nutsedge management. In: THIRD INTERNATIONAL WEED SCIENCE CONGRESS, Fóz do Iguassu, 2000. Abstracts. Corvallis: International Weed Science Society, 2000. p. 256.

VIDAL, R.A. ; BAUMAN, T.T. Surface wheat (Triticum aestivum) residues, giant foxtail (Setaria faberi), and soybean (Glycine max) yield. Weed Science, v.44, p.939-943, 1996. 
VIDAL, R.A. ; THEISEN, G. Efeito da cobertura do solo sobre a mortalidade de sementes de capim-marmelada em duas profundidades de solo. Planta Daninha, v.17, p.339-344, 1999.

VOLL, E.; GAZZIERO, D.L.P.; KARAM, D. Dinâmica de população de Brachiaria plantaginea (Link.) Hitchc. sobre manejos de solo e de herbicidas. 2. Emergência. Pesquisa Agropecuária Brasileira, v.31, p.27-37, 1996.

WALLER, D.M. Factors influencing seed weight in Impatiens capensis (Balsiminaceae). American Journal of Botany, v.69, p.1470-1475, 1982.

WEIS, I.M. The effect of propagule size on germination and seedling growth in Mirabilis hirsuta. Canadian Journal of Botany, v.60, p.1868-1874, 1982.

WESTER, R.E. ; MAGRUDER, R. Effect of size, condition, and production locality on germination and seedling vigor of Baby Fordhook bush lima bean seed. Proceeding of the American Society for Horticultural Science, v.36, p.614-622, 1938.

WHITE, J.W. ; GONZÁLES, A. Characterization of the negative association between seed yield and seed size among genotypes of common bean. Field Crops Research, v.23, p.159-175, 1990.

WILBUR, H.M. Propagule size, number, and dispersion pattern in Ambystoma and Asclepias. American Naturalist, v.111, p.43-68, 1977.

WILEN, C.A.; HOLT, J.S. McCLOSKEY, W.B. Effects of soil moisture on observed and predicted yellow nutsedge (Cyperus esculentus L.) emergence. Weed Science, v.44, p.890-896, 1996a.

WILEN, C.A.; HOLT, J.S. McClOSKEY, W.B. Predicting yellow nutsedge (Cyperus esculentus) emergence using degree-day models. Weed Science, v.44, p.821-829, 1996b. 
WILLIAM, R.D. Control of purple nutsedge (Cyperus rotundus L.) and competition with vegetables. West Lafayette, 1974. p.4-26. Thesis (PhD) - Faculty of Purdue University.

WILLIAM, R.D. Photoperiodic effects on the reproductive biology of purple nutsedge (Cyperus rotundus). Weed Science, v.26, p.539-542, 1978.

WILLIAMS, R.D. Growth and reproduction of Cyperus esculentus L. and Cyperus rotundus L. Weed Research, v.22, p.149-154, 1982.

WILLIAMS, R.D.; QUIMBY JUNIOR, P.C.; FRICK, K.E. Intraspecific competition of purple nutsedge (Cyperus rotundus) under greenhouse conditions. Weed Science, v.25, p.477-481, 1977.

WILLS, G.D. Sugars, phosphorus, and iron in purple nutsedge. Weed Science, v.20, p.348-350, 1972.

WILLS, G.D. Effect of light and temperature on growth of purple nutsedge. Weed Science, v.23, p.93-96, 1975.

WILLS, G.D. Description of purple and yellow nutsedge (Cyperus rotundus and $C$. esculentus). Weed Technology, v.1, p.2-9, 1987.

WILLS, G.D. ; BRISCOE, G.A. Anatomy of purple nutsedge. Weed Science, v.18, p.631-635, 1970.

WILLSON, M.E. ; PRICE, P.W. Resource limitation of fruit and seed production in some Asclepias species. Canadian Journal of Botany, v.58, p.2229-2233, 1980.

WULFF, R.D. Seed size variation in Desmodium paniculatum. I. Factors affecting seed size. Journal of Ecology, v.74, p.87-97, 1986a.

WULFF, R.D. Seed size variation in Desmodium paniculatum. II. Effects on seedling growth and physiological performance. Journal of Ecology, v.74, p.99-114, 1986b. 
ZANDSTRA, B.H. ; NISHIMOTO, R.K. Movement and activity of glyphosate in purple nutsedge. Weed Science, v.25, p.268-274, 1977. 